\title{
THE COMMUNITY REINVESTMENT ACT RECONSIDERED
}

\section{A. BROOKE OVERBY†}

CRA has been in force for 15 years. Presumably more than enough time to work out any procedural or process problems. Regrettably, that does not appear to have been the case. It seems that we are still struggling with the basics of implementing this law properly. ${ }^{1}$

\section{INTRODUCTION}

The next few years will bring significant development in banking law. Ever since its enactment in 1977, the Community Reinvestment Act (the CRA or the Act), ${ }^{2}$ a seemingly modest piece of legislation intended to motivate certain financial institutions to meet community credit needs, has been the focus of intense criticism within the financial community. As Senator Cranston's statement indicates, much of the debate has centered upon the very basic issue of how to enforce the Act properly. Regulators' enforcement efforts evoked consternation from the financial institutions regulated under the Act, ${ }^{3}$ the community groups representing the intended beneficiaries of the Act, ${ }^{4}$ and even from Congress itself. ${ }^{5}$ The regulators'

† Associate Professor of Law, Tulane University School of Law. I would like to thank Lloyd Bonfield, Kirsten Engel, John Kramer, Bill Lovett, and Peter Swire for their comments on earlier drafts of this Article, and to John McAusland and Heather McDougald for their research assistance. Special thanks go to Joel Friedman and Heather McDougald.

${ }^{1}$ Current Status of the Community Reinvestment Act: Hearing Before the Subcomm. on Housing and Urban Affairs of the Senate Comm. on Banking, Housing, and Urban Affairs, 102d Cong., 2d Sess. 2 (1992) [hereinafter 1992 Senate Hearings] (statement of Sen. Cranston).

${ }^{2} 12$ U.S.C. $\$ \S 2901-2907$ (1988 \& Supp. V 1993).

${ }^{3}$ See, e.g., John C. Foreman \& J. McDuffie Brunson, CRA: Bankers on the Defensive, BANK MGMT., Jan. 1991, at 34 (discussing bankers' anxiety, frustration, and uncertainty in response to CRA enforcement).

+ See 1992 Senate Hearings, supra note 1, at 11 (statement of Michael Bodaken, Community Reinvestment Coordinator, Office of Mayor Tom Bradley, L.A., Cal.) (stating that regulators evaluate too leniently); $i d$. at 34-36 (statement of Calvin Bradford, President, Community Reinvestment Associates, Des Plaines, Ill.) (stating that the CRA leads to inefficiency and excessive paperwork); id. at 97 (testimony of Gilda Haas, Communities for Accountable Reinvestment) (concluding that "for the most part, neither banks nor regulators have yet delivered the promise of the [CRA]").

5 See 1 STAFF OF SENATE CoMm. ON BANKING, HOUSING, AND URBAN AFFaIRS 102D CONG., 2D SESS., REPORT ON THE STATUS OF THE COMMUNITY REINVESTMENT ACT 1-6 
response to these charges was one of frustration. The Act contains little more than the scant directive that agencies "encourage ${ }^{n 6}$ the institutions they supervise to meet community credit needs, and that they should take the institutions' performances in meeting those needs "into account" when evaluating applications to the agency. ${ }^{7}$ Given these bare legislative mandates, the agencies' perceptions of being caught in the maelstrom of the CRA debate ${ }^{8}$ with no ability to extract themselves are palpable.

The most recent endeavor to break this deadlock over CRA enforcement has, not surprisingly, come up short in spite of nearly two years of public debate. In July of 1993, President Clinton gave regulators their "marching orders" ${ }^{\text {" }}$ when he instructed financial institution regulators to develop new regulations to enforce the CRA. ${ }^{10}$ After a series of well-publicized public hearings held across

(Comm. Print 1992) [hereinafter SENATE PRINT] (describing how the CRA's goals have not been met even though a majority of banks have been receiving satisfactory or better ratings); see also Effective Implementation of the Community Reinvestment Act: Hearing Before the Subcomm. on General Oversight, Investigations, and the Resolution of Failed Financial Institutions of the House Comm. on Banking, Finance and Urban Affairs, 103d Cong., Ist Sess. 1-4 (1993) (statement of Chairman Flake) (summarizing how the CRA has failed to achieve its goal of preventing redlining); 1992 Senate Hearings, supra note 1, at 2-3 (statement of Sen. Cranston) (describing the inadequacy of CRA evaluations); id. at 19 (statement of Sen. Sasser) (stating that "despite CRA's passage, lending patterns still reflect discrimination against certain communities and certain ethnic groups"); Community Reinvestment Act: Hearings Before the Senate Comm. on Banking, Housing and Urban Affairs, 100th Cong., 2d Sess. 7-8 (1988) [hereinafter 1988 Senate Hearings] (opening statement of Chairman Proxmire) (criticizing regulators' enforcement efforts to date).

6 12 U.S.C. $\$ 2901(\mathrm{~b})$.

${ }^{7} \S 2903(2)$.

${ }^{8}$ See, e.g., Statement of Lawrence B. Lindsey, Member, Board of Governors of the Fed. Reserve Sys., Before the Subcomm. on Consumer Credit and Ins. of the House Comm. on Banking, Fin. and Urban Affairs, 79 Fed. Res. Bull. 285, 285 (1993) (explaining that regulators are "caught in the middle" and "receive brickbats from all sides"); William M. Isaac, Comment: Reform of CRA Ought to Be Guided by Its Original Purpose, AM. BANKER, Mar. 30, 1994, at 16 (statement of former FDIC chair) (explaining that "regulators ... were caught in the middle").

${ }^{9}$ Lawrence Lindsey, Presiding Member, Board of Governors of the Fed. Reserve Sys., Opening Remarks at the Public Meeting Regarding Ideas on Community Reinvestment Act Reform Before the Board of Governors of the Fed. Reserve Sys. 5 (Aug. 25, 1993) (transcript on file with author).

${ }_{10}$ President Clinton's directive to alter the CRA enforcement apparatus was accompanied by a bill to establish funding for community development financial institutions. See infra text accompanying notes 402-06. Clinton campaigned on a promise to strengthen the CRA and to enhance community development lending programs. See, e.g., Bill Clinton \& Al Gore, Putting PeOPle First 12 (1992) (promising to " $[\mathrm{e}]$ ase the credit crunch in our inner cities by passing a more progressive [CRA] to prevent redlining, and by requiring financial institutions to invest in 
the country, ${ }^{11}$ in December of 1993 regulators released for comment a proposed CRA enforcement scheme that would have constituted a significant shift in CRA policy. ${ }^{12}$ Most significantly, the proposals attempted to respond to industry complaints that the existing enforcement regime provided ambiguous performance standards and excessive paperwork, as well as to activists' and politicians' concerns that the existing CRA regime "overemphasize[d] process and underemphasize[d] performance." ${ }^{13}$ The December 1993 proposals set forth quantifiable performance criteria to be used in assessing whether an institution was meeting community credit needs and established an evaluation system that sought to reward results in community lending over an institution's efforts to meet credit needs. ${ }^{14}$ While under the old CRA regime a gallant attempt to meet community credit needs might have warranted an outstanding grade under the CRA, under the proposed regulations, an institution would have to demonstrate that its efforts produced quantifiable results-loans actually made to communities.

The December attempt to combine reduced regulatory burden with verifiable results predictably sparked an extreme reaction from all sides. ${ }^{15}$ It was not until October of 1994 that regulators published for comment a revised set of CRA enforcement regulations that modified considerably their December proposal, yet retained the emphasis on results rather than efforts. ${ }^{16}$ While

their communities").

"See Community Reinvestment Act Regulations, 58 Fed. Reg. 67,466, 67,467 (1993) (proposed Dec. 21, 1993) [hereinafter December 1993 Proposed Regulations] (stating that " $[t]$ o implement the President's initiative, the four agencies held a series of seven public hearings across the country").

${ }^{12}$ See id. at 67,466 ("The proposed procedures are designed to emphasize performance rather than process ..... $)$.

${ }^{13} \mathrm{Id}$. at 67,467 .

14 See id. at 67,468. The most controversial provision of the December 1993 proposal was the market share component of the December 1993 Lending Test, which required regulators to give predominant consideration to an institution's market share of loans in low- and moderate-income geographies, as well as to wealthier geographies. See id. at 67,487 . In effect, this test leaned dangerously close to complete government oversight of the local market for credit and was modified significantly in the October proposals. See Community Reinvestment Act Regulations, 59 Fed. Reg. 51,232, 51,237 (1994) (proposed Oct. 7, 1994) (discussing comments on the market share component and reasons for modifying the Lending Test).

${ }^{15}$ Regulators received over 6700 comments on the December proposal from the financial industry, consumer interest groups, governmental entities, and other interested parties. See Community Reinvestment Act Regulations, 59 Fed. Reg. $51,232,51,233-34$.

${ }^{16}$ See id. at 51,234 (stating that "the revised proposal would further emphasize the 
regulators reviewed the onslaught of comments on that proposal and ultimately, in late April of 1995, approved the final enforcement regulations, ${ }^{17}$ Congress began a concerted effort to forestall or undercut the effectiveness of any final rules. ${ }^{18}$

The intensity of the response to the regulators' proposals, and the lengthy as well as highly contentious process that has surrounded the CRA revision efforts, indicates that the CRA is certain to engender continued objection. Some regulators have questioned whether a results-based CRA would lead us dangerously close to credit allocation, ${ }^{19}$ a policy that is expressly rejected in the legislative history of the CRA. ${ }^{20}$ Larger institutions have objected to the paperwork burden and compliance costs of the CRA, and have questioned whether some of the proposals increased rather than reduced those costs. ${ }^{21}$ Yet, less stringent reporting and performance criteria for smaller institutions have evoked objections from community activist groups. ${ }^{22}$ On the legislative side, the stream of

institution's performance with respect to low- and moderate-income individuals").

${ }^{17}$ See Community Reinvestment Act Regulations, 60 Fed. Reg. 22,156 (1995) (to be codified in scattered sections of 12 C.F.R.) (joint final rules); see also Industry Attacks New Reporting and Enforcement Sanctions in CRA Proposal, BANKING POL'Y REP., Dec. 19, 1994, at 4 (delineating the banking industry's objections to October proposal).

${ }^{18}$ Congress's move against the revision effort had both informal and formal components. Informally, the House by letter requested regulators to delay any final changes until hearings first could be held on CRA reform. See Barbara A. Rehm, House Panel, Eyeing Hearings, Seeks a Delay in CRA Reform, AM. BANKER, Jan. 19, 1995, at 2. In addition, formal bills were introduced in the House and Senate placing a moratorium on new regulations, which may or may not block the new CRA rules. See Barbara A. Rehm, Moratorium on Regulation May Hit Banks: Exemptions Sought for Key Proposals, AM. BANKER, Jan. 13, 1995, at 1. Finally, a number of bills have proposed substantial modifications to the CRA. See, e.g., S. 650, 104th Cong., 1st Sess. $\$ \S 131$ 135, 231 (1995) (proposing numerous amendments to the CRA and prohibiting any additional reporting requirements), available in LEXIS, Legis library, Bills file; H.R. 1362, 104th Cong., 1st Sess. $\$ \$ 121-129$ (1995) (same), available in LEXIS, Legis library, Bills file.

${ }^{19}$ See Claudia Cummins, Fed Criticizes Clinton Plan on Overhaul of the CRA, AM. BANKER, Dec. 13,1993, at 1, 3 ("'We are not only contemplating credit allocation, we are contemplating resource allocation.'" (quoting John P. LaWare, Member, Board of Governors of the Fed. Reserve Sys.)).

${ }^{20}$ See infra text accompanying notes 106-11 (discussing congressional reactions to the CRA).

${ }^{21}$ See, e.g., Cummins, supra note 19, at 3 (explaining that some federal governors are concerned over data collection costs); Claudia Cummins, U.S.: Vary CRA Rules for Big, Small Banks, AM. BANKER, Dec. 9, 1993, at 1, 3 (quoting Donald Ogilvie of the American Bankers Association (ABA) as saying that the ABA has "some serious concerns about added data collection requirements").

${ }^{22}$ See Claudia Cummins, CRA Overhaul Set for Unveiling This Week, AM. BANkER, 
bills proposing modifications to the CRA shows no sign of abating. ${ }^{23}$ Finally, financial service providers not currently subject to the mandates of the CRA have stepped up lobbying efforts to ensure that they too will not become caught in the CRA's often ineluctable grasp. ${ }^{24}$

It accordingly appears that the most recent experience in developing a new CRA enforcement mechanism reinforces the proposition that, with respect to the GRA, only two planes of agreement exist. Certainly everyone shares the vision to which the Act's inspirational name- “community reinvestment"-alludes. That our communities merit investment is a point beyond question. Beyond such lofty truisms lies an agreement to disagree. We know that we care, but controversy arises as to why we do-and how to go about making the vision a reality. With respect to the CRA itself, the precise issue is how far to intervene in the private lending decisions of financial institutions to accomplish the goal.

The debate to date over the scope of such intervention has fallen into two sharply divergent camps. On the one hand, the CRA has been identified by some as a crucial step toward, if not a key to, solving the problems of inadequate housing, urban decay, and violence that have become issues of national importance. ${ }^{25}$ In

Dec. 6, 1993, at 3 (explaining that activists oppose the less stringent requirements for small banks, and estimating that $80 \%$ of banks will be able to receive easier treatment).

${ }^{23}$ See, e.g., supra note 18 (citing recent legislative initiatives); infra note 378 (citing various proposals for CRA modifications).

${ }^{24}$ See, e.g., James B. Arndorfer, Industry Gets a Chill over CRA Compliance, AM. BANKER, Sept. 3, 1993, at 8 (stating that credit unions would oppose amending the CRA to apply to them); BankAmerica's Arguments for Putting Nonbanks Under CRA, AM. BANKER, Sept. 28, 1993, at 12 (asserting that the entire financial service industry, including mutual funds, should be included under the CRA's "big tent"); Karen Gullo, Finance Companies Gear up to Ward off CRA Regulation, AM. BANKER, Dec. 22, 1993, at 4 (proclaiming that finance companies are "gearing up for battle" to avoid being subject to the CRA); Edward Kulkosky, Activists Say Study Supports Call for Applying CRA to Nonbanks, AM. BANKER, Mar. 9, 1994, at 10 (explaining a Woodstock Institute study, which suggested that mortgage companies should fall within the CRA's scope); Snigdha Prakash, Rep. Kennedy Boosts Pressure to Put CRA on Mortgage Lenders, AM. BANKER, Sept. 29, 1994, at 10 (describing the position of Stephen Ashley, president of the Mortgage Bankers Association, who "said he thought mortgage banks could go out of business, if their loans in targeted areas did not meet the underwriting criteria of Fannie Mae and Freddie Mac," when asked what bad consequences he foresaw if a CRA law were applied to mortgage bankers).

${ }^{25}$ See, e.g., 1992 Senate Hearings, supra note 1, at 3 (statement of Sen. Cranston) (claiming that the "CRA is arguably the most important federal tool for increasing private lending in the inner cities"). The 1992 riots in South Central Los Angeles heightened congressional concern with community disinvestment and stricter enforce- 
their view, only the lax effort of regulators to enforce the CRA. has undercut materialization of this appealing end. Yet, the movement toward more aggressive intervention through heavy-handed enforcement has not by any stretch received universal acclaim. At the other extreme, the Act's interference with the otherwise private market for credit is more controversial as a matter of banking law. That the Act seems to compel suboptimal lending patterns ${ }^{26}$ impels some commentators swiftly to the conclusion that the CRA is questionable social policy ${ }^{27}$ or "fundamentally flawed . . . anachronistic and ultimately self-defeating." 28

The irreconcilable nature of these extremes in the dialogue over community investment and the CRA indicates that the problems that have arisen with respect to the CRA since its enactment do not devolve from some minor and ultimately resolvable disagreement over "enforcement." Yet, this is how we have talked about the CRA to date. Enforcement of what and why-toward what end? The rhetoric of enforcement unfortunately has concealed the much

ment of the CRA:

We saw clearly in Los Angeles . . . what can happen when a community that has been systematically disinvested erupts in rage and frustration. While Los Angeles must be the most prominent example we have, similar problems exist in virtually every major metropolitan area in the country. ... Access to capital for home ownership, small business, and economic development is even more critical if distressed urban neighborhoods are to be revitalized.

Id. at 1-2; see also Provision on Financial Services to Cities Affected by Civil Disturbances, 78 Fed. Res. Bull. 532, 532 (1992) (Federal Reserve Board Announcement in response to Los Angeles riots) (stating that the Federal Reserve would "tak[e] into account investment in the affected areas by state member banks located outside those areas when assessing [CRA] performance and evaluating applications submitted to the Federal Reserve"); Peter Dreier, America's Urban Crisis: Symptoms, Causes, Solutions, 71 N.C. L. REV. 1351, 1396 (1993) (explaining that the CRA has played an important role in neighborhood revitalization efforts despite lack of enforcement). A recent legislative proposal would expand the CRA to encompass an institution's historic preservation efforts. See H.R. 3683, 103d Cong., 1st Sess. (1993). Another proposal supports CRA activities "that help to fight the causes of violence and to prevent crime." S. Res. 163, 103d Cong., 1st Sess. (1993).

${ }^{26}$ See William C. Gruben et al., Imperfect Information and the Community Reinvestment Act, FED. RESERVE BANK OF S.F. ECON. Rev., Summer 1990, at 27, 41 (describing how the CRA interferes with what otherwise might be optimal lending patterns).

${ }^{27}$ See Geoffrey P. Miller, Legal Restrictions on Bank Consolidation: An Economic Analysis, 77 IOWA L. REv. 1083, 1111 (1992) ("Whatever the merit of the CRA itself ... it is dubious social policy . . . ."). See generally Jonathan R. Macey \& Geoffrey P. Miller, The Community Reinvestment Act: An Economic Analysis, 79 VA. L. REV. 291 (1993) (offering a broad economic critique of the CRA).

${ }^{28}$ Lawrence J. White, The Community Reinvestment Act: Good Intentions Headed in the Wrong Direction, 20 FORDHAM URB. L.J. 281, 282 (1993). 
more fundamental and primary concern of what obligations financial institutions should have to their communities, and to the individuals that constitute those communities. Accordingly, the future of the CRA requires not just learning how to enforce the law properly, but more importantly how to conceptualize and construct the essential ethos of the financial institution.

This Article disengages the CRA from the more superficial debate of enforcement and instead analyzes it within the context of this more fundamental question of the character of financial institutions. The Article argues that, in spite of the Act's name, talk of "community" is the CRA's principal ambiguity, and one that has provided the major obstacle to effectuation of the Act's purpose. The CRA's implication that banks and other institutions regulated under the Act should owe some special duty toward their local communities provides the nexus for the debate over community. The economic soul of such institutions leads some to reject wholesale the CRA and, with it, such duties. ${ }^{29}$ In contrast, some suggest that the success of the CRA should be assessed under and critiqued by a communitarian paradigm, if not a communitarian agenda, for financial institution regulation. ${ }^{30}$ Implicit in this communitarian position is the proposition that banks and other financial institutions are not-and should not be-merely objective economic actors responding to market forces, but rather should be active, and good, community citizens. Such radically divergent positions on community, financial rationality, and institutional citizenship explain the CRA's lack of success to date. Unfortunately, it appears that the Act will continue to fall short of its potential as long as the dialogue about the CRA is oriented around the concept

${ }^{29}$ See Macey \& Miller, supra note 27, at 294 (noting that "the CRA in its present form does more harm than good").

${ }^{30}$ See Anthony D. Taibi, Banking, Finance, and Community Economic Empowerment: Structural Economic Theory, Procedural Civil Rights, and Substantive Racial Justice, 107 HARV. L. REv. 1463, 1470-71 (1994) [hereinafter Taibi, Communily Economic Empowerment] (noting that "[a] review and critique of the CRA's successes and failures can more effectively improve people's lives and create a multi-racial political consensus than can current paradigms"); Anthony D. Taibi, Race Consciousness, Communilarianism, and Banking Regulation, 1992 U. ILL. L. REv. 1103, 1114-16 n.46, 1116 [hereinafter Taibi, Communilarianism and Banking Regulation] (discussing banking regulation from the perspective of "community empowerment" as well as of civil rights issues). Taibi criticizes the CRA for not going beyond procedural fairness and argues that banking regulations should ensure that an appropriate lending level is actually attained in all communities. See Taibi, Community Economic Empowerment, supra, at 1484-515. 
of "community." Neither side in the battle will be completely satisfied with the changes in CRA enforcement, and the CRA debate can be expected to continue to rage, despite regulators' most recent efforts to enhance enforcement of the Act. The underlying problems that the CRA was intended to address, however, will remain unresolved. That we fiddle about community while the war against poverty is being lost may be just politics, but it is not inevitable, and certainly not ideal.

If talk of community is the CRA's fundamental error, the question becomes what remains of the CRA once the community has been excised from "community reinvestment." While this Article argues that the Act has little, if anything, to do with "community," it does not advocate repeal of the CRA. Rather, this Article posits that individual equality, rather than community, constitutes the best underlying justification for some sort of CRAtype intervention into the affairs of financial institutions. Once the GRA is moved into equality's realm, remodelling the scope of legislative intervention and regulatory enforcement can occur. This Article proposes that equality of access and equality of opportunity should be the guiding justifications for assessing the proper scope of intervention through the CRA. Applying these principles, a limited intervention into the affairs of financial institutions through the CRA is mandated. Most significantly, it will be argued that the efforts-based regulatory enforcement regime that resulted in such intense criticism was at base the proper approach to CRA enforcement and that the new results-based enforcement regime urged upon regulators by community groups and the Clinton administration is, unless carefully implemented and enforced, misguided. ${ }^{31}$ In short, despite the incessant dialogue over proper enforcement, regulators had in fact been getting the CRA largely right all along, if only instinctively, in equality's name.

Part I of this Article addresses in detail the unfortunate development of the CRA to date. The debate over proper enforcement is discussed more fully in the context of the legislative history of the CRA and of the efforts of regulators to devise a means to enforce the Act. Part II describes the communitarian and anticommunity economic views on the CRA and argues that each view fails to provide a convincing justification for intervention or nonintervention. Part II then develops more fully the individual

${ }^{31}$ See infra text accompanying notes 334-48. 
equality underpinnings of the CRA. Part III critiques the most recent effort to strengthen CRA enforcement. Finally, the equality perspective on the CRA suggests a framework both for interpreting the new CRA regulatory enforcement regime as well as for advancing other legislative and regulatory initiatives that, although not necessarily a proper subject of the CRA, will advance us toward the goals that the CRA envisions. Part IV accordingly advances these specific proposals for reform.

\section{Text, Implementation, AND the SeArch for a Purpose}

The intensity of the debate generated by the CRA evidences that the path toward the vision of community investment has been a difficult and largely unsuccessful one. Close examination of the legislative history of the Act will show that, perhaps, that result was preordained from the start. The CRA was the product of largely unreflective congressional debate as to the Act's purpose. In addition, regulators' attitudes toward enforcing the Act have been, charitably, widely vacillating since its enactment.

Yet, the actual statute giving rise to the controversy over community investment issues has a textual modesty that innocently belies the contentiousness it has spawned. The Act begins with congressional findings that regulated institutions are required to demonstrate that their deposit facilities meet the convenience and needs of the communities, that a community's convenience and needs include credit needs in addition to deposit needs, and that regulated institutions have a "continuing and affirmative obligation to help meet the credit needs of the local communities in which they are chartered." 32 The CRA's stated purpose is to require the federal financial supervisory agencies ${ }^{33}$ to use their authority to "encourage" regulated institutions ${ }^{34}$ "to help meet the credit needs

3212 U.S.C. $\S 2901$ (a)(3).

${ }^{33}$ The agency responsible for examining national banks is the Comptroller of the Currency; for federally insured savings banks and savings and loans the agency is the Office of Thrift Supervision; for state member banks it is the Federal Reserve; and for federally insured state nonmember banks it is the Federal Deposit Insurance Corporation. See § 2902(1)(A)-(D).

${ }^{34}$ "Regulated financial institutions" are insured depository institutions as defined in the Federal Deposit Insurance Company Act (FDICA). § 2902(2). In short, any depository institution-including national banks and state banks, trust companies, savings banks, industrial banks, and other banking institutions-insured by the Federal Deposit Insurance Corporation is subject to the CRA. See 12 U.S.C. \$ 1813(a)-(c) (Supp. V 1993) (FDICA definitions). This leaves institutions such as mutual funds, pension funds, insurance companies, and uninsured mortgage companies or brokers 
of the local communities ... consistent with the safe and sound operation of such institutions." 35

Despite the Act's broad findings and purposes, the CRA is studiously vague as to enforcement. A regulated institution's supervisory agency is to "assess the institution's record of meeting the credit needs of its entire community, including low- and moderate-income neighborhoods, consistent with the safe and sound operation of such institution. ${ }^{n 6}$ The agency must complete a written evaluation of the institution's CRA performance; this evaluation will have both a public part and a confidential part. ${ }^{37}$ Amendments to the Act in 1989 require the agency to rate the institution's performance using one of four possible grades, ${ }^{38}$ and require public disclosure of the public section of the institution's CRA report. ${ }^{39}$ The Act requires an institution's CRA performance to be "tak[en] into account" when its supervisory agency evaluates applications related to charters, deposit insurance, branches, and

beyond the scope of the Act.

${ }^{35} 12$ U.S.C. $\$ 2901$ (b).

${ }^{36} \S 2903(\mathrm{a})(1)$.

${ }^{37}$ See $\$ 2906$. The confidential portion contains names of individuals who have supplied information to the agency in connection with the agency's examination of the institution and statements obtained or made by the agency that the agency deems too sensitive or speculative to release to the public or to the financial institution. See $\$ 2906(c)(1)-(2)$. Other than with respect to the names of persons supplying information, the confidential portion of the CRA evaluation can be disclosed in whole or part to the institution (but not the public) if the agency determines that disclosure would promote the institution's compliance with the CRA. See $\S 2906$ (c)(3).

${ }^{38}$ The four possible ratings are: (1) Outstanding, (2) Satisfactory, (3) Needs to Improve, and (4) Substantial Noncompliance. See $\$ 2906(b)(2)$. The four-tier rating system replaced a five-tier numerical rating system developed and employed by regulators after enactment of the CRA in 1977. See H.R. CONF. REP. NO. 222, 101st Cong., Ist Sess. 460 (1989), reprinted in 1989 U.S.C.C.A.N. 432, 499.

Amendments in 1994 require agencies to evaluate institutions with interstate branches both on the entire institution's performance as well as on a state-by-state branch basis. See Riegle-Neal Interstate Banking and Branching Efficiency Act of 1994, Pub. L. No. 103-328, sec. 110 (a), 108 Stat. 2338, 2364 (1994) (to be codified at 12 U.S.C. $\$ 2906(\mathrm{~d})-(\mathrm{e}))$.

${ }^{\text {s9 }}$ See 12 U.S.C. $\$ 2906$. The public section of an institution's CRA report must contain the supervisory agency's conclusions for each regulatory assessment factor, the facts and data supporting those conclusions, and the institution's rating and a statement of the basis for the rating. See $\$ 2906(b)(1)(A)-(C)$. Minor amendments to $\$ 2906(b)(1)$ were enacted in late 1994. See Riegle-Neal Interstate Banking and Branching Efficiency Act, $\S 110(\mathrm{~b})$. For a discussion of the evolution of the rating procedure used by a supervisory agency, see infra text accompanying notes 134-45. 
mergers or acquisitions. ${ }^{40}$ Finally, the Act instructs the regulatory. agencies to publish regulations for enforcement of the CRA. ${ }^{41}$

The only palpable performance criteria in the text of the statute-other than the ineluctable directive that institutions are expected to meet community credit needs-arrived in $1991^{42}$ and 1992.43 In its first reference to race and gender, the Act was amended in 1991 to provide that when evaluating an institution's performance in meeting community credit needs, consideration should be given to any loss or contribution incurred when an institution donates, sells on favorable terms, or makes available on a rent-free basis a branch located in a predominantly minority neighborhood to a minority depository institution or a women's depository institution. ${ }^{44}$ In 1992, agencies were instructed to consider in the CRA evaluation process majority-owned institutions' capital investment, loan participation, and other cooperative ventures with minority-owned and female-owned financial institutions and low-income credit unions. ${ }^{45}$ Of course, such activities

${ }^{10} 12$ U.S.C. $\$ 2903(\mathrm{a})(2)$. The applications that invoke agency consideration of the institution's CRA record are: (1) applications for a national bank or federal savings and loan charter; (2) applications for deposit insurance for a newly chartered state bank, savings and loan, or similar institution; (3) applications to establish a domestic branch; (4) applications to relocate a home office or a branch office; (5) applications for mergers, consolidations, asset acquisitions, or liability assumptions that otherwise require regulatory approval; and (6) applications to acquire shares in, or assets of, a regulated institution that otherwise require regulatory approval. See $\S 2902(3)$.

${ }^{11}$ See $\$ 2905$.

12 See Resolution Trust Corporation Refinancing, Restructuring, and Improvement Act of 1991, Pub. L. No. 102-233, § 402(b), 1991 U.S.C.C.A.N. (105 Stat.) 1761, 1775 [hereinafter RTCRRIA] (codified at 12 U.S.C. $\$ 2907$ (Supp. V 1993)).

${ }^{13}$ See Housing and Community Development Act of 1992, Pub. L. No. 102-550, $\S 909,1992$ U.S.C.C.A.N. (106 Stat.) 3672, 3874 [hereinafter HCDA] (codified at 12 U.S.C. $\$ \S 2903,2907$ (Supp. V 1993)).

44 See 12 U.S.C. \$ 2907. "Minority institutions" are those institutions "more than $50 \%$ of the ownership or control of which is held by [one] or more minority individuals; and ... more than $50 \%$ of the net profit or loss of which accrues to [one] or more minority individuals." $\S 2907(b)(1)$. "Women's depository institutions" are those in which at least $50 \%$ of the ownership or control in the institution is held by one or more women, in which more than $50 \%$ of the institution's net profit or loss accrues to one or more women, and in which women held a significant percentage of senior management positions. $\S 2907(b)(2)$.

Originally $\S 2907$ provided that covered minority investments "shall be treated as" a factor in CRA performance. RTCRRIA, $\$ 402$ (b), 1991 U.S.C.C.A.N. (105 Stat.) at 1775 . The next year, however, the section was amended to provide only that such activities "may be a factor." HCDA, § 909(2), 1992 U.S.C.C.A.N. (106 Stat.) at 3874.

${ }^{45}$ See 12 U.S.C. § 2903(b). 
must meet the underlying purpose of serving community credit needs in order to merit consideration in the evaluative process. ${ }^{46}$

In sum, the CRA is comprised of a succinct ${ }^{47}$ recognition that a community's financial needs include credit as well as deposit needs, a purpose of "encouraging" institutions to meet those credit needs, and finally a directive that an institution's CRA performance be one aspect of the examination as well as a factor to be "taken into account" when assessing the institution's applications for new or expanded privileges. Yet, the Act's simplicity is deceptive and its apparently innocuous recognition of the "need" for credit is in fact politically, economically, and morally significant. Even if credit and capital are resources that bear sufficient import to merit legislative attention, serious institutional considerations arise from the CRA's intervention into the affairs of private lending institutions to facilitate the availability of credit. Credit may have a normative dimension, but isolating only particular private institutions to provide credit to communities and to bear the costs of that endeavor, as the CRA does, raises equally troubling concerns. Missing from the Act is any justification for the CRA or indication of why only particular institutions were selected to perform the CRA's task of meeting community credit needs.

These deficiencies have caused some to question critically the propriety of the Act. A recent critique of the CRA, by Professors Jonathan Macey and Geoffrey Miller, ${ }^{48}$ argues that the Act suffers from a myriad of potential shortcomings. ${ }^{49}$ Macey and Miller note that the Act results in a differential impact on depository institutions, ${ }^{50}$ potentially negative effects on the safety and soundness of

${ }^{46}$ See id.

${ }^{47}$ The remaining provisions of the Act involve relatively minor issues. See, e.g., $\$ 2902$ (definitional section); $\$ 2904$ (requiring agencies to report annually to Congress on actions taken under the CRA).

${ }^{48}$ See Macey \& Miller, supra note 27 , at 295 (noting that the Act has been turned to purposes for which it was poorly designed and has become a tool of activist political pressure groups). Although the critique addressed the original enforcement regime, most of its fundamental points would remain germane to the new enforcement regime.

${ }^{49}$ The conclusions drawn by Professors Macey and Miller are preliminary and subject to verification by further empirical research. See id. at 293-94.

${ }_{50} \mathrm{See}$ id. at 312-18. The authors point out that the CRA discriminates between institutions covered by the CRA and those not covered, in effect taxing covered financial institutions and placing them at a competitive disadvantage to those not covered. See id. at 312-13; see also infra part IV.B.2. (advancing a methodology for assessing scope of coverage). The CRA also has a differential impact among covered institutions. See Macey \& Miller, supra note 27, at 313-18. For example, an institution 
covered institutions, ${ }^{51}$ enormous compliance costs, ${ }^{52}$ and uncertain compliance standards. ${ }^{53}$ With respect to the cost of the statute, the CRA can be interpreted as a tax on covered financial institutions and their expansion. This tax is comprised not only of institutional compliance costs but expenses such as the costs of delay in the application process, the costs of defending a CRA protest raised against an application, and the costs of commitments that an institution might make to avoid community group protests. This tax also can include more intangible costs, such as costs incurred when an institution refrains from pursuing an acquisition because of vigorous CRA enforcement or because the CRA would force the institution to spend more on CRA activities in order to obtain regulatory approval of the acquisition.

The economic significance of this tax is intensified by the Act's tenuous proposition that financial institutions have an obligation to meet community credit needs. ${ }^{54}$ Not only does the CRA impose significant costs on lending institutions, but these costs are incurred to further a purpose that is, at best, unexplained and, at worst, wholly in error. Accordingly, under this critique the CRA has evolved into a statute "designed to serve organized interest

located within a wealthy community has a less burdensome CRA obligation than one located in a low-income area.

${ }^{51}$ See Macey \& Miller, supra note 27, at 318-24 (considering the impact of the CRA on the safety and soundness of banking institutions). Until recently, evidence as to the performance of CRA loans was largely anecdotal. See, e.g., Kenneth H. Bacon, Reaching Out: Under Strong Pressure, Banks Expand Loans for Inner-Cily Homes, WALL. ST. J., Feb. 23, 1994, at A1 (noting that the perception that poorer borrowers necessarily carry greater risks of default is changing). However, recent empirical research indicates that CRA loans are frequently as safe as, if not safer than, conventional loans. See generally THE WOODSTOck InSTITUTE AND The NATIONAL ASSOCIATION OF AFFORDABlE HOUSING LENDERS, SOUND LOANS FOR COMMUNITIES: An Analysis of the Performance of Community Reinvestment LoAns (1993) (concluding from a sample of CRA loans that single-family CRA loans had substantially lower delinquency rates than conventional loans, and multifamily CRA loans had comparable or slightly higher delinquency rates).

52 See Macey \& Miller, supra note 27, at 324-33. Nonetheless, CRA compliance costs under the old regime have been substantially less compared to the costs of complying with other financial legislation. See infra note 177.

${ }^{53}$ See Macey \& Miller, supra note 27, at 326-30 (discussing the subjectivity of CRA compliance rating standards).

${ }^{54}$ See supra text accompanying note 32 (discussing congressional findings that preface the Act); see also Macey \& Miller, supra note 27, at 303-12 (rejecting the ideology of the CRA). 
groups. ${ }^{n 55}$ Those groups include bank regulators, ${ }^{56}$ community group activists, ${ }^{57}$ minority and women's groups, ${ }^{58}$ Congress itself, ${ }^{59}$ and small businesses and small farms. ${ }^{60}$ The benefits accrue to these groups instead of to the public at large, including citizens in urban areas who were the intended beneficiaries of the CRA. ${ }^{61}$

Two points merge in the Macey and Miller critique of the CRA, which is the most comprehensive attack on the Act to date, ${ }^{62}$ and

${ }^{55}$ Macey \& Miller, supra note 27, at 337. For background regarding how the Act serves special interest agendas, see $i d$. at $337-44$.

${ }^{56}$ See id. at 342.

${ }^{57}$ See id. at 341-42.

${ }^{58} \mathrm{See}$ id. at 337-40. Professors Macey and Miller note critically the Federal Reserve Board's warm praise for an institution's participation in a program that was designed to increase the supply of credit to female-owned businesses, and another institution's donation of a house to a group promoting Chicano art, as examples of the CRA's evolution into a statute requiring "political correctness" on the part of covered institutions. See id.; see also Michael E. Schrader, Competition and Convenience: The Emerging Role of Community Reinvestment, 67 IND. L.J. 331, 347-48 (1992) (arguing that if community reinvestment's role continues to increase, a CRA record could become the measure of an institution's political correctness).

${ }^{59}$ See Macey \& Miller, supra note 27, at 343.

${ }^{60}$ See id. at 342 .

${ }^{61}$ See id. at 344 .

${ }^{62}$ For other articles on various aspects of the CRA during its many stages of development, see generally Robert C. Art, Social Responsibility in Bank Credit Decisions: The Community Reinvestment Act One Decade Later, 18 PAC. L.J. 1071 (1987) (analyzing the effects of the CRA on community groups, depository institutions, and federal supervisory agencies); Leonard Bierman et al., The Community Reinvestment Act: A Preliminary Empirical Analysis, 45 HASTINGS L.J. 383 (1994) (conducting an empirical analysis of the implementation of the CRA and evaluating how these results compare with past proposals for improving the CRA); Robert G. Boehmer, Mortgage Discrimination: Paperwork and Prohibitions Prove Insufficient-Is It Time for Simplification and Incentives?, 21 HOFSTRA L. REV. 603 (1993) (surveying the scope of the CRA and other mortgage discrimination statutes and proposing a legislative solution to address the problem of continuing mortgage discrimination); Marion A. Cowell, Jr. \& Monty D. Hagler, The Community Reinvestment Act in the Decade of Bank Consolidation, 27 WAKE FOREST L. REV. 83 (1992) (examining how the views of Congress, regulators, bankers, and community groups have shaped CRA developments); Warren L. Dennis, The Community Reinvestment Act of 1977: Defining "Convenience and Needs of the Communi$t y$ ", 95 BANKING L.J. 693 (1978) (comparing the development of performance evaluation criteria in other banking statutes with that of the CRA to understand what is expected of banks under the CRA); Steven J. Eisen \& Keith C. Dennen, The Community Reinvestment Act: The Regulators Give It a New Emphasis, 107 BANKING L.J. 334 (1990) (arguing that the CRA will have an even greater impact on the banking community in the years ahead); Allen J. Fishbein, The Community Reinvestment Act After Fifteen Years: It Works, but Strengthened Federal Enforcement Is Needed, 20 FORDHAM URB. L.J. 293 (1993) (discussing efforts by the banking industry to curb the CRA and the role that the CRA should take in the future); Peter F. Healey, $A$ Banker's Guide to the Community Reinvestment Act, 96 BANKING L.J. 705 (1979) (outlining the CRA's 
one whose relevance increases as reforms to the CRA progress. First, the negative effects of the CRA identified in the critique suggest methodological problems that have arisen in implementing and enforcing the CRA. This section will argue that the legislative history of the Act evidences deep-seated division over the Act as well as uncertainty over what the Act is intended to accomplish-and why. ${ }^{63}$ Next, the section will discuss how the regulatory search for a satisfactory enforcement mechanism for the Act has come up short, perhaps reflecting the ambiguities in the legislative history. ${ }^{64}$ Driving the disagreement over the appropriate scope of regulatory enforcement is the process/efforts versus performance/results debate. ${ }^{65}$ Even assuming that there is an obligation for financial institutions to meet community credit needs, this debate centers on

compliance requirements and explaining the actual duties imposed on banks); Richard Marsico, A Guide to Enforcing the Community Reinvestment Act, 20 FORDHAM URB. L.J. 165 (1993) (describing the existing CRA enforcement standards of the Board of Governors of the Federal Reserve System and proposing a framework for community-based organizations seeking to use the CRA to increase the credit available in their communities); Orin L. McCluskey, The Community Reinvestment Act: Is It Doing the Job?, 100 BANKING L.J. 33 (1983) (explaining that, while the CRA is not an antiredlining statute, it gives a large role to public interest groups to regulate from below rather than implementing a regulation from above approach); Schrader, supra note 58 (examining community reinvestment as a factor in the review of bank merger and acquisition requests); Peter P. Swire, Saje Harbors and a Proposal to Improve the Community Reinvestment Act, 79 VA. L. REV. 349 (1993) (proposing change in CRA enforcement to form safe harbors); Taibi, Community Economic Empowerment, supra note 30 (taking a community empowerment perspective toward the CRA and using this approach to suggest ways to reorient future civil rights efforts); Jonathan $P$. Tomes, The "Community" in the Community Reinvestment Act: A Term in Search of a Definition, 10 ANN. REv. BANKING L. 225 (1991) (examining the operation of the CRA and the changes that have made CRA compliance more critical than in the past); White, supra note 28 (arguing that increasing competition in financial services, while beneficial for consumers, undermines regulatory efforts); Mario Alvarado, Note, Revisiting the Community Reinvestment Act in an Era of Mergers and Acquisitions, 12 ANN. REV. BANKING L. 475 (1993) (detailing the history of the CRA and the initial problems with its implementation); Mollee Bennett, Comment, Resolving the Community Reinvestment Act Dilemma: Eliminating "Whites Only" Mortgage Lending While Reducing Regulatory Red Tape, 24 TEX. TECH L. REV. 1145 (1993) (focusing on the history of the CRA, the problems of its enforcement, and proposed solutions for ending discrimination); David E. Cohen, Comment, The Community Reinvestment Act-Asset or Liability?, 75 MARQ. L. REV. 599 (1992) (evaluating the boundaries of the CRA and the impact it has on the banking industry); Anne Marie Regan, Note, The Community Reinvestment Act Regulations: Another Attempt to Control Redlining, 28 CATH. U. L. REV. 635 (1979) (arguing that the CRA falls short of its goals by failing to outlaw redlining practices).

${ }^{63}$ See infra part I.A.

${ }^{4}$ See infra part I.B.

${ }^{65}$ See infra part I.B.2-3. 
whether the measure of compliance with the Act should be focused on an institution's efforts to meet community credit needs or on an institution's proof of actual success.

Yet, problems with implementing the Act would be less troubling if a defensible purpose for the Act exists. The above critique suggests a second and much more serious challenge to the CRA: that the Act from the beginning was unjustified as a matter of policy because it was grounded in an outdated "ideology of localism." ${ }^{\text {If }}$ the CRA was grounded in an ideology that, from the start, was faulty, irrespective of the problem of enforcement, it is questionable whether the CRA was justifiable legislation to begin with. Part III will address that fundamental question.

\section{A. The Problems}

\section{Redlining, Disinvestment, and Credit Discrimination}

The CRA is the youngest of a trinity of federal banking statutes enacted during a period of the 1970 s that could be deemed the pinnacle of federal consumer-related financial legislation. ${ }^{67}$ Legislative intervention was directed in general toward concerns that the financial services industry was engaging in practices of individual discrimination and geographic redlining, as well as perpetuating a situation of "community disinvestment," all of which systematically undermined the ability of persons to obtain credit on equal terms. The potentially polarizing effects of these practices ${ }^{68}$ spawned the CRA as well as the Equal Credit Opportunity Act ${ }^{69}$ and the Home Mortgage Disclosure Act, ${ }^{70}$ each directed toward creating a more level playing field in the market for credit.

Although discrimination in the residential real estate finance market has been prohibited under the Fair Housing Act since

${ }^{66}$ Macey \& Miller, supra note 27, at 303-12.

${ }^{67}$ See Ralph J. Rohner, Multiple Sources of Consumer Law and Enforcement (Or: "Still in Search of a Uniform Policy"), 9 GA. ST. U. L. REv. 881, 884-85 (1993) (discussing federal consumer credit legislation from 1968 to 1980).

${ }^{68}$ See H.R. REP. NO. 561, 94th Cong., 1st Sess. 4 (1975) ("[The practice of redlining] increasingly has served to polarize elements of our society in a manner wherein the dialogue has become entirely destructive, rather than constructive. As polarization intensifies, neighborhood decline accelerates."), reprinted in 1975 U.S.C.C.A.N. 2303, 2305-06.

${ }^{69}$ See infra text accompanying notes 72-76 (discussing the Equal Credit Opportunity Act).

${ }^{70}$ See infra text accompanying notes 77-80 (discussing the House Mortgage Disclosure Act). 
$1968,{ }^{71}$ it was not until the enactment of the Equal Credit Opportunity Act (ECOA) ${ }^{72}$ in 1974 that Congress addressed the issue of discrimination in lending. A response to substantial evidence that financial institutions were discriminating against applicants for credit on the basis of gender or marital status, ${ }^{73}$ the ECOA originally prohibited creditors from considering gender-related factors in assessing whether to grant credit. ${ }^{74}$ Amendments to the ECOA prohibiting discrimination on the basis of race, color, religion, national origin, age, receipt of public assistance benefits, or the exercise of rights under the Consumer Credit Protection $\mathrm{Act}^{75}$ followed two years later. ${ }^{76}$

${ }^{11}$ See Fair Housing Act of 1968, Pub. L. No. 90-284, § 805, 82 Stat. 81, 83-84 (codified as amended at 42 U.S.C. $\$ 3605$ (1988)). As originally enacted, the Fair Housing Act's antidiscrimination rule was vaguely worded and limited in scope. Amendments in 1988 expanded the scope of the rule to encompass virtually all financial-services-related residential real estate transactions. See generally Warren L. Dennis, The Fair Housing Act Amendments of 1988: A New Source of Lender Liability, 106 BANKING L.J. 405 (1989) (reviewing 1988 amendments to the Fair Housing Act and extension of its prohibitions).

${ }^{72}$ Equal Credit Opportunity Act, Pub. L. No. 93-495, 88 Stat. 1521 (1974) (codified as amended at 15 U.S.C. $\$ \S 1691-1691$ e (1988 \& Supp. V 1993)).

${ }^{73}$ See generally Credit Discrimination: Hearings on H.R. 14856 and 14908 Before the Subcomm. on Consumer Affairs of the House Comm. on Banking and Currency, 93d Cong., 2d Sess., pts. 1-3 (1974) [hereinafter ECOA hearings] (noting the policies of many major creditors to deny credit to creditworthy women).

74 See S. REP. No. 589, 94th Cong., 2d Sess. 2 (1976), reprinted in 1976 U.S.C.C.A.N. 403, 404.

${ }^{75}$ Consumer Credit Protection Act, 15 U.S.C. $\$ \S 1601-1693$ r (1988 \& Supp. V 1993).

${ }^{76}$ Equal Credit Opportunity Act Amendments of 1976, Pub. L. No. 94-239, 90 Stat. 255 (1976). The ECOA as amended provides in full:

(a) Activities constituting discrimination

It shall be unlawful for any creditor to discriminate against any appli-

cant, with respect to any aspect of a credit transaction-

(1) on the basis of race, color, religion, national origin, sex or marital

status, or age (provided the applicant has the capacity to contract);

(2) because all or part of the applicant's income derives from any public assistance program; or

(3) because the applicant has in good faith exercised any right under this chapter.

15 U.S.C. § 1691(a) (1988). Failure to comply may result in liability for actual and punitive damages, as well as for costs and attorneys' fees. See § 1691e.

The ECOA interjects an "antidiscrimination" requirement into a lender's decision whether to grant credit by making it unlawful for creditors to consider the prohibited characteristics when acting with regard to a credit transaction. Recognition of the antidiscrimination norm was grounded in the view that lender discrimination on the basis of gender and race not only unjustifiably impeded access of consumers to credit, but also constituted unprofitable and illogical business behavior: 
Although the ECOA's antidiscrimination rule has been in effect for over fifteen years, evidence recently compiled under the Home Mortgage Disclosure Act of 1975 (HMDA), ${ }^{77}$ the second legislative attempt to eliminate credit discrimination, suggests that the ECOA might have a limited ability to furnish redress to victims of credit discrimination. ${ }^{78}$ Data collected under the HMDA, which uses

[I]t must be established as clear national policy that no credit applicant shall be denied the credit he or she needs and wants on the basis of characteristics that have nothing to do with his or her creditworthiness. The Committee [on Banking, Housing, and Urban Affairs] readily acknowledges that irrational discrimination is not in the creditor's own best interests because it means he is losing a potentially valuable and creditworthy customer. But, despite this logical truth, the hearing record is replete with examples of refusals to extend or to continue credit arrangements for applicants falling within one or more of the categories addressed by [the ECOA].

S. REP. No. 589, supra note 74, at 3, reprinted in 1976 U.S.C.C.A.N. at 404 .

7712 U.S.C. $\$ \S 2801-2811$ (1988 \& Supp. V 1993).

${ }^{78}$ See Scott Ilgenfritz, The Failure of Private Actions as an ECOA Enforcement Tool: A Call for Active Governmental Enforcement and Statutory Reform, 36 U. FLA. L. REV. 447, 449-50 (1984) (discussing the failure of ECOA enforcement); Swire, supra note 62, at 368-69 (mentioning the limited number of ECOA suits); Taibi, Community Economic Empowerment, supra note 30, at 1474-76 (detailing the inadequate performance of the ECOA). Efforts to buttress ECOA enforcement power were aided by a 1991 amendment to the statute that requires financial institution supervisory agencies to notify the Justice Department "whenever the agency has reason to believe that 1 or more creditors has engaged in a pattern or practice of discouraging or denying applications for credit in violation [of the ECOA].” 15 U.S.C. $\$ 1691$ e(g) (Supp. V 1993). Some evidence suggests, however, that even after the 1991 amendment, "questionable practices" under the ECOA in some instances have been handled internally by the agencies rather than referred to the Department of Justice. Compare 1 SENATE PRINT, supra note 5, at 301 (letter from Sen. Alan Cranston) (questioning the FDIC's failure to report questionable practices to the Department of Justice) with id. at 302 (letter from Andrew C. Hove, Jr., FDIC Acting Chairman) (explaining this failure and agreeing to refer the matters to the Department of Justice).

A federal policy of more vigorous investigation and prosecution of ECOA violations appears to have breathed new life into the ECOA. The harbinger of this new attitude toward the ECOA was a complaint filed by the Department of Justice in 1992 against a Georgia-based savings and loan alleging, inter alia, race-based violations of the ECOA. See United States v. Decatur Fed. Sav. \& Loan Ass'n, No. 1 92-CV-2198 (N.D. Ga. filed Sept. 17, 1992), reprinted in 1 SENATE PRINT, supra note 5 , at 394-405. In a consent decree filed simultaneously with the complaint, the institution denied all of the allegations but agreed to institute extensive marketing, advertising, and outreach programs directed toward potential minority applicants. See 1 SENATE PRINT, supra note 5, at 406.

Similarly, in 1994, after the Department of Justice instituted an action against it for FHA and ECOA violations, a Maryland-based savings and loan and its mortgage company subsidiary agreed to invest $\$ 11,000,000$ in the African-American communities around Washington, D.C. and to open branches and mortgage offices in those communities. See Michelle Singletary, Chezy Chase Settles Case over Bias, WASH. POST, 
disclosure to address the problem of discrimination in lending, ${ }^{79}$ indicates that many minorities today have a statistically higher chance of having their home mortgage loan applications denied than do similarly situated whites. ${ }^{80}$ Yet, whether these statistics

Aug. 23, 1994, at A1. In effect the Chevy Chase consent decree imposed a CRA-type remedy for an ECOA violation. See, e.g., Jaret Seiberg, Fair Lending Law Seen as Tool to Enforce CRA Rules, AM. BANKER, Sept. 9, 1994, at 3 (quoting a banking industry attorney who described the Justice Department action as "using [the ECOA] as a back door" to enforce the CRA). This Article argues that such actions are consistent with the underlying antidiscriminatory purpose of the CRA. See infra part II.C (discussing equality as a prime justification for community reinvestment). Regulators' treatment of the ECOA through the CRA itself has been inconsistent. See infra note 353 and accompanying text.

79 The HMDA originally addressed the problem of geographic redlining by requiring institutions that made federally related mortgage loans to publicly disclose by census tract or ZIP code the number and dollar amount of mortgage loans originated or purchased by the institution during the fiscal year that were secured by residential real property located within the institution's standard metropolitan statistical area. See Home Mortgage Disclosure Act of 1975, Pub. L. No. 94-200, $\S \S 303-304,89$ Stat. 1124, 1125-26 (codified as amended at 12 U.S.C. $\$ \S 2802-2803$ (1988 \& Supp. V 1993)). The Financial Institutions Reform, Recovery, and Enforcement Act of 1989 (FIRREA) amended the HMDA to require institutions also to disclose "the number and dollar amount of mortgage loans and completed applications involving mortgagors or mortgage applicants grouped according to census tract, income level, racial characteristics, and gender." Financial Institutions Reform, Recovery, and Enforcement Act of 1989, Pub. L. No. 101-73, sec. 1211(a), $\S 304$ (b), 103 Stat. 183, 524 (codified at 12 U.S.C. $\$ 2803$ (b)(4) (Supp. V 1993)). The 1989 amendments to the HMDA permitted the compilation of statistics relating to a mortgage loan applicant's individual characteristics (rather than relating to a specific census tract alone). This resulted, however, in a disclosure statute directed more toward revealing patterns of individual discrimination than toward geographic redlining.

${ }^{80}$ The first report on data compiled under the amended HMDA was published in late 1991 (reflecting loan applications in 1990) and revealed a significant disparity in the rate of loan application denials that tracked race. See Glenn B. Canner \& Delores S. Smith, Home Mortgage Disclosure Act: Expanded Data on Residential Lending, 77 Fed. Res. Bull. 859, 859 (1991). While 14.4\% of white applicants had their applications for conventional home loans denied, $33.9 \%$ of black applicants, $22.4 \%$ of American Indian/Alaskan Native applicants, and 21.4\% of Hispanic applicants had their applications denied. See id. at 870 tbl. 5. The statistical disparity in denial rates on racial lines continued to exist even when the applicant's income was taken into account. See id. at 872 tbl. 6 (showing that minorities suffer higher denial rates than whites at all income levels). HMDA data released in 1992 (reflecting loan applications in 1991) and 1993 (reflecting loan applications in 1992) again showed a significant disparity in acceptance and rejection rates between whites and other minorities. See Glenn B. Canner \& Delores S. Smith, Expanded HMDA Data on Residential Lending: One Year Later, 78 Fed. Res. Bull. 801, 801 (1992) (stating that the 1991 data "continue to reflect wide differences in approval and rejection rates for minorities and whites"); Statement to Congress of Lawrence B. Lindsey, Member of the Board of Governors of the Fed. Reserve Sys., 80 Fed. Res. Bull. 10, 10-11 (1994) (concluding from 1992 data that "disparities between black and white approval and denial rates 
reflect flagrant and systematic biases or lending patterns that inevitably result from wealth disparities and incomplete or imperfect information about individual borrowers is an open question. ${ }^{81}$

While the ECOA and HMDA directly address (through prohibition and disclosure) lender discrimination based upon a borrower's individual characteristics, they only tangentially bear upon the related practices of geographic redlining and community disinvestment. The distinction between redlining and disinvestment is a subtle one, and is often ignored. Although difficult to articulate succinctly, and although a matter of some debate, one definition of redlining provides that it is "the alleged bank practice of systematically denying mortgages in certain neighborhoods because of economic conditions or racial factors not strictly related to loan loss experience." ${ }^{82}$ A crucial component of redlining under this

persist).

${ }^{81}$ See generally Peter P. Swire, The Persistent Problem of Lending Discrimination: A Law and Economics Analysis, 73 TEX. L. REv. 787 (1995) (analyzing the history of credit discrimination and using economic analysis to support the argument that discrimination persists). Publication of the 1991 HMDA report generated a well-publicized debate on the issue of discrimination in mortgage lending and a defensive response from financial institutions. See Paulette Thomas, Federal Data Detail Pervasive Racial Gap in Mortgage Lending, WALL ST.J., Mar. 31, 1992, at Al (summarizing the report's findings and presenting criticisms from some members of the lending industry). Lenders claim that the HMDA statistics, which merely reflect the overall acceptance and denial rates for home loans, do not reflect legitimate credit risk factors such as income, value of collateral, and job-switching. See id. at A10. A report by the Federal Reserve Bank of Boston, however, which extensively analyzed data from the Boston Metropolitan Statistical Area (MSA), concluded that even when objective credit risk criteria were taken into account, a "statistically significant gap" still remained between the denial rate for minority applicants and that for white applicants in that MSA. ALICIA H. MUNNELl ET AL., MORTGAGE LENDING IN BOSTON: INTERPRETING HMDA DATA 2 (Federal Reserve Bank of Boston Working Paper No. 92-7, 1992). Yet, some have argued that the Boston Fed study fails to provide persuasive support for the assertion that the HMDA data indicates invidious discrimination. See Peter Brimelow \& Leslie Spencer, The Hidden Clue, Forbes, Jan. 4, 1993, at 48, 48 (arguing that because the Boston Fed study indicates equal default rates between majority and minority applicants, application denials are based on legitimate credit risk factors).

Another recently released study supports some of the objections to the Boston Fed study. In a study of default rates on FHA mortgage loans, black borrowers were shown to have a higher likelihood of default than white borrowers. See James A. Berkovec et al., Discrimination, Default, and Loss in FHA Mortgage Lending 2 (Nov. 1994) (unpublished manuscript, on file with author). Yet, even federal officials acknowledge that this more recent study is not conclusive evidence that discrimination does not exist at all, just as the Boston Fed study is not conclusive evidence that discrimination exists and is pervasive. See Albert R. Karr, Fed Study Challenges Notion of Bias Against Minorities in Mortgage Lending, WALL ST. J., Jan. 26, 1995, at A16.

${ }^{82}$ Reinvestment: Public Deposits, CoMP. NEwSL. (Council on Mun. Performance, New York, N.Y.), Feb. 17, 1977, at 1, 1, reprinted in Community Credit Needs: Hearings 
definition, as well as others, ${ }^{83}$ is an element of intent to exclude a particular geographic area. The decision to exclude may be rational or irrational. Rational redlining may result from imperfect information concerning investment opportunities in the redlined area. Acquisition of such information would come at such a cost as to render any investment in community $X$ less preferable than investment elsewhere, resulting in intentional, but rational, exclusion of the area. ${ }^{84}$ Alternatively, the institution's decision to exclude a particular geographic area may be caused by irrational individual or geographic biases entirely unrelated to credit risk or information.

The practice of redlining, rational or irrational, is not necessarily synonymous with the problem of "community disinvestment," which can be defined as a failure of institutions to reinvest their deposits in the area from which those deposits were obtained. ${ }^{85}$ The hypothetical instance of a depository institution that has elected to invest all of its deposits in areas outside of its own community illuminates the important distinction between redlining and disinvestment. The institution's failure to reinvest in its community results in community disinvestment. ${ }^{86}$ Yet, without more, the

on S. 406 Before the Comm. on Banking, Housing, and Urban Affairs, 95th Cong., 1st Sess. 213 (1977) [hereinafter Hearings on S. 406]; see also Art, supra note 62, at 1076-83 (discussing the elements of redlining); Alane K. Sullivan \& Randall J. Pozdena, Enforcing Anti-Redlining Policy Under the Community Reinvestment Act, ECON. REv. (Federal Reserve Bank of San Francisco), Spring 1982, at 19, 24 (explaining the debate over generating an acceptable definition of redlining).

${ }^{83}$ A similar definition of redlining is: "The identification of a specific geographic area for the purpose of denying real estate loans or varying lending terms in a discriminatory pattern." REDLINING TASK FORCE, MORTGAGE BANKERS ASS'N OF AM., FINAL REPORT (1976), reprinted in Hearings on S. 406, supra note 82, at 405, 408. Another source similarly defines redlining as a "restriction of credit based on geography as such, apart from any consideration of actual creditworthiness." Richard A. Givens, The "Antiredlining" Issue: Can Banks Be Forced to Lend?, 95 BANKING L.J. 515,515 (1978) (footnote omitted).

${ }^{84}$ See, e.g., Gruben et al., supra note 26, at 28 (stating that rational redlining "occurs when banks restrict lending or are less aggressive in marketing loan products in certain neighborhoods because the costs of identifying the qualified loans are too high to be profitable"); Sullivan \& Pozdena, supra note 82, at 24 (stating that the CRA is directed against irrational rather than rational redlining).

${ }^{85}$ Nonetheless, many authors use the terms interchangeably. See Givens, supra note 83, at $516 \mathrm{n} .2$ ("'Often, disinvestment is used interchangeably with redlining.") (quoting URBan-Suburban INVESTMENT STUdy Group, Center for URban STUdies OF THE UNIV. Of ILl., REDLINING AND DISINVESTMENT AS A DISCRIMINATORY PRACTICE IN Residential MORTGage LOANS, PART II, at 4-5 (1977)); Sullivan \& Pozdena, supra note 82, at 24 (conflating "disinvestment" with "redlining").

${ }^{86}$ This assumes, of course, that the institution's deposits were obtained from that 
institution's practice is not redlining. For example, if the noncommunity investment opportunities seized by the institution are genuinely financially superior to those available in the bank's own community, or if there is no demand for credit in a particular community, it is difficult to assert that redlining has occurred rather than prudent investment judgment. In contrast, if the institution were failing to reinvest in its own community on unfounded perceptions about the credit risk of borrowers in low-income areas served by the institution (unrelated to the borrower's ability or willingness to pay or the value of the collateral) or because of informational problems, a stronger case for deeming the practice redlining arises. ${ }^{87}$

As with the problem of individual discrimination in credit decisions, redressing the effects of redlining and the problem of disinvestment has constituted a formidable task. The HMDA requirement of disclosing geographic mortgage lending patterns ${ }^{88}$ was originally intended to be "the beginning of a new policy" against redlining and disinvestment and "a new hope for our cities and our neighborhoods." 89 Recent evidence of possibly discriminatory patterns in the granting of mortgage credit, whether rational or irrational, ${ }^{90}$ raises the question whether the HMDA has attained its

community. See infra note 294 and accompanying text (discussing the findings of the ACORN Study of the linkage between deposit base and lending patterns). "Disinvestment" obviously cannot occur without the initial investment of members of the community through deposits.

${ }^{87}$ This is not to say that redlining may not in some instances be causally linked to the occurrence of disinvestment. Assume that the institution above had previously engaged in the practice of irrationally redlining certain low-income areas served by it. One result of the institution's practice of failing to meet the needs of creditworthy customers within the redlined area might be the area's decline as an economically unsatisfactory area in which to invest. For example, real estate collateral might have declined in value or income levels slipped further due to lack of development in the area. Cf. 123 CONG. REC. 17,633 (1977) (statement of Sen. Tower) ("The problem with most neighborhoods which have been redlined is that not only has adequate mortgage credit not been available, but a number of other necessary services are also lacking."). Even after the institution has abandoned its practice of redlining, a situation of disinvestment might still exist. Disinvestment therefore in some instances might result from a prior practice of redlining.

${ }_{88}^{8}$ See supra note 79 and accompanying text.

${ }^{89}$ H.R. REP. NO. 561, supra note 68, at 11, reprinted in 1975 U.S.C.C.A.N. at 2313. Congress's rationale for selecting disclosure as the mechanism for implementing this policy was that disclosure would facilitate identification of the areas in which redlining and disinvestment were occurring and would inform local residents as to the occurrence of those practices, thereby expediting public involvement in developing reinvestment strategies. See id. at 14-15, reprinted in 1975 U.S.C.C.A.N. at 2315-16.

${ }^{90}$ See supra note 80 and accompanying text (discussing recent evidence of 
stated goal of ending the practice of redlining. ${ }^{91}$ Similarly, such evidence indicates the inefficacy of the ECOA to date. Rather, the linchpin in the effort to ameliorate the problems of discrimination, redlining, and disinvestment was considered to be the CRA.

\section{The CRA Debate}

Some consensus has emerged that the CRA was intended to be a remedy for the problem of redlining. ${ }^{92}$ The definitional flexibility of the term "redlining, ${ }^{, 93}$ however, renders such an articulation of purpose, at best, vague. Moreover, sufficient ambiguity in the legislative history undermines the assertion that the antiredlining (in the sense that redlining consists of intentional geographic exclusion) underpinnings of the CRA preclude consideration of the more general problem of disinvestment. ${ }^{94}$ Both themes are evident in the legislative history. At sparsely attended Senate Banking Committee hearings on the $\mathrm{CRA},{ }^{95}$ evidence was submitted indicating that depository institutions frequently ignored their local communities' credit needs and elected to invest other than in their own communities, ${ }^{96}$ and that regulators often overlooked an

disparities in loan application processing).

${ }^{91}$ See H.R. REP. NO. 561, supra note 68, at 4 ("The purpose of [HMDA] is, by providing facts, to bring to an end more than a decade of 'red-lining' charges and counter-charges."), reprinted in 1975 U.S.C.C.A.N. at 2306.

${ }_{92}^{92}$ See, e.g., Art, supra note 62, at 1076 (stating that the redlining controversy led to the enactment of the CRA); Macey \& Miller, supra note 27, at 298 (noting that a "leading theme" in the CRA's legislative history was concern over redlining).

${ }^{93}$ See supra notes $82-87$ and accompanying text (discussing the subtle distinctions among the various definitions of "redlining" and "community disinvestment").

${ }^{*}$ See, e.g., Boehmer, supra note 62, at 621-23 (explaining that the CRA was intended to remedy disinvestment).

${ }^{95}$ The initial senate committee hearings on what was to become the CRA were held on March 23, 24, and 25, 1977. Three senators (Proxmire, Tower, and Heinz) of the 15 members of the Senate Committee on Banking, Housing, and Urban Affairs attended the first day of hearings. See Hearings on S. 406, supra note 82, at 1 . On the second day, four senators attended the hearings. See id. at 231. On the third day, attendance fell back to three. See id. at 289 .

${ }^{96}$ See, e.g., id. at 10 (statement of Sen. Proxmire) (declaring that applicants for a financial institution charter "may be interested primarily in financing their own outside business interests" or "far flung ventures" rather than "meeting the communities' credit needs"); id. at 140-46 (statement of Gale Cincotta, Chairperson, National People's Action) (presenting data revealing a similar pattern of high suburban lending and low city lending in Chicago, Philadelphia, and Hartford, Connecticut.); id. at 33761 (describing a study of Brooklyn lending patterns that revealed a common practice of investing outside of local communities). Senator Proxmire made the following comments regarding disinvestment: 
institution's performance in meeting the credit needs of its community when assessing the "convenience and needs" factor in evaluating applications filed pursuant to the Bank Holding Company Act. $^{97}$ Although a desire to eliminate redlining is replete throughout the history of the original $\mathrm{CRA},{ }^{98}$ disinvestment in general was a focus of equal concern. ${ }^{99}$

For example, in Senator Proxmire's statement introducing the bill that eventually became the CRA, redlining is not even mentioned. ${ }^{100}$ The original bill ${ }^{101}$ championed by Proxmire

[W]e find many banks and many savings and loan [sic] which take money from the community and reinvest it elsewhere, in some cases abroad, in some cases in other parts of the country. That is fine, provided it is not overdone. We have found many cases where these institutions have invested virtually nothing in the local community.

123 CONG. REC. 17,603 (1977).

${ }^{97}$ See, e.g., Hearings on S. 406, supra note 82, at 10 (statement of Sen. Proxmire) (complaining that in granting charters to financial institutions, regulators have not "extract[ed] any meaningful quid pro quo for the public"); see also 12 U.S.C. $\S 1842(c)(2)$ (Supp. V 1993) (stating the newest version of the "convenience and needs" criteria of the Bank Holding Company Act).

${ }^{98}$ See Hearings on S. 406, supra note 82, at 133 (statement of Gale Cincotta) (arguing that the CRA must prohibit discriminatory application of credit conditions and terms); id. at 150 (statement of Henry Schecter, Director, Department of Urban Affairs, AFL-CIO) (stating that the AFL-CIO's interest in combatting redlining would be furthered by the CRA); id. at 165 (statement of Carol Greenwald, Commissioner, Massachusetts State Banking Department) (proposing methods of addressing redlining); id. at 330 (statement of Sen. Garn) (pondering the difficulty of solving the redlining problem); Community Credit Needs: Hearings Before the Subcomm. on Financial Institutions Supervision, Regulation and Insurance of the House Comm. on Banking, Finance and Urban Affairs, 95th Cong., 2d Sess. 902-03 (1978) [hereinafter 1978 House Hearings] (statement of Jeffrey Zinsmeyer, Director, Neighborhood Revitalization Project of the Center for Community Change) (praising the CRA as a tool for challenging redlining); 123 CONG. REC. 17,630 (1977) (statement of Sen. Proxmire) (describing the problem of redlining); $i d$. at 17,855 (statement of Sen. Durkin) (welcoming the CRA bill for giving federal authorities a way to fight redlining); $i d$. at 17,857 (statement of Sen. Baker) (lamenting the defeat of a Senate amendment that would have eliminated the CRA title from the larger bill because of its misguided approach to solving the redlining problem).

${ }^{99}$ See Hearings on S. 406, supra note 82, at 2 (statement of Sen. Proxmire) (" $[\mathrm{T}]$ here are dozens of bankers who are either too lazy or too greedy to see the loan demand in their own communities. ... If a banker is willing to get out of the office he will find [demand]. This bill would encourage him to do so."); 123 CONG. REC. 1958 (1977) (statement of Sen. Proxmire) (introducing the bill by explaining, inter alia, that many applicants for financial institution charters have ignored the credit needs of their localities); id. at 17,603 (statement of Sen. Proxmire) (citing as a motivating concern in the CRA's enactment committee findings that financial institutions were taking money from local communities and reinvesting virtually all of it in other communities).

${ }^{100}$ See 123 CONG. REC. 1958-59 (1977).

${ }^{101}$ See S. 406, 95th Cong., 1st Sess. (1977), reprinted in Hearings on S. 406, supra 
evidenced a greater congressional intent to address disinvestment than to address redlining. Although this bill contained the same purposes as the CRA, ${ }^{102}$ the proposed legislation differed principally from the CRA with regard to its concept of "primary savings service area" (PSSA). Institutions were to delineate their PSSA, ${ }^{103}$ defined as the "compact area contiguous to a deposit facility from which such facility obtains or expects to obtain more than one-half of its deposit customers. ${ }^{\text {104 }}$ The bill proposed that an institution analyze the credit and deposit needs of its PSSA, indicate the proportion of consumer deposits obtained from depositors in its PSSA that were earmarked for reinvestment, and demonstrate that it was meeting the credit needs of its PSSA. ${ }^{105}$ The concept of PSSA would have correlated more precisely an institution's actual deposit base with its legal investment obligation by requiring disclosure of the percentage of deposits reinvested in its PSSA. Thus, as originally conceived, the CRA was intended to require a greater demonstration of "reinvestment"-that the institution was reinvesting its deposits back into its deposit base.

Swiftly, though, these reinvestment moorings began to crumble, and any original purpose became lost in controversy. Not surprisingly, the bill was met with strong objections both from members of Congress and from community activist groups. Although everybody could agree that at some level the Act's objectives were laudable-whether to preclude redlining or to promote community investment ${ }^{106}$-concerns centered first upon whether the CRA would lead to credit allocation. ${ }^{107}$ Senator Morgan's objections to

note 82 , at 3-8.

${ }^{102}$ See supra notes $33-35$ and accompanying text (noting the CRA's stated purposes).

${ }^{103}$ See S. 406, 95th Cong., 1st Sess. \$ 4(1)(A) (1977) ("Each appropriate Federal financial supervisory agency shall develop programs and procedures . . . requiring that in connection with an application for a deposit facility, the applicant delineate the primary savings service area for the deposit facility."), reprinted in Hearings on $S$. 406 , supra note 82 , at 7 .

${ }^{104}$ Id. § 3(4), reprinted in Hearings on S. 406, supra note 82, at 6.

${ }^{105}$ See id. $\S 4(1)(\mathrm{B})-(\mathrm{D})$, reprinted in Hearings on $S .406$, supra note 82, at 7.

${ }^{106}$ See, e.g., Hearings on S. 406, supra note 82, at 15 (statement of Robert E. Barnett, Chairman, FDIC) (advocating a strategy to address issues including "redlining and disinvestment"); id. at 154-55 (statement of Sen. Tower) (same); id. at 159 (statement of Sen. Heinz) (same); id. at 231 (statement of Robert Embry, Assistant Secretary for Community Development, HUD) (same).

${ }^{107}$ See, e.g., id. at 153 (statement of Sen. Tower) (stating the belief that the CRA proposal "would ... provide for a scheme of credit allocation [that could be] detrimental"); id. at 315-16 (statement of A.A. Milligan, President-Elect, American 
the CRA best embody the substance of the credit allocation concern:

In concluding, Mr. President, I would like to raise my most serious objection [to the CRA], and that is that I feel legislation of this nature is a significant step in the direction of credit allocation by the Congress of the United States.

If bills of this nature are pushed to their ultimate conclusion, then the day will come when a financial institution may be forced to make an unsound loan in a specific location in order to meet its quota of loans in a given locality. ${ }^{108}$

The most vociferous insistence that the CRA would not, and was not intended to, lead to credit allocation came from Senator Proxmire himself. Proxmire stated: "I said ... that this is not a credit allocation bill and I certainly don't see it that way. Whatever we can do to prevent it from being a credit allocation bill I want to do." ${ }^{109}$ In Proxmire's view the CRA was "mild and limited legisla-

Bankers Assoc.) (same); id. at 324 (statement of Sen. Garn) (same); SubcommitTEE ON Hous. AND COMMUNITY DEv. OF THE HOUSE COMM. ON BANKING, Fin., AND Urban AfFairs, 95TH CONG., 1ST SESS., COMPILATION OF THE Housing aNd CoMmunity Development ACt of 1977, at 356 (Comm. Print 1977) [hereinafter CRA COMPILATION] (views of Sens. Morgan, Tower, Garn, Lugar, and Schmitt) (expressing their dislike of the bill because of the alleged adverse effect of credit allocation).

For a discussion of the meaning of the term "credit allocation" and its varying forms, see Art, supra note 62, at 1083-85 (noting that the term is "ambiguous and controversial").

${ }^{108} 123$ CONG. REC. 17,628 (1977) (statement of Sen. Morgan). The following forceful and colorful statement made by Senator Garn to Senator Proxmire (during the Committee hearings on the original bill) indicates the intensity of concern over the issue:

I don't know whether I should speak at all or not. I have had a few moments to cool off. I would like you [Proxmire] to know there are some members of this committee who feel that it is the banking industry and savings and loan industry in this country who have been responsible for building this Government and not government. Damn it to hell, we have had 200 years of the private sector building the greatest country. There are problems. ... The answer isn't more rules and regulations. Piecemeal, we are heading for credit allocation and Government bureaucrats sitting back here interfering with the private sector. I'm sick and tired of the antibusiness attitude of this committee. I think the record speaks for itself. It is constant.

You come in here; you are insulted day after day, treated rudely, but the [consumer activists] have their asses kissed every day and ... told how wonderful their testimony is over and over again, while we are building up a regulatory burden that is going to destroy the housing industry in this country.

Hearings on S. 406, supra note 82, at 324 (statement of Sen. Garn).

${ }^{109}$ Hearings on $S$. 406 , supra note 82 , at 154 . For other examples of Senator 
tion"110 designed to provide a modest incentive for banks to get into their local communities more aggressively than they had in the past. ${ }^{111}$

Concerns over how this mild and limited legislation could be effectively implemented and enforced paralleled the debate over the more fundamental policy issue of credit allocation. Objections were raised that the GRA threatened to drown regulated institutions in paperwork. ${ }^{112}$ These concerns, too, were downplayed by Senator Proxmire. ${ }^{113}$ Community groups, testifying at length at the hearings on the bill, voiced different objections to the implementation of the Act. Troubled over whether the CRA provided an adequate remedy for disinvestment and redlining, activists suggested enhancing the enforcement teeth of the bill. ${ }^{114}$

Nonetheless, these objections fell on deaf ears. Other than with respect to the concept of PSSA, for which the Senate substituted the notion of "community,"

Proxmire's assurances that the CRA would not lead to credit allocation, see $i d$. at 2 (stating that the CRA is not a credit allocation statute); id. at 11 (stating that the CRA is not intended to force high-risk loans); $i d$. at 293 (stating that the bill is not designed to impede the flow of capital). Proxmire's steadfast insistence that the CRA was not intended as a credit allocation statute continued long after enactment. See Provisions Aimed at Strengthening the Community Reinvestment Act: Hearings Before the Senate Comm. on Banking, Housing, and Urban Affairs, 100th Cong., 2d Sess. 1 (1988) (statement of Sen. Proxmire) ("From the beginning ... I have been leery of credit allocation schemes run by the Federal Government.").

${ }^{110}$ Hearings on S. 406, supra note 82, at 399; see also id. at 293 (statement of Sen. Proxmire) ("There is no question that the bill is limited and limited in its effect."); $i d$. at 323 (statement of Sen. Proxmire) (stating that the CRA is a "mild" proposal); $i d$. at 328 (statement of Sen. Proxmire) (stating that the CRA is "mild").

${ }^{111}$ See id. at 326 (statement of Sen. Proxmire) ("I am trying to propose legislation that would provide some mild incentive to persuade the banks to get into their local communities more aggressively than they have in the past ....").

${ }^{112}$ See id. at 363 (statement of Morris D. Crawford, Jr., Chairman, Bowery Savings Bank) (expressing fear of paperwork burdens); 123 CONG. REC. 17,628 (1977) (statement of Sen. Morgan) (urging other senators to vote to "delete this burdensome and counterproductive piece of legislation"); id. at 17,636 (statement of Sen. Schmitt) ("[T]his legislation would require a great deal of additional paperwork . . .."); CRA COMPILATION, supra note 107, at 358 (views of Sens. Morgan, Tower, Garn, Lugar, and Schmitt) (expressing similar concerns).

${ }^{113}$ See Hearings on S. 406, supra note 82, at 293 ("We do not have any notion that we would impose a big paperwork burden here."); 123 CoNG. REC. 17,604 (1977) (arguing that there was no indication of an unusual paperwork burden).

it4 See Hearings on S. 406, supra note 82, at 20 (statement of Ralph Nader) (urging the allowance of standing for judicial review of agency CRA actions); id. at 222 (statement of Conrad Weiler, Chairman, Alliance for Neighborhood Government) (urging the allowance for public hearings and citizen review); id. at 229 (statement of Conrad Weiler) (discussing remedial mechanisms).

${ }^{115}$ See CRA COMPILATION, supra note 107, at 92 ("The Senate provisions . . would 
seven-to-seven vote) the review of the Senate Banking Committee. ${ }^{116}$ The Act subsequently was passed, in spite of evidence that even the regulators who would be responsible for enforcing the CRA opposed its enactment ${ }^{117}$ and in spite of spirited debate on a proposed Senate amendment to delete the CRA from the housing bill being considered. ${ }^{118}$ Regulators were now presented with the unenviable task of devising a means of enforcing the Act. This task was complicated by the problem of taking care to avoid credit allocation and to minimize paperwork, and the problem of furthering a legislative purpose that-although undeniably rhetorically appealing-shifted like a chameleon between disinvestment and redlining.

\section{B. Regulatory Response}

The brevity of the actual Act and the meager attempt by Congress to articulate a purpose for the Act has rendered the bulk of the substantive import of the law a regulatory matter. Each federal supervisory agency has issued its own set of regulations pursuant to the Act, but all are substantially identical. ${ }^{119}$ This section will first discuss regulators' initial efforts-based approach toward enforcement and the problems and concerns that arose under that approach and that ultimately led to demands for overhaul of the existing enforcement regime. ${ }^{120}$ The section then discusses the new enforcement regulations that have emerged from the controversy. ${ }^{121}$ Central to these regulations is a shift from measuring an institution's CRA compliance by its efforts to

substitute consideration of the credit needs of the 'entire community' ... for the credit needs of its 'primary service area."); see also supra text accompanying notes $102-05$.

${ }^{116}$ See 123 CONG. REC. 17,625 (1977).

117 See id. at 17,628-29 (statement of Garth Marston of the Fed. Home Loan Bank Board) (" $[\mathrm{T}]$ he bill's possible goals are many and ill-defined and it constructs an enforcement mechanism which is unfair [and] may well be unworkable . ...").

${ }^{118}$ See id. at 17,625 (statement of Sen. Morgan) (urging passage of an amendment to delete the CRA-Title IV of the act). The amendment was defeated by a vote of 40 to 31 . See id. at 17,637 .

119 The pre-1995 CRA regulations of the federal supervisory agencies are found at 12 C.F.R. $\$ 25$ (1993) (Office of the Comptroller of the Currency regulations), 12 C.F.R. $\$ 228$ (1993) (Federal Reserve Board regulations), 12 C.F.R. $\$ 345$ (1993) (FDIC regulations), and 12 C.F.R. $\$ 563$ e (Office of Thrift Supervision regulations). Because the regulations are substantially identical, for ease of citation, reference will be made only to the Federal Reserve Board's regulations.

${ }^{120}$ See infra part I.B.1.

121 See infra part I.B.2. 
measuring compliance by its actual performance in meeting the credit needs of the area which it serves. ${ }^{122}$ Finally, the section suggests that, although facially the new enforcement regulations appear to be a substantial shift toward ameliorating the problems that have been identified with the CRA, depending upon regulators' attitudes toward enforcement there arguably may be little difference between the two approaches to CRA enforcement, except perhaps the potentially greater expense to financial institutions. ${ }^{123}$

\section{Original Enforcement Regulations}

The original CRA enforcement regulations implemented in 1978 imposed three basic substantive requirements on regulated institutions: community delineation, disclosure, and compliance. The responsibility for defining the institution's community ("community delineation") was left to the institution itself. ${ }^{124}$ The community delineation could not exclude low- or moderate-income $\operatorname{areas}^{125}$ and had to include the contiguous area surrounding the offices of the lender. ${ }^{126}$

${ }^{122}$ See infra part I.B.2.a-b.

${ }^{123}$ See infra part I.B.3.

${ }^{124}$ See 12 C.F.R. $\$ 228.3$ (1993). Institutions that primarily served a military clientele could determine their community without reference to geography. See $\S 228.3(\mathrm{c})$.

${ }^{125}$ See $\$ 228.3(\mathrm{a})$.

${ }^{126}$ See $\$ 228.3(b)$. In determining the area that constituted its community, the institution could use (1) the Standard Metropolitan Statistical Areas or political boundaries or portions thereof surrounding the offices or branches of the institution, (2) the local lending area or areas surrounding each office or groups of offices in which the bank made a substantial portion of its loans, and all other areas equidistant from those areas, and (3) any other reasonably delineated local area that met the purpose of the CRA. See $\$ 228(b)(1)-(3)$. Adjustments could be made to take into account state boundaries, significant geographical features, and extremely large or unusual community configurations. See $\$ 228.3(b)(1)$. The community delineation was reviewed annually by the institution, see $\$ 228.3(\mathrm{a})$, and was reviewed during the institution's CRA examination. See $\$ 228.5(\mathrm{a})-(\mathrm{d})$.

A recent Department of Justice ECOA investigation of alleged discriminatory practices by Decatur Federal Savings and Loan Association indicated a move toward a closer review of an institution's defined "community" than perhaps existed before. See supra note 78 (discussing the investigation, generally). In that case, evidence that Decatur had since 1979 circumscribed its CRA lending area to exclude most black neighborhoods in Atlanta and Fulton County, Georgia provided support for charging Decatur with violations of the ECOA and the Fair Housing Act. See 1 SENATE PRINT, supra note 5, at 5-6 (quoting excerpts from the Decalur Federal complaint). Similarly, in one of the few Federal Reserve Board denials of applications on CRA grounds, the Board relied in part on the fact that the institution had unreasonably excluded a nearby Native American reservation from its community. See First Interstate 
The disclosure mechanism had both a notification element and an informative element. First, an institution was required to post a CRA Notice in its lobbies. ${ }^{127}$ This Notice informed the public about public access to information concerning the institution's CRA performance, ${ }^{128}$ about the right to submit comments on the institution's CRA performance to the institution's regulatory agency, and about the right to request announcement of applications covered by the CRA with the regulatory agency. ${ }^{129}$

The principal disclosure provisions were more substantive. As stated above, the CRA was amended in 1989 to require more extensive disclosure. ${ }^{130}$ The institution was required to prepare, annually review, and make available to the public a CRA Statement. ${ }^{131}$ The CRA Statement was to include the institution's community delineation, a list of the specific types of credit that the bank had committed to extend to the community, and a copy of the institution's CRA Notice, discussed above. ${ }^{132}$ In addition, institutions were encouraged to include in their CRA Statement descriptions of efforts to ascertain and to meet its community's needs, and a report on its record of actually meeting those community needs. ${ }^{133}$

Since 1989, the extent of an institution's compliance with the CRA was measured through the four-tier rating system now contained in the statute itself. ${ }^{134}$ To arrive at an institution's CRA rating, the examining agency would review the institution's CRA Statement and accompanying written comments, and would

BancSystem of Montana, Inc., 77 Fed. Res. Bull. 1007, 1007-08 (1991) (noting the unreasonableness of excluding the Native American population from the institution's community).

${ }^{127}$ See 12 C.F.R. $\$ 228.6$ (1993).

${ }^{128}$ See id. The CRA Notice included information on the public's access to the institution's current and past CRA Statements and written comments received by the regulatory agency. See id.

${ }^{129}$ See id.

${ }^{130}$ See supra notes 38-39 and accompanying text (discussing the written evaluation portion of CRA enforcement).

${ }^{131}$ See 12 C.F.R. § 228.4(a) (1993).

${ }^{132}$ See $\S 228.4($ a). Files were to be maintained for public inspection. See $\$ 228.5$. The files were to contain signed, written comments received by the public within the previous two years that relate to the institution's CRA Statement or its CRA performance, responses to these comments, CRA Statements from the previous two years, and a copy of the public portion of the institution's most recent CRA performance evaluation. See $\S 228.5$.

${ }^{133} \mathrm{See} \S 228.4(\mathrm{c})$.

${ }^{134}$ See supra note 38 and accompanying text (detailing the four possible ratings and their statutory history). 
consider a list of factors, all principally devoted to the efforts of the institution to meet community credit needs. ${ }^{135}$ The evolution of these factors represents the manner in which regulatory attitudes toward CRA compliance have changed since 1977. The 1980 public information statement of the Federal Financial Institutions Examination Council (FFIEC) paid scant attention to the precise means by which a regulated institution could comply with the Act. ${ }^{136}$ In contrast, the 1989 Agency Joint Policy Statement on the

${ }^{135}$ The assessment factors with respect to state member banks were as follows:

(a) Activities conducted by the State member bank to ascertain the credit needs of its community, including the extent of the bank's efforts to communicate with members of its community regarding the credit services being provided by the bank;

(b) The extent of the State member bank's marketing and special credit-related programs to make members of the community aware of the credit services offered by the bank;

(c) The extent of participation by the State member bank's board of directors in formulating the bank's policies and reviewing its performance with respect to the purposes of the Community Reinvestment Act;

(d) Any practices intended to discourage applications for types of credit set forth in the State member bank's CRA Statement(s);

(e) The geographic distribution of the State member bank's credit extensions, credit applications, and credit denials;

(f) Evidence of prohibited discriminatory or other illegal credit practices;

(g) The State member bank's record of opening and closing offices and providing services at offices;

(h) The State member bank's participation, including investments, in local community development and redevelopment projects or programs;

(i) The State member bank's origination of residential mortgage loans, housing rehabilitation loans, home improvement loans, and small business or small farm loans within its community, or the purchase of such loans originated in its community;

(j) The State member bank's participation in governmentallyinsured, guaranteed, or subsidized loan programs for housing, small businesses or small farms;

(k) The State member bank's ability to meet various community credit needs based on its financial condition and size, and legal impediments, local economic conditions and other factors; and

( $l$ ) Other factors that, in the Board's judgment, reasonably bear upon the extent to which a State member bank is helping to meet the credit needs of its entire community.

12 C.F.R. $\$ 228.7$ (1994).

${ }^{136}$ See 45 Fed. Reg. 63,133-34 (1980) (mentioning the institutions' affirmative obligations under the CRA). The 1980 Information Statement did little more than briefly describe the Act's requirements and indicate that the agencies expected institutions to comply with the Act. Activities that would constitute compliance were articulated as vague directives. For example, the statement mentions that, in assessing compliance, " $[\mathrm{t}]$ he regulatory agencies are concerned with the lender's performance 
$\mathrm{CRA}^{137}$ and the 1990 FFIEC revised rating system and final guidelines ${ }^{138}$ adopted a much more comprehensive approach to the issue of CRA compliance and grading procedures. In the 1990 guidelines, the regulatory factors ${ }^{139}$ were divided into five general categories in which the institution was evaluated to determine its overall CRA rating: (1) Ascertainment of Community Credit Needs, ${ }^{140}$ (2) Marketing and Types of Credit Offered and Extended, ${ }^{141}$ (3) Geographic Distribution and Record of Opening and Closing Offices, ${ }^{142}$ (4) Discrimination and Other Illegal Credit Practices, ${ }^{143}$ and (5) Community Development. ${ }^{144}$ Detailed discussions of the efforts required for the institution to obtain an outstanding, satisfactory, needs to improve, or substantial noncompliance grade in each of the performance categories were included. ${ }^{145}$

Despite the growing trend toward specificity and what facially appeared to be a neutral grading system, financial institutions,

in meeting the credit needs of its local communities and with its sensitivity and response to the needs of each neighborhood." Id. at 63,134 .

${ }^{137}$ See 54 Fed. Reg. 13,742 (1989). The 1989 Policy Statement discussed in detail the agencies' guidelines for developing an effective CRA process and the specific elements of that process. See id. at 13,743-44. The statement also addressed the agencies' views on the CRA statement, documentation, the examination process, and the role of the CRA evaluation in the examination process. See id. at 13,745-46.

${ }^{138}$ See 55 Fed. Reg. 18,163 (1990).

${ }^{139}$ See supra note 135 (listing the regulatory factors).

${ }^{140}$ This category addressed the institution's "employment of effective techniques for gathering information to identify community credit needs" and subsumed regulatory assessment factors (a) (activities to ascertain credit needs) and (c) (participation by board of directors). 55 Fed. Reg. at 18,169.

141 This category addressed the institution's efforts to promote the credit it offers, its product implementation, and overall delivery of credit services relative to its CRA Statement. See id. at 18,171 . The category subsumed regulatory assessment factors (b) (marketing efforts), (i) (housing, small business, and farm loan origination), and (j) (participation in government loan programs). See id.

${ }^{142}$ This category addressed the reasonableness of the institution's community delineation, geographic loan distribution, and the effects of opening and closing of offices. See id. at 18,173. This category subsumed regulatory assessment factors (e) (geographic distribution) and (g) (record of opening and closing offices). See id.

${ }^{145}$ This category addressed compliance with antidiscrimination laws and subsumed regulatory assessment factors (d) (practices that discourage applications) and ( $f$ ) (evidence of discriminatory activities). See id. at 18,174.

It This category addressed the institution's "participation in community development and/or other factors relating to meeting local credit needs." Id. at 18,174. The category subsumed regulatory assessment factors (h) (participation in community development and redevelopment projects), (k) (ability to meet credit needs), and (l) (other factors). See id. at 18,174-75.

${ }^{145}$ See id. at $18,169-75$. 
regulators, and community groups were highly critical of the lack of differentiation generated under the four-tier rating system mandated by the Act. ${ }^{146}$ Under that system, a substantial majority of institutions-predominantly smaller, independent banks-were just "Satisfactory." 147 The lack of differentiation among institutions became more problematic when viewed in conjunction with the heightened disclosure requirements of the CRA. Not only was nearly every institution merely "Satisfactory," but that fact was disclosed to a public ignorant of the intricacies and vagaries of the CRA grading procedures. Congress, which itself had changed the grading system from a more discriminating five-tier scale to the less discriminating four-tier scale, blamed lax grading by regulators as the cause of the lack of differentiation in CRA ratings. ${ }^{148}$ In

${ }^{146}$ See A 'Better than Satisfactory' Grade?, AM. BANKER, June 15, 1992, at 10 (complaining that the percentage of institutions receiving a grade of "satisfactory," about $80 \%$, is much too large).

147 In 1993 and 1994, respectively, $93 \%$ and $94 \%$ of institutions examined received a "Satisfactory" grade or better. See Claudia Cummins, 93\% of CRA Exams Last Year Brought Award of 2 Top Grades, AM. BANKER, Jan. 10, 1994, at 3; Shannon Henry, Record 94\% of Ratings 'Outstanding' or 'Satisfactory', AM. BANKER, Jan. 26, 1995, at 10. This reflected a slight inflation in grades from 1992. For institutions rated from January 1 to September 30, 1992, 13\% overall received an "Outstanding," 77\% received a "Satisfactory," 9\% received a "Needs to Improve," and 1\% received a "Substantial Noncompliance." See Griffith L. Garwood \& Delores S. Smith, The Community Reinvestment Act: Evolution and Current Issues, 79 Fed. Res. Bull. 251, 258 tbl. 1 (1993). Smaller institutions (with assets of less than $\$ 100$ million) received more of the lower grades: $10 \%$ received "Outstanding," $80 \%$ received "Satisfactory," 9\% received "Needs to Improve," and $1 \%$ received "Substantial Noncompliance." See id. In contrast, larger institutions (with assets of over $\$ 10$ billion) cornered the market on higher grades: $42 \%$ received "Outstanding," $58 \%$ received "Satisfactory," $0 \%$ received "Need to Improve," and $0 \%$ received "Substantial Noncompliance." See id.

Under the prior five-tier numerical scale, the ratings appeared to be more differentiable. For example, in 1980 the ratings for State member banks examined by the Federal Reserve were as follows: 1 (= outstanding): $3.5 \% ; 2$ (= good): $36.7 \%$; 3 (= satisfactory): $56.7 \% ; 4$ (= needs improvement): $2.9 \%$; and 5 (= unsatisfactory): 0.2\%. See Glenn Canner, The Community Reinvestment Act: A Second Progress Report, 67 Fed. Res. Bull. 813, 816 tbl. (1981).

${ }^{148}$ In 1988, Senator Proxmire chastised the agencies for their lax grading:

Regulators seem to think that we're all living in Lake Woebegone. Like the children of the fictional village, U.S. lenders are all above average. Almost all get high ratings year after year and almost none is ever held back.

The committee surveyed CRA rating procedures and found that more than 97 percent of all lenders passed with flying colors. ... I wish we had graders like that when $I$ was in school.

And I ask myself, how is it that so many neighborhoods are continuing to fail while so many lending institutions are continuing to pass? This 
addition, Congress excoriated the lack of qualitative consistency, both among and within the evaluating agencies, in the content and detail of their written evaluations of institutions that received the same overall $C R A$ rating and those that received different ratings. ${ }^{149}$

In addition to the claimed deficiencies in the CRA rating process, regulators' implementation of the Act's modest enforcement provisions generated controversy. For institutions that remained unaffected by negative publicity and that had no desire to expand, public disclosure of CRA ratings provided little incentive to attempt to get a better rating. ${ }^{150}$ Although regulators had gone to the extreme of issuing cease-and-desist orders against institutions on CRA grounds, they did so only on two occasions. ${ }^{151}$ Accordingly, other than with respect to blatant noncompliance, the primary carrot-or stick-that ensured CRA performance was consideration of the performance in evaluating applications to the agencies for expanded privileges. ${ }^{152}$ The scrutiny to which an institution's CRA record would be subject in the application process was an evolving matter. Prior to $1989, \mathrm{CRA}$ compliance in the evaluation of merger applications was not an insurmountable hurdle. Few applications were protested by community groups ${ }^{153}$ and those

record, needless to say, raises questions about whether the examination process has succeeded. This record fails the nudge test which for me is an essential measure of progress under CRA.

1988 Senate Hearings, supra note 5, at 7-8 (statement of Sen. Proxmire). Sharp criticism in the same vein continued through 1992. See 1 SENATE PRINT, supra note 5 , at 6 (criticizing regulators' "poor enforcement record").

${ }^{149}$ See 2 SENATE PRINT, supra note 5, app. A at 86-144 (providing examples of inconsistent written evaluations within groups of institutions given the same CRA rating). For example, the evaluations varied widely as to the specificity of the evaluation and as to regulators' guidance on exactly how an institution could improve its performance. While some institutions received a detailed analysis of the reasons for their rating under a particular category, others did not, and were given little guidance as to how to improve the rating given. See id.

${ }^{150}$ See, e.g., Bill Atkinson, A Bank that Won't Bend to Meet CRA Standards, AM. BANKER, Apr. 22, 1991, at 6 (noting that a bank that received a "substantial noncompliance" rating "isn't budging to change the rating").

${ }^{151}$ See Kenneth H. Thomas, Is CRA Enforcement Consistent?, AM. BANKER, May 1, 1992 , at 4 (noting that the 1992 Farmers and Merchants Bank cease-and-desist order was the second such order issued).

${ }^{152}$ See supra text accompanying note 40 (listing a number of privileges, the granting of which may be affected by an institution's low CRA performance).

${ }^{153}$ See 1988 Senate Hearings, supra note 5, at 216 (statement of Martha R. Seger, member, Board of Governors of the Fed. Reserve Sys.) (noting protested applications from 1978-1987); see also Canner, supra note 147, at 816 (noting that few applications by low-rated institutions were ever protested). 
that were protested were easily resolved through negotiations and a promise of future commitments by the institution to improve its CRA performance. ${ }^{154}$ While CRA protests were not unheard of, ${ }^{155}$ and while those protests could lead to substantial delays in approval of the protested application, ${ }^{136}$ approval seemed assured, regardless of the institution's CRA rating.

Two events in 1989 acted to check growing perceptions of a lazy regulatory attitude toward CRA compliance. First, the 1989 Agency Joint Policy Statement ${ }^{157}$ indicated a more invigorated attitude of regulators toward CRA evaluations. ${ }^{158}$ In addition, the Federal Reserve Board rejected the application of Continental Bank Corporation and Continental Illinois Bancorp to acquire an Arizona bank. ${ }^{159}$ While the denial was partially on the grounds that Continental was still controlled by the Federal Deposit Insurance Corporation, ${ }^{160}$ Continental's CRA-deficient performance was also a determining factor. ${ }^{161}$ Continental had recently elected to change its long-term business strategy by becoming a wholesale banking institution and had therefore withdrawn from consumer

${ }^{154}$ See, e.g., Canner, supra note 147, at 816-17 (suggesting that most protested applications are eventually approved upon the taking of remedial action or the promise of future commitments); Glenn Canner \& Joe M. Cleaver, The Community Reinvestment Act: A Progress Report, 66 Fed. Res. Bull. 87, 91-95 (1980) (discussing the resolution of protested applications).

155 Protests to applications showed dramatic increases in 1985 and in 1987. See 1988 Senate Hearings, supra note 5, at 216 (noting that between 1984 and 1985, protested applications rose from 3 to 19 , and that they rose from 20 to 36 between 1986 and 1987).

${ }^{156}$ See id. at 13 (statement of ACORN) (discussing the eight-month delay in the application of Hibernia National Bank to acquire a bank, "the longest delay in the history of CRA challenges").

${ }^{157}$ See supra note 137 and accompanying text.

${ }^{158}$ See Garwood \& Smith, supra note 147, at 254 (discussing the 1989 policy statement, which "added specificity about the responsibilities of institutions under the CRA, the manner in which the agencies would assess performance, and some of the elements found in effective programs").

${ }^{159}$ See Continental Bank Corp., Order Denying Acquisition of a Bank, 75 Fed. Res. Bull. 304 (1989) (denying the corporation's application for approval to buy the Grand Canyon State Bank).

${ }^{160}$ See id. at 306 (stating that denial of the application was partially based on "the adverse effects on competition resulting from the continued government ownership of [the] Bank").

${ }^{161}$ See id. (noting that the decision to deny the application was in part "based upon [the] Bank's inadequate CRA performance"). Among other things, Continental had only recently implemented a formal CRA program, had CRA Statements that were "substantially inaccurate," and had made little effort to market its products or participate in community development projects. Id. at 305. 
credit and retail banking services. ${ }^{162}$ The Board commented that the CRA nonetheless required Continental to implement an active CRA program consistent with that business objective, ${ }^{163}$ and refused to consider any commitments of Continental to improve its GRA performance in the future. ${ }^{164}$

Post-Continental, the CRA was transformed into a requirement that an institution had to take seriously or face the real possibility of denial of its application. ${ }^{165}$ An institution's CRA record therefore emerged as a principal point of contention in evaluating its application for expansion. Although only between one and two percent of applications filed with the Federal Reserve have been protested on CRA grounds since $1988,{ }^{166}$ and denials of application on CRA grounds were-and still are-rare, ${ }^{167}$ the CRA became

${ }^{162}$ See Robert Reed, Why Theobald Strategy for Cont'l Faces Hurdles, CRaIN's Chicago BUS., Nov. 2, 1987, at 2, 2 (announcing Continental's strategic plan).

${ }^{163}$ See Continental Bank Corp., supra note 159, at 304-05 (stating that "[a]lthough the CRA was not intended to limit an institution's discretion to develop the types of products and services it believes are best suited to its expertise and business objectives, ... the institution's program must meet the objectives of the CRA ${ }^{7}$ ). Continental could, in the Board's view, comply with the CRA without contravening its business structure by

lending to inner-city revitalization efforts, supporting state and local governmental financing efforts, lending to small or minority-owned businesses, lending support for low-income multi-family rehabilitation and new construction projects, lending to or otherwise financing non-profit developers of low-income housing and small business development, or financing major upgrades and/or expansion of industrial plants that would otherwise relocate outside of the city served by the bank.

Id.

${ }^{164}$ See id. at 305 ("The Board does not believe that commitments by themselves can serve as a substitute for the established record of CRA performance required by the statute.").

${ }^{165}$ Some commentators erroneously have suggested that it was the 1989 FIRREA amendments to CRA that finally put teeth into enforcement. See Macey \& Miller, supra note 27, at 292-93 (discussing the enhanced impact of the CRA as a result of the 1989 changes); see also supra notes 38-39 and accompanying text (discussing the 1989 amendments). Although the hearings that preceded FIRREA and their sharp criticisms of regulatory enforcement efforts to date might have incited regulators to crack down on CRA compliance, the text of the 1989 amendments-heightened disclosure and the four-tier grading system-does not by itself dramatically invigorate the CRA. In addition, as stated carlier, consumer group protests of applications had already begun to rise prior to 1989 . See supra note 155 .

${ }^{166}$ See Garwood \& Simith, supra note 147 , at 259 . The limited number of protests might be a misleading indicator of the efficacy of CRA enforcement. Even in the absence of a formal protest, CRA compliance might become an issue in the application process because of deficiencies in the applications revealed during the CRA examination process. See id.

167 See 1 SENATE PRINT, supra note 5, at 184 (setting forth Federal Reserve Board 
an issue of almost overwhelming proportions in larger transactions. For example, in BankAmerica Corporation's application to acquire Security Pacific, the Federal Reserve Board conducted public hearings in four cities and heard the testimony of approximately 175 witnesses, ${ }^{168}$ even though Bank of America, BankAmerica's lead bank, had received "outstanding" CRA ratings in 1990 and Security Pacific's subsidiary national banks consistently had received "satisfactory" CRA ratings. ${ }^{169}$ Although the merger ultimately was approved, ${ }^{170}$ community groups, during the hearing process, were able to extract from BankAmerica commitments amounting to $\$ 12$ billion in community-based lending after the merger. ${ }^{171}$ NCNB's acquisition of C\&S/Sovran ${ }^{172}$ and Chemical Bank's merger with Manufacturers Hanover ${ }^{173}$ generated similar CRA scrutiny ${ }^{174}$ and

application dispositions). Only one of 27 CRA-protested applications accepted in 1990 by the Federal Reserve Board was denied. See id. That denial involved the application of First Interstate BancSystem to merge with Commerce BancShares of Wyoming. See First Interstate BancSystem of Montana, Inc., 77 Fed. Res. Bull. 1007, 1007 (1991). The Board found that First Interstate's banking subsidiary serving the Northern Cheyenne Indian Reservation had "made no effort to ascertain the credit and banking needs of this community," "failed to offer and market credit-related services to this community," and "unreasonably delineated its service area to exclude this community." Id. In three out of five CRA performance categories, the bank had received a "needs to improve" rating. Id. at 1008 n.7.

All in all, denials on CRA grounds have been infrequent. Until 1993, the Federal Reserve Board had denied applications to merge only four times on CRA grounds. See Robert B. Cox, First Colonial's Plan to Buy Banks Rejected by Fed on CRA Grounds, AM. BANKER, May 20,1993, at 6. Yet, some indicators have evidenced a harder line being taken by regulators in the last few years. In early 1994, the Office of Thrift Supervision denied on CRA grounds the applications of four thrifts for charter changes. See Robyn Meredith, OTS Cites Poor CRA Grades in Blocking Four Charter Flips, AM. BANKER, Feb. 22, 1994, at 4. Each of the thrifts, who sought to become state-chartered savings banks, had received a "needs to improve" CRA rating. See id.

${ }^{168}$ See Garwood \& Smith, supra note 147, at 259-60.

${ }^{169}$ See BankAmerica Corp., 78 Fed. Res. Bull. 338, 347 \& nn.48-49 (1992).

${ }^{170}$ See id. at 359.

${ }^{171}$ See id. at 356-57. Specifically, BankAmerica committed $\$ 750$ million for lowerincome and minority home mortgage loans, $\$ 150$ million for low-income rental housing construction, $\$ 200$ million for conventional small business loans, $\$ 100$ million for government-backed small business loans, and $\$ 12$ million for lower-income consumer credit. See id. at 356.

${ }^{172}$ See Statement by the Board of Governors of the Fed. Reserve Sys. Regarding the Application by NCNB Corp. to Acquire C\&S/Sovran Corp., 78 Fed. Res. Bull. 141 (1992) [hereinafter NCNB].

${ }^{173}$ See Chemical Banking Corp., 78 Fed. Res. Bull. 74-75 (1992) [hereinafter Chemical].

${ }^{174}$ See NCNB, supra note 172, at 147-57 (summarizing the public meetings and written comments regarding NCNB's acquisition application); Chemical, supra note 173 , at 78-82 (discussing Chemical's performance record as analyzed by the Board in 
resulted in expansive commitments from the institutions. ${ }^{175}$

The increased scrutiny of CRA performance in the application process generated an avalanche of complaints from the financial community. First, the added emphasis on the CRA, and the real (albeit remote) possibility of denial of an application, arguably prevented some institutions with a low rating from pursuing an application. ${ }^{176}$ Those that did file applications (irrespective of their CRA rating) now could expect lengthy delays, exhaustive public hearings, and pressure from community groups for future commitments to ensure that the deal went through. Financial institutions also alleged that, contrary to the intent expressed in the debate, the agencies required extensive paperwork at the expense of actual CRA results. ${ }^{177}$ Congress, too, levied criticisms at regulators for exalting process-and paperwork-over results. ${ }^{178}$

assessing its application). In the evaluation of NCNB, the Board held three days of hearings in four cities. See NCNB, supra note 172, at 147.

175 See NCNB, supra note 172, at 157 (describing NationsBank's $\$ 10$ billion lending program); Chemical, supra note 173, at 81-82 (discussing the banks' commitment to provide $\$ 750$ million in additional lending for low- and moderate-income communities).

${ }^{176}$ See, e.g., Ed Dillon, Scuttled Deal in the West Illustrates Impact of CRA, АM. BANKER, Jan. 8, 1992, at 9 (discussing Harris Bankcorp's election not to pursue application for acquisition after receiving a "needs to improve" rating).

177 See, e.g., Bill Atkinson, Despite Good Grades, Banks Say CRA Exams Were Not a Pushover, AM. BANKER, Apr. 22, 1991, at 1 (noting that regulators look for extensive documentation and form); Linda Corman, Study Finds Documentation Biggest Factor in CRA Rating, AM. BANKER, June 3, 1991, at 7 (expressing one bank's opinion that large banks receive better ratings as a result of their capacity to document CRA performance elaborately); Foreman \& Brunson, supra note 3, at 35 (acknowledging the opinion that the excessive emphasis on documentation may result in the industry missing its mark).

Despite these complaints, the old CRA could be viewed as a relatively inexpensive regulation with which to comply. An Office of Management and Budget review of estimates of the time and cost of compliance for the CRA under the old regime found that state member banks regulated by the Federal Reserve spent 6137 hours and $\$ 306,850$ on CRA compliance. See Bill Atkinson, Complying with Regulations: A Costly and Growing Burden, AM. BANKER, June 24, 1991, at 1, 10. In contrast, compliance with Truth-in-Lending required 1.9 million hours and $\$ 7.3$ million. See id.; see also infra note 379 (suggesting that claims of compliance costs and burdens are exaggerated).

${ }_{178}$ See 1 SENATE PRINT, supra note 5, at 11-13 (recommending that regulators shift emphasis from paperwork to actual performance). 


\section{The Turn Toward Results}

Acting against the backdrop of these complaints, in December of 1993 the regulatory agencies published for comment their initial proposed revisions to the CRA regulations. ${ }^{179}$ After regulators were inundated with comments on that proposal, ${ }^{180}$ a substantially revised set of proposals emerged in October of 1994, and final rules were approved by regulators in late April of $1995 .^{181}$ Although the public disclosure requirements remain largely the same, ${ }^{182}$ the new regulations abandon the efforts/process-based enforcement standard that had been in effect since 1978. The regulations advance an evaluative procedure that is based, at least initially, upon actual results, including loans, investments, and services to an institution's "assessment area."

\section{a. Compliance and Enforcement}

Most significant in the new regulations are the abandonment of the prior subjective, efforts-based criteria for assessing whether an institution is meeting community credit needs and the substitution of what at least facially seems a more quantitative evaluation procedure designed to measure actual results in meeting the credit needs of the institution's service area. Under the performance standards for large, retail institutions, three tests are conducted to generate raw ratings that are then used to compute an institution's composite CRA rating. ${ }^{184}$

179 See December 1993 Proposed Regulations, supra note 11. For a general discussion of the 1993 revised regulations, see supra notes $9-15$ and accompanying text.

${ }^{180}$ See supra note 15 and accompanying text.

${ }^{181}$ See Community Reinvestment Act Regulations, 60 Fed. Reg. 22,156 (1995) (to be codified in scattered sections of 12 C.F.R.) (joint final rules) [hereinafter Final Regulations]; Community Reinvestment Act Regulations, 59 Fed. Reg. 51,232 (1994) (proposed Oct. 7, 1994) [hereinafter 1994 Proposed Regulations]. For a general discussion of the 1994 proposed revisions, see supra note 16 and accompanying text. Again, each of the four regulatory agencies involved issued substantially the same regulations. Further citations will make reference to C.F.R. sections of the final Federal Reserve Board regulations. See Final Regulations, supra (to be codified at 12 C.F.R. §§ 228.11-.51).

${ }^{182}$ Covered institutions must maintain files for public inspection including information on its CRA performance, see Final Regulations, supra note 181 (to be codified at 12 C.F.R. $\$ 228.43(\mathrm{a})$-(b)), and public notice that CRA information is available. See id. (to be codified at 12 C.F.R. $\$ 228.44$ and 12 C.F.R. pt. 228, app. B).

${ }^{183}$ The concept of "assessment area" replaces the old "community" requirement. See id. (to be codified at 12 C.F.R. $\S 228.41$ ).

${ }^{184}$ Although each individual test for large retail institutions now has a five-tiered 
Under the "Lending Test," the institution's performance in meeting community credit needs is evaluated by measuring the institution's home mortgage lending, small business and small farm lending, community development lending, ${ }^{185}$ and, if consumer lending constitutes a substantial majority of the institution's business, consumer lending. ${ }^{186}$ The rating under the Lending Test hinges on the institution's responsiveness to the credit needs of its assessment area, ${ }^{187}$ the degree of lending in its assessment area, ${ }^{188}$ the geographic distribution of loans throughout its assessment area and among individuals of different income levels and businesses, ${ }^{189}$ its record in meeting the credit needs of highly

rating system-a response to complaints over the lack of differentiation in ratings-the overall rating is one of the four required by the statute. See id. (to be codified at 12 C.F.R. $\$ 228.28(\mathrm{a})$ and 12 C.F.R. pt. 228, app. A); see also supra note 38 and accompanying text (discussing the four-tier rating system).

${ }_{185}$ "Community development loans," generally, are loans that have as their primary purpose "community development." Final Regulations, supra note 181 (to be codified at 12 C.F.R. $\S 228.12(i)$ ). "Community development" focuses on activities in low- and moderate-income geographies and includes affordable housing (including multifamily rental housing), community services, and revitalization efforts. Id. (to be codified at 12 C.F.R. $\$ 228.12(\mathrm{~h})$ ). Such loans must benefit the institution's assessment area or a broader regional or statewide area that includes the assessment area. See id. (to be codified at 12 C.F.R. $\$ 228.12(\mathrm{i})(2)(\mathrm{ii})$ ).

${ }^{186} \mathrm{See} i d$. (to be codified at 12 C.F.R. $\$ 228.22(a)(1)$ ). When assessing the institution's overall lending performance in home mortgage lending, small business lending, and small farm lending, the evaluator must consider the institution's lending activity, see id. (to be codified at 12 C.F.R. $\$ 228.22(\mathrm{~b})(1)$ ), the geographic distribution of the institution's lending patterns, see id. (to be codified at 12 C.F.R. $\S 228.22(b)(2)$ ), the characteristics of the individual borrowers, see id. (to be codified at 12 C.F.R. $\$ 228.22(b)(3)$ ), which encompasses an assessment of the distribution of lending to individuals by income group and to small farms and small businesses, see id. (to be codified at 12 C.F.R. $\$ 228.22$ (b)(3)(i)-(iv)), and the institution's use of innovative or flexible lending practices. See id. (to be codified at 12 C.F.R. $\$ 228.22(b)(5)$ ).

${ }^{187}$ See id. (to be codified at 12 C.F.R. pt. 228, app. A). Although an institution does not need to meet every aspect of each rating profile, see id. (to be codified at 12 C.F.R. pt. 228, app. A (a)(2)), for an "Outstanding" (O) under the Lending Test, the institution must generally have "excellent responsiveness" in this category; for a "high satisfactory" (HS), "good responsiveness"; for a "low satisfactory" (LS), "adequate responsiveness"; for a "needs to improve" (NI), "poor responsiveness"; and for a "substantial noncompliance" (SN), "very poor responsiveness." Id. (to be codified at 12 C.F.R. pt. 228, app. A (b)(1)(i)(A), (ii)(A), (iii)(A), (iv)(A), (v)(A)).

${ }^{188}$ For an $O$ under the Lending Test a "substantial majority" of the institution's loans must be in its assessment area; for an HS, a "high percentage"; for an LS, an "adequate percentage"; for an NI, a "small percentage"; and for an SN, a "very small percentage." Id. (to be codified at 12 C.F.R. pt. 228, app. A (b)(1)(i)(B), (ii)(B), (iii)(B), (iv)(B), (v)(B)).

${ }_{189}$ The distribution must be "excellent" for an O, "good" for an HS, "adequate" for an LS, "poor" for an NI, and "very poor" for an SN. Id. (to be codified at 12 C.F.R. pt. 228, app. A (b)(1)(i)(C)-(D), (ii)(C)-(D), (iii)(C)-(D), (iv)(C)-(D), (v)(C)-(D)). 
economically disadvantaged areas of its assessment area, of low income individuals, or of businesses, ${ }^{190}$ its use of innovative or flexible lending practices in a safe and sound manner to meet the credit needs of low- or moderate-income individuals and geographies, ${ }^{191}$ and its leadership position in community development lending. ${ }^{192}$ Institutions with assets over $\$ 250$ million $^{193}$ must report information on loans covered under the HMDA, on their origination and purchase of small farm and small business loans, and on community development loans originated or purchased. ${ }^{194}$

Like the Lending Test, the "Investment Test" also is intended to reflect the actual deployment of institutional resources into an institution's assessment area. An institution's rating under the Investment Test depends on the amount of "qualified investments $\$ 195$ made by the institution, ${ }^{196}$ the innovativeness and

190 The record must be "excellent" for an $\mathrm{O}$, "good" for an HS, "adequate" for an LS, "poor" for a NI, and "very poor" for an SN. Id. (to be codified at 12 C.F.R. pt. 228, app. $A(b)(1)(i)(E),($ ii $)(E),($ iii $)(E),(i v)(E),(v)(E))$.

${ }_{191}$ "Extensive use" is required for an O, mere "use" for an HS, "limited use" for an LS, "little use" for an NI, and "no use" for an SN. Id. (to be codified at 12 C.F.R. pt. 228, app. A (b)(1)(i)(F), (ii)(F), (iii)(F), (iv)(F), (v)(F)).

192 An institution must be a "leader" in community development lending for an $\mathrm{O}$, or make a "relatively high level of community development loans" for an HS, "an adequate level" for an LS, "a low level" for an NI, and "few, if any" for an SN. Id. (to be codified at 12 C.F.R. pt. 228, app. A (b)(1)(i)(G), (ii)(G), (iii)(G), (iv)(G), (v)(G)).

${ }^{193}$ Small institutions that elect to be evaluated under the Lending Test also must report such information. See infra notes 220-21 and accompanying text; see also Final Regulations, supra note 181 (to be codified at 12 C.F.R. $\$ 228.21(a)(3)$ ) (describing assessment standards for small banks).

${ }^{194}$ See Final Regulations, supra note 181 (to be codified at 12 C.F.R. $\$ 228.42$ ). Reporting on consumer loans is required if the institution wishes consumer loans to factor into the Lending Test. See id. (to be codified at 12 C.F.R. $§ 228.42$ (c)(1)). Regulators abandoned at the last moment a highly controversial requirement that institutions report data on the race and gender of small business and small farm borrowers. See 1994 Proposed Regulations, supra note 181, at 51,282 (proposed app. C). While the costs of complying with the new reporting requirements are at this time a matter of speculation, the new reporting requirements are similar to those imposed under the Home Mortgage Disclosure Act, but encompass a far greater number of types of loans. See supra notes $77-80$ and accompanying text (discussing reporting requirements under the Home Mortgage Disclosure Act of 1974).

195 "Qualified investments" are lawful investments, deposits, membership shares, or grants that have community development as their primary purpose. See Final Regulations, supra note 181 (to be codified at 12 C.F.R. $\$ 228.12(\mathrm{~s})$ ). In addition, any branch that is donated, or sold on favorable terms, or made available on a rent-free basis to certain minority- and female-owned institutions is considered under the Investment Test. See id. (to be codified at 12 C.F.R. $\$ 228.23(d)$ ).

196 The level of qualified investments must be "excellent" with the institution "often in a leadership position" to merit an $O$, "significant" and "occasionally in a leadership position" for an HS, "adequate" but "rarely in a leadership position" for 
complexity of the institution's investments, ${ }^{197}$ and its responsiveness to community credit and community development needs. ${ }^{198}$

Finally, the "Service Test" "evaluates ... the availability and effectiveness of a bank's systems for delivering retail banking services and the extent and innovativeness of its community development services. ${ }^{199}$ Under this test the evaluator assesses the institution's distribution of branches among the geographies it serves, its record of opening and closing branches, the extent to which it makes available alternative systems for delivering banking services to low- and moderate-income geographies and individuals, and the range of the services offered. ${ }^{200}$ In addition, consideration is given to the extent, innovativeness, and responsiveness of the institution's community development services. ${ }^{201}$ The institution's rating under the Service Test hinges upon the accessibility of its services to geographies and individuals in its assessment area, ${ }^{202}$ its record of improving the accessibility of its services (particularly to low- and moderate-income geographies and individuals) by opening and closing branches, ${ }^{203}$ the tailoring of

an LS, "poor" for an NI, and "very poor" for an SN. Id. (to be codified at 12 C.F.R. pt. 228, app. A (b)(2)(i)(A), (ii)(A), (iii)(A), (iv)(A), (v)(A)). Particular consideration is given investments not routinely provided by private investors. See id. (to be codified at 12 C.F.R. $\$ 228.25(c)(2)$.

${ }^{197}$ The innovativeness and complexity of the use of qualified investments must be "extensive" to merit an O, "significant" for an HS, "occasional" for an LS, "rare" for an NI, and no use whatsoever results in an SN. Id. (to be codified at 12 C.F.R. pt. 288, app. A (b)(2)(i)(B), (ii)(B), (iii)(B), (iv)(B), (v)(B)).

${ }_{198}$ The responsiveness must be "excellent" to merit an $\mathrm{O}$, "good" for an HS, "adequate" for an LS, "poor" for an NI, and "very poor" for an SN. Id. (to be codified at 12 C.F.R. pt. 228, app. A (b)(2)(i)(C), (ii)(C), (iii)(C), (iv)(C), (v)(C)).

${ }^{199} \mathrm{Id}$. (to be codified at 12 C.F.R. $\$ 228.24(\mathrm{a})$ ).

${ }^{200}$ See id. (to be codified at $\$ 228.24(\mathrm{~d})$ ).

${ }^{201}$ See id. (to be codified at $\$ 228.24(\mathrm{e})$ ). "Community development services" are those services that have community development as their primary purpose, that are related to the provision of financial services, and that are not otherwise considered under the Service Test. Id. (to be codified at 12 C.F.R. $\$ 228.12(j)$ ).

${ }^{202}$ Service delivery systems must be "readily accessible" to merit an $\mathrm{O}$, "accessible" for an HS, "reasonably accessible" for an LS, "unreasonably inaccessible to portions" of the assessment area for an NI, and "unreasonably inaccessible to significant portions," particularly low- and moderate-income geographies or individuals, for an SN. Id. (to be codified at 12 C.F.R. pt. 228, app. A (b)(3)(i)(A), (ii)(A), (iii)(A), (iv)(A), (v)(A)).

${ }^{203}$ An "improvement" in accessibility must occur to merit an $O$, while the institution's record must not have "adversely affected" accessibility for an HS, have "generally not adversely affected" accessibility for an LS, have "adversely affected" accessibility for an NI, and have "significantly adversely affected" accessibility for an SN. Id. (to be codified at 12 C.F.R. pt. 228, app. A (b)(3)(i)(B), (ii)(B), (iii)(B), (iv)(B), (v)(B)). 
its services to the convenience and needs of its assessment areas, particularly to low- and moderate-income geographies and individuals, ${ }^{204}$ and its leadership position in providing community development services. ${ }^{205}$

After evaluation under each of the tests, determination of the institution's composite CRA rating occurs. To arrive at an institution's overall GRA rating under the four ratings required by the statute, the evaluator applies a point system, ${ }^{206}$ giving the greatest weight to the institution's performance under the Lending Test. ${ }^{207}$ Wholesale and limited purpose institutions ${ }^{208}$ generally are not evaluated under the Lending, Investment, and Service Tests. Rather, these institutions must first request such status in writing from their regulator. ${ }^{209}$ After being designated a wholesale or limited purpose institution, the institution is evaluated under the "Community Development Test," which is intended to evaluate the institution's record in making qualified investments, in community development lending, and in providing community development

${ }^{20+}$ Services must be "tailored" to the needs of the assessment area to merit an $\mathrm{O}$, and must "not vary in a way that inconveniences its assessment area(s), particularly low- and moderate-income geographies and low- and moderate-income individuals" for a rating of HS or LS, depending upon the institution's rating with regard to other service criteria. Id. (to be codified at 12 C.F.R. pt. 228, app. A (b)(3)(i)(C), (ii)(C), (iii)(C)). Services that "vary in a way that inconveniences its assessment area(s), particularly low- or moderate-income geographies or low- or moderate-income individuals" will result in an NI rating, and services that "vary in a way that significantly inconveniences its assessment area(s), particularly low- or moderateincome geographies or low- or moderate-income individuals" will result in an SN rating. Id. (to be codified at 12 C.F.R. pt. 228, app. A (b)(3)(iv)(C), (v)(C)).

${ }^{205}$ The institution must be a "leader" in providing community development services to merit an $\mathrm{O}$, must provide a "relatively high level" of such services for an HS, "an adequate level" for an LS, "a limited level" for an NI, and "few, if any" services for an SN. Id. (to be codified at 12 C.F.R. pt. 228, app. A (b)(3)(i)(D), (ii)(D), (iii)(D), (iv)(D), (v)(D)).

${ }_{206}$ See 60 Fed. Reg. 22,169-70 (1995) (describing in "supplementary information" the procedures used to determine an institution's "composite rating").

${ }^{207}$ See Final Regulations, supra note 181 (to be codified at 12 C.F.R. $\$ 228.28(b)$ ). An $O$ on the Lending Test will result in at least a "satisfactory" overall rating. An $O$ on both the Service and Investment Tests with at least an HS on the Lending Test also will result in an O overall rating. See id. (to be codified at 12 C.F.R. $\$ 228.28$ (b) (1)-(2)). A minimum of an LS on the Lending Test is required to receive an overall rating of "satisfactory." Id. (to be codified at 12 C.F.R. $\$ 228.28(\mathrm{~b})(3)$ ).

208 "Wholesale" institutions are those that are "not in the business of extending home mortgage, small business, small farm, or consumer loans to retail customers." Id. (to be codified at 12 C.F.R. $\$ 228.12(w)$ ). "Limited purpose" institutions are those that offer "only a narrow product line (such as credit card or motor vehicle loans) to a regional or broader market." Id. (to be codified at 12 C.F.R. $\$ 228.12(0)$ ).

${ }^{209}$ See id. (to be codified at 12 C.F.R. $\$ \S 228.12(0), 228.12(w), 228.25(b)$ ). 
services. ${ }^{210}$ Factors that bear on this determination are the number and amount of such investments, loans, and services provided by the institution, ${ }^{211}$ the complexity and innovativeness of those investments, loans, and services, ${ }^{212}$ and the institution's responsiveness to community credit and community development needs. ${ }^{213}$

It is debatable whether the enforcement provisions that accompany the new performance assessment standards are any more stringent than those previously applied. In addition, the final rules evidence a substantial retreat from the enforcement provisions originally proposed in December of 1993. Evidence of discrimination or illegal credit practices will adversely affect the evaluation of an institution's performance, although the effect of such evidence is left vague. ${ }^{214}$ The regulations are not specific as to how an

${ }^{210}$ See id. (to be codified at 12 C.F.R. $\$ 228.25$ (a)); see also supra note 185 (defining community development loans); supra note 195 (defining qualified investments); supra note 201 (defining community development services).

211 See Final Regulations, supra note 181 (to be codified at 12 C.F.R. $\S 228.25(\mathrm{c})(1))$. The level of investments, loans, and services must be "high" for an $\mathrm{O}$, "adequate" for an S, "poor" for an NI, and "few" for an SN. Id. (to be codified at 12 C.F.R. pt. 228, app. A (c)(1)(i), (c)(2)(i), (c)(3)(i), (c)(4)(i)).

${ }^{212}$ See $i d$. (to be codified at 12 C.F.R. $\$ 228.25(c)(2)$ ). Particular attention is given to investments not routinely provided by private investors. Id. The institution must make "extensive use of innovative or complex" investments, loans, or services for an $O$, "occasional use" for an S, "rare use" for an NI, and "no use" for an SN. Id. (to be codified at 12 C.F.R. pt. 228, app. A (c)(1)(ii), (c)(2)(ii), (c)(3)(ii), (c)(4)(ii)).

${ }^{213}$ See id. (to be codified at 12 C.F.R. $\$ 228.25$ (c)(3)). The institution's responsiveness must be "excellent" for an $O$, "adequate" for an $S$, "poor" for an NI, and "very poor" for an SN. Id. (to be codified at 12 C.F.R. pt. 228, app. A (c)(1)(iii), (c)(2)(iii), (c)(3)(iii), (c)(4)(iii)).

${ }^{214}$ See id. (to be codified at 12 C.F.R. $\$ 228.28(c)$ ). Under the final regulations, considerations that come to bear on the institution's rating include the "nature and extent of the evidence, the policies and procedures ... in place to prevent discriminatory or other illegal credit practices," corrective actions the institution has taken or committed to take, and other "relevant information." Id. In contrast, the December 1993 proposals arguably had a much higher threshold for discriminatory practices that would affect an institution's rating. Under that proposal, "evidence that an institution had engaged in illegal discrimination could affect the [institution's] rating," only where an institution had "(1) [e]ngaged in a pattern or practice of illegal discrimination that it has not corrected fully; or (2) [c]ommitted an isolated act of illegal discrimination of which it has knowledge and that it has not corrected fully or is not in the process of correcting fully." December 1993 Proposed Regulations, supra note 11 , at 67,490 (to be codified at 12 C.F.R. $\$ 228.10(\mathrm{~b})$ ). The final rules, then, clearly expand the relevant criteria to include considerations other than "illegal discrimination" as relevant information.

The December 1993 proposal did, however, give discriminatory practices greater effect in the assessment process than do the final rules. In 1993, regulators proposed that any institution that engaged in illegal discrimination and failed to correct the 
institution's rating will factor into the application process. ${ }^{215}$ Attempts of the agencies to enhance their enforcement powers through a provision that an institution receiving an overall rating of "substantial noncompliance" would be subject to enforcement proceedings were found by the Justice Department to be beyond regulators' legal authority and consequently were scrapped late in the revision process. ${ }^{216}$ Also dropped late in the debate was the regulatory equivalent of the "three strikes, you're out" rule, under which an institution that received a "needs to improve" for two consecutive examinations would have received a "substantial noncompliance" rating if its next evaluation resulted in a composite rating of "needs to improve." 217

situation was to receive a rating of less than Satisfactory regardless of its performance on the other tests. See id. The effect of discriminatory practices on the institution's rating has been drastically undercut in the final rules, because the actual effect of such activity upon the institution's rating is not specified.

${ }^{215}$ See Final Regulations, supra note 181 (to be codified at 12 C.F.R. $\$ 228.29$ ) (stating that the institution's rating will be taken into account along with other factors in considering various applications). In contrast, the December 1993 proposals provided concrete standards for the effect that the overall rating would have had on an institution's application:

(i) An "outstanding" rating generally will result in a finding that the CRA aspect of the application is consistent with approval of the application and will receive extra weight in reviewing the application.

(ii) A "satisfactory" rating generally will result in a finding that the CRA aspect of the application is consistent with approval of the application.

(iii) A "needs to improve" rating generally will be an adverse factor in the CRA aspect of the application, and absent demonstrated improvement in the bank's CRA performance or other countervailing factors, generally will result in denial or conditional approval of the application.

(iv) A "substantial noncompliance" rating generally will be so adverse a finding on the CRA aspect of the application as to result in denial of the application.

December 1993 Proposed Regulations, supra note 11, at 67,493 (to be codified at 12 C.F.R. $\$ 228.17(b)(1))$.

${ }^{216}$ See Jaret Seiberg, Agencies Back Off Broadening of CRA Enforcement Powers, AM. BANKER, Dec. 16, 1994, at 1; see also 1994 Proposed Regulations, supra note 181, at 51,274 (providing that a bank receiving a rating of "substantial noncompliance" shall be subject to enforcement orders). Agencies under the old regime had sparingly used the cease and desist order in cases of blatant noncompliance with the CRA, but neither the CRA itself nor the old regulations provide for such an enforcement mechanism, calling into question the propriety of such regulatory action. See supra text accompanying note 151 (discussing rare use of cease and desist orders).

${ }^{217}$ See 1994 Proposed Regulations, supra note 181, at 51,274 (to be codified at 12 C.F.R. $\S 228.28(\mathrm{~d}))$. 


\section{b. Some (Almost) Exemptions}

Regulators faced a difficult situation when presented with requests for relief from the CRA process. Given that the text of the statute offers no leeway to exempt particular types of institutions from the Act, exemptions would be problematic from an administrative standpoint. ${ }^{218}$ Regulators also concluded that exemptions might result in neglect of the credit needs of communities that were served by exempted institutions. ${ }^{219}$ Nonetheless, regulators have allowed two "quasi" exemptions from the general evaluation processes discussed above.

Small retail institutions, ${ }^{220}$ unless they elect to be evaluated under another test, are evaluated by a less stringent method than that discussed above for large institutions. ${ }^{221}$ Under the "Small Institution Performance Standards," the evaluator considers the institution's loan-to-deposit ratio and other lending-related activities, ${ }^{222}$ the percentage of loans and lending-related activities in its assessment area, ${ }^{223}$ its record of lending and engaging in lendingrelated activities to borrowers of different income levels and to businesses and farms of different sizes, ${ }^{224}$ the geographic distribution of its loans, ${ }^{225}$ and its record of taking action on written

${ }^{218}$ See December 1993 Proposed Regulations, supra note 11, at 67,472 (discussing regulators' beliefs that exemptions are not permitted by the statute).

219 See id.

220 "Small" institutions are those institutions with assets of less than $\$ 250$ million that either are independent or are affiliates of a holding company with total assets of less than $\$ 1$ billion. Final Regulations, supra note 181 (to be codified at 12 C.F.R. $\S 228.12(\mathrm{t})$ ). It is estimated that perhaps up to $85 \%$ of the financial institutions covered under the CRA fall in this class. See Cummins, supra note 19, at 3.

221 See Final Regulations, supra note 181 (to be codified at 12 C.F.R. $\$ 228.21(\mathrm{a})(3)$ ) (establishing methods for evaluating small banks).

${ }^{222}$ See id. (to be codified at 12 C.F.R. $\$ 228.26(a)(1)$ ). An institution will receive an $S$ rating if the ratio is "reasonable" viewed in light of the institution's size, financial condition, and the credit needs in its assessment area. Id. (to be codified at 12 C.F.R. pt. 228, app. A (d)(1)(i)).

${ }^{223}$ See id. (to be codified at 12 C.F.R. $\$ 228.26(a)(2)$ ). An institution will receive an $S$ rating if a majority of the institution's loans and activities are in its assessment area. See id. (to be codified at 12 C.F.R. pt. 228, app. A. (d)(1)(ii)).

${ }^{224}$ See id. (to be codified at 12 C.F.R. $\$ 228.26(a)(3)$ ). An institution will receive an $S$ rating if the distribution of loans and activities among income levels and among businesses and farms of different sizes is "reasonable" given the demographics of the institution's assessment area. Id. (to be codified at 12 C.F.R. pt. 228, app. A (d)(1)(iii)).

${ }^{225}$ See id. (to be codified at 12 C.F.R. $\$ 228.26(a)(4)$ ). For an $S$ the geographic distribution must be "reasonable." Id. (to be codified at 12 C.F.R. pt. 228, app. A $(d)(1)(v))$. 
complaints about its performance in meeting community credit needs. ${ }^{226}$ If the institution meets all and exceeds some of the standards for a Satisfactory rating, the institution may earn an Outstanding rating. ${ }^{227}$ Failure to meet the standards results in the possibility of a rating lower than Satisfactory. ${ }^{228}$ Most significantly, small institutions are exempted from loan reporting requirements applicable to other institutions and, accordingly, the costs associated therewith. ${ }^{229}$ Like the tests for retail and wholesale institutions, evidence of discriminatory or illegal practices will adversely affect the rating of the small institution's performance. ${ }^{230}$

Any institution-whether small, large, wholesale, or limited purpose-may opt out of the evaluation procedures otherwise applicable to the institution by submitting a strategic plan for meeting its CRA obligations. ${ }^{231}$ The strategic plan must specify measurable goals for meeting community credit needs through lending, investments, and services, particularly the needs of low- and moderate-income geographies and individuals. ${ }^{232}$ The plan must set forth measurable goals that constitute a Satisfactory performance and may set forth goals that will constitute an Outstanding performance. ${ }^{233}$ If the plan is approved, ${ }^{234}$ the institution's performance will be

${ }^{226}$ See id. (to be codified at 12 C.F.R. $\$ 228.26$ (a)(5) and at 12 C.F.R. pt. 228, app. A (d)(1)(iv)).

${ }_{227}$ See id. (to be codified at 12 C.F.R. pt. 228, app. A (d)(2)). The small institution's qualified investments and service may be considered. See id.

${ }^{228} \mathrm{See}$ id. (to be codified at 12 C.F.R. pt. 228, app. A (d)(3)). Whether an NI (needs to improve) or SN (substantial noncompliance) is given depends on the degree to which the small institution's performance fails to meet the criteria required for a satisfactory rating. See id.

${ }^{229} \mathrm{See}$ id. (to be codified at 12 C.F.R. $\$ 228.42(\mathrm{a})$ ).

${ }^{230}$ See id. (to be codified at $\$ 228.28$ (c)); see also supra note 214 and accompanying text (discussing the import of discriminatory practices on the ratings of other institutions).

${ }^{231}$ See Final Regulations, supra note 181 (to be codified at \$§ 228.21(a)(4), 228.27). The plan may not have a term of longer than five years, and multi-year plans must include annual interim measurable goals for assessing performance under the plan. See id. (to be codified at 12 C.F.R. $\$ 228.27(c)(1)$ ).

${ }^{232}$ See id. (to be codified at 12 C.F.R. $\left.\$ 228.27(f)(1)(\mathrm{i})\right)$. Each institution's plan must address all three performance categories (lending, investment, and service), but retail institutions must emphasize their plans' proposed lending and lending-related activities. See id. (to be codified at 12 C.F.R. $\$ 228.27(f)(1)(i i)$ ). However, a variation in emphasis may be acceptable depending upon community characteristics and credit needs, as well as the institution's capacity, constraints, product offerings, and business strategy. See id.

${ }^{233}$ See id. (to be codified at 12 C.F.R. $\$ 228.27(f)(3)$ ).

${ }^{231}$ The institution first must seek both informally and formally public suggestions 
measured by whether the institution has substantially met or exceeded the plan's goals. ${ }^{235}$ Failure to meet substantially the plan's goals for satisfactory performance will result either in a less than satisfactory grade ${ }^{236}$ or in evaluation under the regulatory assessment standards otherwise applicable to the institution. ${ }^{237}$ Election of evaluation under a strategic plan does not exempt the institution from data- reporting requirements to which it is otherwise subject. ${ }^{238}$ And, again, evidence of discriminatory or illegal practices will adversely affect an institution's rating under the strategic plan option. ${ }^{239}$

Thus, although no institution will be truly "exempt" from the CRA evaluation process, some leeway exists for institutions to be evaluated by a less rigorous procedure. The number of institutions that might consider such an election can only be a matter of conjecture until the final rules are fully in effect and the regulatory attitudes toward the new evaluative procedures are capable of being assessed. Quite obviously, smaller institutions have an incentive to remain with the extremely lenient small institution performance standards. Given that retail, wholesale, or limited purpose institutions that elect the strategic plan option obtain no cost savings

and comments on the plan. See id. (to be codified at 12 C.F.R. $\$ 228.27(d)$ ). The plan then must be submitted to the institution's regulator at least three months prior to the plan's proposed effective date, together with comments received from the public. See id. (to be codified at 12 C.F.R. $\$ 228.27(\mathrm{e})$ ). In evaluating the plan's goals, regulators are to consider public involvement in formulating the plan and, as appropriate, (i) the extent and breadth of lending and lending-related activities, (ii) the amount, innovativeness, complexity, and responsiveness of qualified investments, (iii) the effectiveness and availability of the institution's services, and (iv) the extent and innovativeness of the institution's community development services. See id. (to be codified at 12 C.F.R. $\$ 228.27(\mathrm{~g})(2)-(3))$. Overall, the plan's measurable goals shall be considered Satisfactory if the goals "adequately help" meet community credit needs and shall be considered Outstanding if the goals "substantially exceed" the levels approved as satisfactory. Id. (to be codified at 12 C.F.R. pt. 228, app. A (e)(1)(2)).

${ }^{235}$ See id. (to be codified at 12 C.F.R. pt. 228, app. A (e)(3)(i)-(ii)). An Outstanding rating is available under the strategic plan option only if the plan contains goals for both Satisfactory and Outstanding ratings. See id. (to be codified at 12 C.F.R. $\S 228.27(f)(3))$.

${ }^{236}$ See id. (to be codified at 12 C.F.R. pt. 228, app. A (e)(3)(iii)).

${ }^{237}$ See id. The institution must elect to be evaluated under the method otherwise available to it at the time the institution submits its initial plan for regulatory approval. See id.

${ }^{238}$ See id. (to be codified at 12 C.F.R. $\$ 228.27(\mathrm{~b})$ ).

${ }^{239}$ See id. (to be codified at 12 C.F.R. $\$ 228.28(c)$ ); see also supra note 214 and accompanying text (discussing the effect of discriminatory practices in the tests otherwise applicable to the institutions). 
through reduced reporting requirements, the incentive to adopt a plan would vary among institutions. Those with less than outstanding records and expansion aims, for example, have a great incentive to adopt a plan, particularly if regulators indicate a willingness to approve plans without extensive scrutiny of the plan's content. Compliance with the plan might undermine community group protests at the application stage. In addition, the plan option might be a more effective means of securing a high CRA rating than lending, investments, services, or community development lending under the standard tests. Finally, the certainty generated through evaluation under a plan provides a modest incentive for plan adoption irrespective of an institution's rating.

\section{Change ... or More of the Same?}

While the criteria under the new performance tests appear at first glance to be much more objective and quantifiable than the efforts-based enforcement regime, the revised evaluative process can be viewed nonetheless as a potential source of arbitrary evaluations-the precise complaint levied against the old regime. ${ }^{240}$ Although enforcement now clearly focuses on the types of activities that merit CRA credit, the overall rating process still evokes a great deal of regulatory discretion. For example, given that a large institution's CRA rating hinges upon an evaluator's determination that the institution's performance under the myriad of factors directed by the Lending, Investment, and Service Tests is "excellent," "good," "adequate," "reasonable," "poor," or some other qualitative determination, ${ }^{241}$ a great deal of subjectivity still threatens to enter into, if not control, evaluations. In addition, the regulations provide that all assessments of performance are to be made in "context," focusing on safety and soundness considerations and the individual institution's assessment area, business focus, and capacities. ${ }^{242}$ Finally, in spite of the evaluation procedures' initial

${ }^{240}$ Of course, until the new enforcement regime is fully implemented, it is impossible to tell with any certainty how consistent regulators will be with their examination process. A).

${ }^{241}$ See Final Regulations, supra note 181 (to be codified at 12 C.F.R. pt. 228, app.

${ }^{242}$ See $i d$. (to be codified at 12 C.F.R. $\$ 228.21(b)$ ). The tests and standards are to be applied in the context of the following information:

(1) Demographic data on median income levels, distribution of household income, nature of housing stock, housing costs, and other relevant data pertaining to [an institution's] assessment area(s); 
focus on actual lending, investments, and service, regulators have indicated that the CRA does not require an institution to abandon safety and soundness in the name of actual results. ${ }^{243}$

When an institution is "good" or "innovative" given the "context," when an institution is a "leader" in the cause of community development given the "context," or when safety and soundness considerations warrant overlooking otherwise poor results are questions that remain unanswered. It is hard to see how such determinations can be made other than subjectively. The textual vagueness of the rating provisions and the discretion vested in agencies to assess the performance in the proper context caution an institution both actively to engage in, and to maintain detailed records of, its outreach and marketing efforts to its community, particularly in low- and moderate-income geographies, in the event that its evaluation, if based upon actual loans made or not made, were to point toward a poor rating. Such records would help to prove that the institution had actively searched and examined its relevant market and found demand or the opportunity to make suitable, safe loans lacking. Accordingly, the new evaluative procedures hazard the same inconsistencies and subjectivity of the old regime, and any shift from efforts to results is a rather deceptive one.

Nor can the move toward results be said to reduce substantially the paperwork burden imposed on regulated institutions or the

(2) Any information about lending, investment, and service opportunities in the [institution's] assessment area(s) maintained by the [institution] or obtained from community organizations, state, local, and tribal governments, economic development agencies, or other sources;

(3) The [institution's] product offerings and business strategy as determined from data provided by the [institution];

(4) Institutional capacity and constraints, including the size and financial condition of the [institution], the economic climate (national, regional, and local), safety and soundness limitations, and any other factors that significantly affect the [institution's] ability to provide lending, investments, or services in its assessment area(s);

(5) The [institution's] past performance and the performance of similarly situated lenders;

(6) The [institution's] public file . . . and any written comments about the [institution's] CRA performance submitted to the [institution] or [the regulator]; and

(7) Any other information deemed relevant by [the regulator].

Id.

${ }^{243}$ See id. (to be codified at 12 C.F.R. $\$ 228.21(d)$ ) (indicating that these regulations "and the CRA do not require a[n institution] to make loans or investments or to provide services that are inconsistent with safe and sound operations"). 
costs of compliance with the CRA, two principal concerns under the efforts-based regime. Rather, a results-based regime may in fact bring significant enforcement costs. Institutions subject to the new data reporting requirements face new compliance costs. Regulatory enforcement costs are sure to rise to accommodate the data reporting requirements. ${ }^{244}$ Moreover, as stated above, even further paperwork and record-keeping is advisable to ensure adequate information that bears on the "context" of the institution's business and local market. Finally, the new regulations fail in any meaningful respect to strengthen regulators' ability to enforce compliance with the Act.

Admittedly, any assessment of the efficacy of a results-based regime must await full implementation and an empirical evaluation of the regime's costs and benefits. It is questionable, though, whether the new evaluation and enforcement procedures based upon results will substantially reduce paperwork, evoke consistent or more differentiating ratings, or, given the malleability of the evaluation procedures, even lead to increased community lending overall. Arguably, gains, if any, in actual lending under the Lending Test for larger institutions may be offset by the leniency given to small institutions under the Small Institution Performance Standards. The much-anticipated call to move away from efforts and toward results might very well accomplish little in curing the problems that have plagued the CRA since its enactment. It seems patent that the more we seek to change the GRA, the more its claimed deficiencies stay the same, and perhaps even flourish. The struggle to achieve the basics of CRA implementation ${ }^{245}$ still continues.

Accordingly, irrespective of whether the debate is framed in terms of efforts or results, much of the critique that was discussed at the beginning of this section ${ }^{246}$ seems at least superficially to ring true. The CRA substantially intervenes in the affairs of covered institutions and imposes substantial costs on those institutions. Yet, whether it justifiably does so is another question entirely. It is not this Article's purpose to decry the flawed process that begot the $\mathrm{CRA}^{247}$ or to examine the practical and theoretical political

${ }^{244}$ Costs of implementation include training of examiners and assembling and synthesizing of data generated under the new regime.

${ }^{245}$ See supra text accompanying note 1.

246 See supra text accompanying notes 48-66.

${ }^{247}$ For a discussion of the flawed legislative methodology in the context of the 
implications of the CRA as it now stands or has developed. Rather, this Article turns to a somewhat more mundane, yet prescriptive, issue: refining and resolving the issues that the legislative debate, the years of CRA enforcement, and the proposals to revise the means of enforcement have failed to address satisfactorily. The next Part addresses whether the CRA is even warranted. If it is not, the CRA experiment set forth above-however socially admirable or politically appealing-should be abandoned.

\section{JUSTIFYING "COMMUNITY REINVESTMENT"}

The core of the CRA debate lies in the Act's somewhat blithe assertion that regulated financial institutions have an obligation to meet community credit needs. Current dialogue about whether the CRA has a justifiable purpose seeks either to reject this premise or to champion it. Accordingly, the defense or critique of the CRA rages at two sharply divergent poles, with little room for reconciliation between the two. On the one hand, the banner of "antilocalism" has been raised to reject the essential precept of the CRA that institutions have some sort of obligation to their local communities. ${ }^{248}$ In contrast, an emerging communitarian, "community rights" perspective on the Act and on financial institution regulation seeks to establish a framework for critiquing the CRA's effectiveness based upon community. ${ }^{249}$

As will be argued in this section, both the antilocalist and communitarian positions are unpersuasive. Continued dialogue between these poles is misguided and threatens only to perpetuate the CRA's failings. In place of the conceptually flawed debate between antilocalism and communitarianism, then, the following discussion draws upon the antiredlining underpinnings of the CRA to advance a theory of equality of access and opportunity that defends the Act. ${ }^{250}$

Truth-in-Lending Act, see Edward L. Rubin, Legislative Methodology: Some Lessons from the Truth-in-Lending Act, 80 GEO. L.J. 233, 233-34 (1991) (arguing that the failure of the Truth-in-Lending Act to achieve its declared goals was due to the lack of an effective methodology for the design of regulatory legislation).

${ }^{248}$ See infra part II.A.

${ }^{249}$ See infra part II.B.

${ }^{250}$ See infra part II.C. 


\title{
A. The Antilocalism Challenge
}

The antilocalism critique of the CRA asserts that the Act erroneously embodies "the proposition that depository institutions owe special obligations to their local communities. ${ }^{251}$ The notion that localism reflects an "outdated" ideology 252 of banking law rests on three underlying, assertedly flawed, propositions: that banking is a local industry, that banks drain credit out of local communities, and that "banks owe special duties to their local communities. ${ }^{253}$ According to Professors Macey and Miller:

\begin{abstract}
A basic theme underlying the ideology of the CRA is the proposition that banks are fundamentally local institutions: they take deposits from the local community and return those funds to the community in the form of loans. Alternatively, the proposition is that banks should be local institutions, even if they sometimes behave as if they are not. ${ }^{254}$
\end{abstract}

Although the notion of community banking and community bankers might have had a ring of truth to it earlier in history-fueled by "American folklore" 255 -the evolution and growth of banking institutions into national financial institutions have undermined the local character of banking institutions. ${ }^{256}$ Not only does the "fundamentally local" articulation of the banking industry fail to adequately describe the current system of banking law under the antilocalist critique, it fails on normative grounds as well. ${ }^{257}$ The

${ }^{251}$ Macey \& Miller, supra note 27, at 303. Localism as an underlying theme in banking law is also reflected in several U.S. Supreme Court decisions. See id. \& n.43 (citing Lewis v. BT Inv. Managers, Inc., 447 U.S. 27, 38 (1980) and Northeast Bancorp v. Board of Governors of the Fed. Reserve Sys., 472 U.S. 159, 177 (1985)).

252 Id. at 303 .

${ }^{253}$ Id. at 304. For a fuller discussion of these propositions, see id. at 303-12.

${ }^{254}$ Id. at 304 .

${ }^{255} \mathrm{Id}$. In attempting to distinguish fact from fiction, and law from film, this Article will not analyze the CRA and its underpinnings by a debate over the aesthetics and accuracy of Frank Capra's film It's $A$ Wonderful Life. Cf. Macey \& Miller, supra note 27, at 304 (suggesting that George Bailey, the building and loan president in It's $A$ Wonderful Life, is a rhetorical part of American folklore); Taibi, Communitarianism and Banking Regulation, supra note 30, at 1109 (mourning the demise of communitybased institutions like the Bailey Building \& Loan Association in It's A Wonderful Life). One questions whether a post-War fable-albeit a Christmastime classic-provides support for government intervention into the affairs of regulated financial institutions.

${ }^{256}$ See Macey \& Miller, supra note 27, at 304-07 (describing how the movement of banks away from localism has weakened the ties that connect banks with their immediate local communities).

${ }^{237} \mathrm{See} i d$. at 307 (indicating that it is difficult to justify a normative preference for 
economic benefits that have accrued to consumers and to the financial health of banks as a result of the delocalization of banks render any claim for a return to banking as a local industry indefensible "on persuasive normative terms. ${ }^{258}$ Economic arguments, therefore, compel a regulatory policy that will move the financial services industry away from its antiquated localist beginnings. Those arguments overshadow any other normative justifications for the CRA. According to Professors Macey and Miller, however, the CRA compels precisely that return to localism.

The full parameters of the antilocalist objections to the GRA merit explication. The commercial banks ${ }^{259}$ and other institutions regulated under the CRA are a key, but small, segment of the variety of financial institutions in our society. ${ }^{260}$ Historically, institutions covered by the CRA have had a more geographically localized presence than other institutions, and, therefore, provided the principal source of capital to their communities. Banks and other regulated institutions act, in economic terms, as financial intermediaries. Commercial banks, for example, fulfill a channeling function for capital by taking deposits from investors and reinvesting those deposits in commercial loans. High transaction costs and imperfect information often prevent the direct flow of capital from one investor to another. ${ }^{261}$ Intermediation acts to reduce these costs and informational deficiencies by substituting otherwise prohibitive direct investment with the financial institution's expertise in identifying and broadening investment opportunities.

Financial intermediation, so conceived, has both defined-at least historically-the market of commercial banks and also inured to the benefit of both local depositors as well as borrowers. Banks acquired a comparative market advantage through their expertise in assessing the credit risk of their borrowers and, therefore, lowered the potential risk associated with an investment opportunity. ${ }^{262}$

localism, because the movement away from localism has generally benefitted consumers).

${ }^{258} I d$.

${ }^{239}$ Because commercial banks are the most significant type of entity regulated under the CRA, the following discussion will generally refer to banks.

${ }^{260}$ For example, the CRA does not cover insurance companies, investment banking or securities firms, mutual funds, or pension funds, all of which are "financial institutions." See supra note 34 (discussing the scope of the CRA).

${ }^{261}$ See Jonathan R. Macey \& Geoffrey P. Miller, America's Banking System: The Origins and Future of the Current Crisis, 69 WASH. U. L.Q. 769, 770 (1991) (stating that intermediaries between investors are important to an economy that exists in a world with imperfect information and nonmarginal transaction costs).

${ }^{262}$ See Gruben et al., supra note 26 , at 28 (noting that "[t]he extent to which [the] 
Because most depositors lack either the information or the desire to make this risk assessment on their own behalf, they are able to employ the bank to identify profitable investment opportunities. ${ }^{263}$ Similarly, depositors may take advantage of the investment opportunities presented in larger commercial loans by combining their funds with other banks and other depositors. They therefore obtain the benefits of larger investments than they would have been able to make on their own, while retaining the liquidity of their investment. ${ }^{264}$ Depositors also benefit from the bank's expertise in loan monitoring and portfolio diversification. Bank monitoring of individual loans reduces the default risk associated with any one particular borrower. ${ }^{265}$ The institution's ability to diversify its portfolio and thereby offset the inherent default risks of individual loans in the overall portfolio also reduces the overall risk assumed by any one individual depositor. ${ }^{266}$

Banks' expertise in assessing credit risk historically benefited potential borrowers as well. Not only do banks offer borrowers a source of capital but, more importantly, they are also able to value otherwise illiquid assets owned by borrowers and make loans collateralized by those assets. ${ }^{267}$ Borrowers, therefore, are able to convert their otherwise illiquid assets into liquid assets. ${ }^{268}$ In addition, institutional expertise in monitoring facilitates borrowing by reducing the default risk associated with any particular loan.

monitoring [of creditworthiness] is not performed easily or as efficiently by other participants in the credit markets determines the market share of banking relative to direct placement activity"); Macey \& Miller, supra note 261, at 770-72 (stating that '[b]anks' ability to sell their skill at valuing assets, their ability to allow investors and borrowers to realize economies of scale in investing, and their ability to convert illiquid investments into liquid investments all explain why banks have survived and prospered").

${ }^{263}$ See Macey \& Miller, supra note 261, at 771 (recognizing that "[b]y placing their money in a bank, depositors in effect hire the bank to use its know-how in identifying good investment opportunities").

${ }^{25+}$ See id. (noting that "banks allow depositors to take advantage of economies of scale that otherwise would place many good investment opportunities out of the grasp of ordinary investors").

${ }^{265}$ See Gruben et al., supra note 26, at 28 (noting that bank monitoring "ensure[s] prudent behavior on the part of borrowers").

${ }^{265}$ See id. (stating that banks can reduce default risks by diversifying their portfolios, and noting that such portfolios are generally less risky than undiversified ones).

${ }^{267}$ See Macey \& Miller, supra note 261, at 771 (stating that "banks improve the operation of the economy by investing in portfolios of illiquid assets and by offering depositors liquid claims (deposits) on the banks' own assets").

${ }^{268}$ See id. at 772. 
The extent to which this depiction accurately describes the modern lending institution is becoming more and more questionable due to developments in financial markets and technology, as well to the increasingly national and international scope of our economy. ${ }^{269}$ Such changes have undermined not only any deposit monopoly that the traditional local depository institution may have once had in its service area, ${ }^{270}$ but also the competitiveness of some of the products offered by that institution. For example, commercial banks now face a greater amount of competition from other financial institutions such as pension funds, insurance companies, and mutual funds. ${ }^{271}$ Such institutions not only attract funds from depositors that, in the past, might have gone to the local bank or thrift, but also offer credit products that compete with the larger commercial bank loan. The expanding debt and equity security markets compound the problem of an eroding deposit base by attracting borrowers away from commercial banks as a source of capital. ${ }^{272}$ Similarly, asset securitization, some have claimed, has threatened a significant portion of commercial banks' traditional lending market. ${ }^{273}$ Securitization not only has superior ability in

${ }^{269}$ See, e.g., JAMES L. Pierce, The Future OF BANKING 79-87 (1991) (explaining how banks are becoming less "banklike" and more like other purveyors of financial services in response to a changing financial environment); Keith R. Fisher, Reweaving the Safely Net: Bank Diversification into Securities and Insurance Activities, 27 WAKE FOREST L. REV. 123, 130-36 (1992) (discussing the ways in which technology and advances in financial markets have contributed to homogenization of the U.S. financial markets); Stephen J. Friedman \& Connie M. Friesen, A New Paradigm for Financial Regulation: Getting from Here to There, 43 MD. L. REV. 413, $414-42$ (1984) (discussing the evolution of the commercial bank); Jonathan R. Macey, The Inevitability of Universal Banking, 19 BROOK. J. INT'L L. 203, 206-11 (1993) (discussing the effect that technology change has had on the competitiveness of commercial banks); Macey \& Miller, supra note 261, at 772-81 (discussing the decline in the commercial banks' role as a financial mediator).

${ }^{270}$ See Fisher, supra note 269, at 130 (noting the banks' and thrifts' historic monopoly on deposit-taking and commercial and mortgage loans); Macey \& Miller, supra note 261, at 774 (discussing the eroding market share of the commercial bank).

${ }^{271}$ See, e.g., Phillip R. Mack, Recent Trends in the Mutual Fund Industry, 79 Fed. Res. Bull. 1001, 1001 (1993) (addressing the diversion of bank deposits to the mutual fund industry).

${ }^{272}$ See PIERCE, supra note 269 , at 83 (noting that banks' role as position-taking intermediaries is diminishing due to the technological improvements and increased financial education that have made it far easier for other types of institutions to lend money directly); Macey \& Miller, supra note 261, at 772-73 (noting that the "development of robust capital markets for equity and debt securities" reduces the need to use banks as financial intermediaries).

${ }^{273}$ See Macey \& Miller, supra note 261, at 774 (noting that “[m]ore efficient market segments have been able to securitize themselves and thereby avoid more costly 
providing liquidity to otherwise illiquid assets, ${ }^{274}$ but also results in substantially lower monitoring costs than commercial lending. ${ }^{275}$

The increasing competition that regulated financial institutions face in attracting depositors and in providing competitive products to borrowers is enhanced by, and interrelated with, technological developments and an increasingly national network of financial service providers. For example, although informational constraints might once have limited depositors largely to their local bank or thrift, depositors now have sufficient information to invest their funds in a mutual fund in another part of the country-a fund that most likely offers some of the same, and perhaps more attractive, services as the local hometown bank. ${ }^{276}$ Increased access to information has also enabled some individual and many corporate borrowers to identify nonlocal sources of capital that, as mentioned above, are frequently less costly than loans from a nearby bank or thrift. Technological advances reduce the inconveniences that may arise from dealing with geographically distant financial institutions.

Thus, increased competition, decreased information costs, and the emerging national market for financial services have encouraged an antilocalist call for recasting our approach toward regulating traditional depository institutions. ${ }^{277}$ That the CRA forces institu-

commercial loan markets"). For a discussion of the emerging field of asset securitization, see Joseph C. Shenker \& Anthony J. Colletta, Asset Securitization: Evolution, Current Issues and New Frontiers, 69 TEx. L. REv. 1369 (1991). Banks and thrifts have been able to engage in a number of types of securitization transactions. See, e.g., id. at 1388-96 (addressing the reasons for and results of the securitization of assets by banks and thrifts); see also PIERCE, supra note 269, at 84-87 (describing generally the process of securitization by banks).

A number of legal impediments, however, principal among them the GlassSteagall Act, impede depository institutions' ability to compete effectively with other financial institutions in the field of asset securitization and in the underwriting of debt and equity securities. See Shenker \& Colletta, supra, at 1413-21.

274 See Shenker \& Colletta, supra note 273, at 1374-75 (noting that securitization ensures greater liquidity than traditional lending).

275 See Macey \& Miller, supra note 261, at 775 (noting that the monitoring costs involved in securitization are lower than those in the banking industry); Shenker \& Colletta, supra note 273, at 1394-95 (noting that securitization permits a bank or thrift to reallocate its credit risk exposure with respect to the securitized asset, thereby reducing the need for continuous monitoring after the credit is granted).

276 See PIERCE, supra note 269 , at 83 (noting that technological improvements have lowered the costs of information and transactions and thus caused a change in investment patterns); Mack, supra note 271, at 1001 (noting that "as intermediaries competing with banks and thrift institutions, mutual funds have contributed to the reduction of the role of these depositories as providers of credit").

${ }^{277}$ See generally supra note 269 (citing sources that question the localist conception 
tions to remain to some extent local industries renders the Act unwarranted and bad policy. Nonetheless, a great deal of evidence suggests that at least with respect to most ordinary consumers and small- and medium-sized businesses, the traditional depository institution still plays an important role in its local service area.

Most households still rely predominantly upon local financial depository institutions such as commercial banks, savings and loans, and credit unions for the provision of financial services. ${ }^{278}$ Although the market for consumer mortgage credit has become increasingly less geographically local, more than three-quarters of household mortgages are at local institutions. ${ }^{279}$ As suppliers of both credit and deposit services to households, local financial intermediaries still maintain their traditional role. ${ }^{280}$

Local commercial banks are also the predominant supplier of financial services to small- and medium-sized businesses. ${ }^{281}$ Although nonlocal, nonbank financial intermediaries have acquired some of the market for particular credit services such as leasing, ${ }^{282}$ local commercial banks remain a major source of credit for smalland medium-sized businesses. ${ }^{283}$ Furthermore, these are not oneshot transactions. Rather, the local institution is the primary institution for such businesses and provides more than one service for its customers. ${ }^{284}$

of finance).

${ }^{278}$ See Gregory E. Ellichausen \& John D. Wolken, Banking Markets and the Use of Financial Services by Households, 78 Fed. Res. Bull. 169, 173 (1992) (noting that "depository institutions provide 83 percent of the accounts used by households [and that] the overwhelming majority of these accounts are obtained locally").

${ }_{279}$ See id. at 176 (reporting that for checking and savings accounts, IRAs, bank credit cards and mortgages, among other financial services, "the median distance to offices of financial institutions is ten miles or less").

${ }^{280}$ See $i d$. at 174,176 (noting that local financial institutions are the primary suppliers of household deposit and credit services); see also Arthur B. Kennickell \& Martha Starr-McCluer, Changes in Family Finances from 1989 to 1992: Evidence from the Survey of Consumer Finances, 80 Fed. Res. Bull. 861, 879 tbl. 12 (1994) (noting that commercial banks remain the largest supplier of consumer debtor services).

${ }^{281}$ See Gregory E. Elliehausen \& John D. Wolken, Banking Markets and the Use of Financial Services by Small- and Medium-Sized Businesses, 76 Fed. Res. Bull. 801, 808 (1990) (noting that small- and medium-sized firms use commercial banks as their primary financial institution).

${ }_{282}$ See id. at 810 tbl. 7 (providing survey results indicating the types of financial institutions used by small- and medium-sized firms, and the extent to which the firms use the institutions).

${ }^{283}$ See id.

284 See id. at 808 . Evidence indicates generally that nonbank or nonlocal suppliers are tapped infrequently and usually only for a single financial service. See id. 
Accordingly, a tension exists between the antilocalists' claim that the local depository institution is an emerging anachronism and the accumulated evidence that illuminates those institutions' profound role even today in meeting local credit needs. Increased competition posed to local institutions by nonlocal or nonbank financial intermediaries may very well have significantly transformed the market for credit services provided to large firms. Evidence also suggests that nonbank mutual funds have diverted significant household, business, and government deposits away from banks. ${ }^{285}$ Yet, that households and small- and medium-sized firms still rely significantly on local depository institutions for their deposit and credit needs indicates that such a transformation has yet to emerge in all areas. At least with respect to households and small and medium-sized businesses, the costs that would be incurred in identifying nonlocal providers of financial services and products render the local institution the predominant supplier of financial services. ${ }^{286}$

Although the economic account of financial intermediation and the antilocalist critique of the CRA suggest a shift in regulatory policy away from the traditional conceptualization of the local depository institution, reliance upon the account as support for repeal of the CRA evokes two related hazards. First, given that most households and small and medium-sized businesses obtain their financial services from local institutions, much of the descriptive power of antilocalist argument against the CRA falters. It is difficult to think of the CRA as mandating a "return" to local banking when most institutions have yet to leave their local niche. Any shift, then, is overstated or at least premature. Advocating

285 See Kennickell \& Starr-McCluer, supra note 280 , at 867 (stating that data on family finances "show a large decrease in [families'] ownership of certificates of deposit . . . along with a strong offsetting rise in ownership of mutual funds"); Mack, supra note 271 , at 1012 (stating that mutual funds challenge the traditional role of banks by offering "an important investment option for household savings and an important funding source for corporations and state and local governments"). Federal law significantly restricts, but does not entirely preclude, bank participation in the mutual fund industry. See id. at 1009-11.

${ }^{286}$ See Elliehausen \&.Wolken, supra note 278, at 174 (noting that "[t]he high percentage of local institutions [used] for the [household] main checking account suggests that transaction costs may indeed make nonlocal institutions imperfect substitutes for at least some financial services"); Elliehausen \& Wolken, supra note 281 , at 805 (noting that search costs are one factor that leads to small, rather than large, firms to use services provided by local institutions). 
repeal of the CRA by reference to the assertedly nonlocal character of the modern financial institution is a highly debatable claim.

Beyond the descriptive shortcomings of the antilocalist argument against the CRA lies a more fundamental weakness. Even to the extent that the shift from a local to a national character adequately depicts today's financial services industry, reconceptualizing the nature and extent of legal intervention on the basis of such a shift has significant social and cultural implications that the economic account of intermediation fails to address. The antilocalist, economic argument against the CRA assumes that local areas will somehow effectively be served in the absence of the CRA, most probably through the market, and thus implicitly recognizes and validates the normative importance of access to financial services. The vitality of this assumption is problematic when viewed historically. The premise that, absent the CRA, areas with demand for credit or deposit services will be served by existing institutions or by other forms of institutions that will step in to fill the gap is contingent upon the existence of a freely functioning market unaffected by biases or other informational constraints. Yet, the tortured history of the effort to check credit discrimination suggests that this condition has not been present historically, and recent evidence strongly compels the view that it does not exist today. ${ }^{287}$ Given this, the antilocalist argument against the CRA, in addition to being descriptively questionable, fails on prescriptive grounds as well. Although implicitly recognizing the importance of access to credit, its necessary precondition of a market to provide universal access is an invention out of touch with historical reality.

This is not to say that the economic, antilocalist critique of the CRA lacks merit or, more mildly, is not instructive. Credit discrimination in many cases results from unintentional biases or other kinds of imperfect or incomplete information rather than from intentional, invidious discrimination. ${ }^{288}$ The costs to the

\footnotetext{
${ }^{287}$ See supra note 80 and accompanying text (discussing data collected under the HMDA and showing racial disparities in loan denial rates).

${ }^{288}$ See, e.g., SUSAN E. RodbuRG \& Richard C. WALKER, III, FEderal RESERVE Bank of Boston, Closing the GaP: A Guide to EQUal OpPoRTunity Lending (1993) ("Overt discrimination in mortgage lending is rarely seen today. Discrimination is more likely to be subtle, reflected in the failure to market loan products to potential minority customers and the failure of lenders to hire and promote staff ...."); $c f$. Edward J. McCaffery, Slouching Towards Equality: Gender Discrimination, Market Efficiency, and Social Change, 103 YALE L.J. 595, 634 (1993) ("Small initial discriminations, even if entirely rational, can easily lead to a situation wherein severe discrimination is rampant[,] ... without any extra-market assumptions or dark
} 
financial services industry under the CRA and the anticompetitive effects that government intervention may have are certainly factors that should weigh into the calculus of the appropriate scope of legislative intervention. Rather, the economic antilocalist argument does not by itself persuasively dictate repeal of the CRA.

\section{B. A Communitarian Defense}

The name of the Act itself-Community Reinvestment-suggests a perspective on the CRA based upon community, community rights, or community empowerment that is subtly grounded in communitarian theory, ${ }^{289}$ although the full scope of the communitarian position remains, as yet, vague. As a matter of general political theory, communitarianism substitutes the liberal emphasis on the individual with a focus upon community, presumably as the basis for determining the proper scope of legal rights and duties. ${ }^{290} \mathrm{~A}$ defense of, or critique of, communitarian theory and the communitarian state is beyond the scope of this Article. While as yet not fully developed, a communitarian perspective on the CRA would seek to normatively justify the CRA and, more importantly, would provide a framework for advancing an enforcement scheme for the CRA or for critiquing existing enforcement efforts. However, the communitarian position has a number of flaws that call into question its validity as a justification for regulatory intervention.

Communitarian theory applied to financial institution regulation attempts to positively reconstruct the antilocalist critique discussed in the previous section. ${ }^{291}$ The very general communitarian

conclusions about human nature.").

${ }^{289}$ See generally Taibi, Community Economic Empowerment, supra note 30 (examining the structure of the financial system from a community empowerment viewpoint); Taibi, Communitarianism and Banking Regulation, supra note 30, at 1107, 1114-17 (same).

${ }^{290}$ See, e.g., Wendy Brown-Scott, The Communitarian State: Lawlessness or Law Reform for African-Americans, 107 HARV. L. REV. 1209, $1217-22$ (1994) (discussing competing visions of communitarianism and of a communitarian state); Allen $\mathrm{E}$. Buchanan, Assessing the Communitarian Critique of Liberalism, 99 ETHICs 852, 855-61 (1989) (discussing pillars of communitarianism); see also Stephen A. Gardbaum, Law, Politics, and the Claims of Community, $90 \mathrm{MICH}$. L. REv. 685, 687 (1992) ("[W]hat it means to be a communitarian in the law remains extremely opaque.").

${ }^{291}$ Claims of community frequently are met with the rather pejorative rejoinder of "localism." See, e.g., Joseph L. Sax, Do Communities Have Rights? The National Parks as a Laboratory of New Ideas, 45 U. PITT. L. REV. 499, 500-01 (1984) ("[O]ur notion of community is strongly tied to localism, and the chips are strongly stacked against localism in American law."). 
position on the CRA might begin:

Local communities ought to receive special treatment from local financial institutions in the provision of credit because those institutions have an obligation to serve the needs of their community. Financial institutions are not (or should not be viewed as) autonomous, self-interested actors responsive solely to the vagaries of the market. Rather, they are cultural, social and political participants in community life. The recognition by Congress in the preamble to the CRA that institutions "have [a] continuing and affirmative obligation to help meet the credit needs of the local communities in which they are chartered ${ }^{\text {292 }}$ not only incorporates this position but also is correct.

The debate over "disinvestment" which led to enactment of the CRA embodies the communitarian premise that communities have a right to ample credit from their local financial institution. ${ }^{293}$ A requirement of "reinvestment" by local institutions subtly supports the communitarian notion that communities should be serviced in some special sense by their local financial institutions. Yet, this position relies upon two interrelated assumptions about the character and desires of communities and financial institutions, both of which are erroneous when pushed to the point that the communitarian position advocates.

Disinvestment first presumes that all, or at least a substantial majority of, communities of depositors desire to receive from their investments returns related to goals other than profit maximization and safety. Assume that a financial institution located in community $X$ has a choice between two investment opportunities, one a loan to an individual $X$ in community $X$ and one a loan to an individual $Y$ in community $Y$. The choice between investment opportunities would hinge on which investment would bring the institution and its investors the highest yield, given considerations of risk. Therefore, absent intervention in the institution's decision, the institution would make the loan in $X$ when that loan is more profitable than one in $Y$.

29212 U.S.C. $\$ 2901$ (a)(3) (1988); see also supra note 32 and accompanying text (discussing the congressional findings memorialized in the CRA, particularly the requirement that regulated institutions meet the "convenience" and "needs" of their communities).

${ }^{293}$ Nonetheless, a congressional intent to check "disinvestment" through the CRA is substantially debatable given the rejection of the concept of PSSA prior to enactment of the CRA. See supra text accompanying note 115 . 
The disinvestment justification for the CRA would posit that the institution's initial decision for some reason should be affected by the fact that the institution is geographically situated in community $X$. In other words, the institution should make the loan to $X$ even if a loan to community $Y$ might be more profitable, given considerations of risk. Most frequently, the institution's alleged obligation is grounded in the claim that the institution receives its deposits from investors in community $X$ rather than from other communities: hence the terms disinvestment and reinvestment. This assertion relies upon two assumptions: first, that the institution in fact receives its deposits from community $X$ and, second, that those investors from community $X$ would prefer the community investment irrespective of profit and risk. Whether institutional deposit bases have remained predominantly local, a precondition to the occurrence of "disinvestment," is a debatable point. ${ }^{29}$ Even assuming that the institution receives its funds for investment from its local community, the disinvestment rationale for intervention fails for another reason. It relies upon an inexplicable proposition that, if a loan to community $Y$ would be better than one to community $X$, depositors in community $X$ nonetheless would prefer a lower yielding or less secure investment in community $X$ rather than the more profitable or safer one elsewhere. Yet, whether local communities would prefer the less profitable or riskier investment remains debatable. ${ }^{295}$ There is no evidence that investors from any specific community wish to sacrifice the profit or security from

${ }^{29}$ Intuitively, the assumption of a local deposit base seems accurate, given the local service area of many depository institutions. See supra text accompanying notes 278-83 (discussing the extent to which banks have retained important roles in their local service areas). Little empirical work has been done to address this point. However, a 1992 report by the Association of Community Organizations for Reform Now ("ACORN") that utilized publicly available deposit information did seek to tie institutions' deposit bases to their lending patterns. See ACORN, TAKE THE MONEY AND RUN: THE SIPHONING OF DEPOSITS FROM MINORITY NEIGHBORHOODS IN 14 CITIES (1992) [hereinafter ACORN STUDY], reprinted in 2 SENATE PRINT, supra note 5, at 159. The ACORN Study concluded that only four cents of every dollar on deposit in predominantly minority neighborhoods were "reinvested" in those communities, while in predominantly white neighborhoods, nearly eight cents of every dollar on deposit were reinvested. See id. at 160 . As with other similar studies, however, the ACORN Study did not correlate amounts on deposit in neighborhood institutions with the residence of the depositor. See id. at 167. Thus, whether the deposits actually came from residents within the specific community is a matter of conjecture.

${ }_{295}$ See Macey \& Miller, supra note 27, at 309-10 ("[I]t is difficult to see why communities in general suffer a net harm when funds are transferred between them (..." ). 
their investment to subsidize reinvestment in their own community. ${ }^{296}$ Yet, that is what the reinvestment view of the CRA at its extreme would dictate.

In addition to speculating erroneously that communities of depositors as a general matter desire their deposits to be placed in investments other than those that are the most profitable or secure, the reinvestment position assumes also that the financial institutions regulated under the CRA should themselves seek objectives other than to maximize their own economic advantage. Under this view of financial institutions, institutions should make lending decisions on grounds other than credit risk, ${ }^{297}$ such as perhaps an altruistic desire to "support" their community. Even if certain depositors do have a desire to see their funds put to use in the community-an "altruistic community"-it is inexplicable to transform the entire financial services industry through the CRA to accommodate those particular depositors.

A recent communitarian perspective on the CRA attempted to transcend the limitations of the communitarian reinvestment position by creating a new paradigm for financial institution regulation based upon "community empowerment." 298 Under this view, the underlying focus for financial institution-related policy and government initiatives, as well as the context by which the CRA is to be understood and reformed, would be whether local communities are empowered. ${ }^{299}$ From this general principle, the communi-

${ }^{296}$ This is not as individualist and anticommunity as it initially may sound, for particular groups of people may have a desire for income over growth, depending upon their particular needs. For example, the elderly often might prefer income over growth. Similarly, a geographic area may value the higher income over modest infrastructure improvement.

${ }^{297}$ Cf. Taibi, Community Economic Empowerment, supra note 30, at 1479 (deeming the assessment of credit risk or creditworthiness "a cultural, meritocratic 'thing"). Taibi grossly misconstrues the concept of credit risk, incorrectly rejecting the possibility of consensus on any neutral, objective standards of credit risk and therefore improperly reducing the whole of the business of banking to gut-level intuitions leading to a handshake and a character loan. See id. at 1514. Clearly consensus can be reached as to some objective standards. For example, an individual whose monthly income is less than the amount required to service the debt is a poor credit risk. While cultural factors can and do bear, often invidiously, on what constitutes "income," certainly the underlying objective "creditworthiness" test is conceptually sound.

${ }^{298}$ See id. at 1541 (advocating paradigm shift).

299 The specifics of the "community empowerment" paradigm are intentionally left vague. See id. One specific articulation of the proper regulatory approach would be the following government statement to local communities: Here are the tools, go do it yourself. See id. at 1543. 
tarian agenda would seek to protect local communities from disinvestment and encourage investment in local communities, ${ }^{300}$ to establish local control of financial institutions, ${ }^{301}$ and to resist the nationalization, if not globalization, of the financial services industry. ${ }^{302}$

By focusing on community economic needs rather than on reinvestment of community deposits, the empowerment position superficially seems to evade the conceptual limitations of the notion of "reinvestment." Yet, the funds which are to be used to "empow-

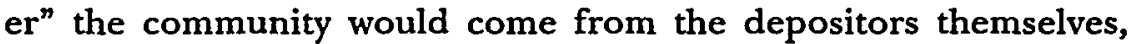
presumably members of the community. It is difficult to see how the arguments undercutting the reinvestment position do not equally apply to the community empowerment perspective. In essence, the empowerment model would allow the local community to extract profits from its own individual members. Whether, as a matter of regulatory policy, the community commonweal should universally prevail over individual member interests is questionable. Even if one accepts the proposition that individuals are constructed at least to some degree through their communal associations, the proposition that the local community good always should supervene over individual interests whenever the two collide in lending or investment decisions is inexplicable, if not an alarming challenge to personal autonomy and dignity. Reversion to vague ideological rhetoric about "empowering communities," without more, scarcely can allay such concerns.

It is therefore a highly debatable move to view the Act, in spite of its name, as reflecting an underlying ideal of community empowerment, community development, or community reinvestment. Its failure to bring about that ideal should not be seen as a failure in the Act or its enforcement. ${ }^{303}$ Perhaps as a reflection of

${ }^{900}$ See id. at 1466-68 (suggesting that community "investment" and "disinvestment" are normatively relevant).

${ }^{301}$ See id. at 1469 (advocating creation and reinforcement of "financial institutions that are community specific in their control, whether in the form of a broad-based community organization or simply a local business elite focused on profits but informed by a sense of its cultural roots").

${ }^{302}$ See id. at $1517-20$.

${ }^{\text {sos }}$ See id. at 1511-14 (criticizing the narrowness of CRA vision). Indeed, communitarian proposals for modifications of the CRA reveal the inconsistencies of the community empowerment model of the CRA. For example, Tony Taibi argues in favor of "a determinate requirement that institutions invest a set portion of their funds in approved investments." Id. at 1504, 1507-09. Because the CRA covers both large, nationally based institutions as well as small, local institutions, such an 
the shortcomings of the communitarian position, the CRA in the past did little to validate it. Even assuming that depositors in the hypothetical community $X$ should in fact prefer investment in their own community regardless of wealth maximization or safety, whether for altruistic reasons or because of a desire to subsidize development in community $X$, the CRA enforcement regime (prior to the most recent revisions) fell far short of accommodating that preference. The CRA clearly was not intended to allocate credit by requiring the institution to make the loan to community $X$ when substantially more profitable investments exist elsewhere. ${ }^{304}$ It is therefore not surprising that loans made under the original CRA regime have been found to be as profitable as non-CRA loans, if not more profitable. ${ }^{305}$

The initiative to modify CRA enforcement from its original effort-based focus toward one focusing on actual lending threatens to take the CRA closer to the extreme communitarian position, which itself relies upon a mistaken articulation of community desires and institutional structure. Basing an institution's rating at least presumptively on actual loans made provides a great incentive for institutions to make community loans for the sake of community, rather than on the basis of safe and sound banking principles. The express emphasis on community development loans, investments, and services also hints at a regulatory move toward the communitarian position. At the same time, consumer lending has been given short shrift, at least when compared to community development types of lending. Yet, the picture that the community rights position on the CRA paints of all communities being interested in community development lending rather than profit and risk is erroneous.

approach threatens smaller institutions, the precise institutions the modifications wish to protect. Yet, Taibi gives only brief mention to possible exemptions from the mandatory investment requirement. See id. at 1508 (suggesting in passing that "small independent community banks" might receive an exemption). At the same time, it is hard to conceive that federal regulatory definition of "approved community investments" for the entire country will either result in reduced bureaucracy or the community empowerment end to which Taibi's vision of the financial services industry points.

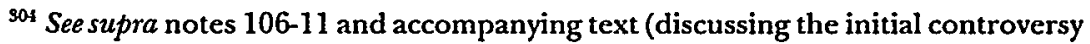
over whether the CRA would lead to credit allocation and the vociferous congressional refutation of such fears).

${ }^{305}$ See supra note 51 (discussing recent evidence indicating that CRA loans are not only "safe" but even profitable). 
Altruistic communities of depositors do in fact exist. At the same time, financial institutions do not rigidly order their sense of moral obligations toward community solely on the basis of a balance sheet. The risk posed by moving the CRA toward results, if enforced in the name of community rights, is that the community model will be imposed with broad strokes upon depositors, communities, and institutions who do not wish to see local investment occurring at the expense of profit or safety. While altruistic investors need to be linked to altruistic institutions, ${ }^{306}$ transforming the entire financial services industry to accommodate those preferences denies other communities, individuals, and institutions the ability to pursue their own desires. In sum, primary reliance upon a strong notion ${ }^{307}$ of "community" to critique or justify the CRA or to develop a model for CRA enforcement is misplaced. The communitarian position begins with the tenuous premise that the institution is investing the community's funds, and mistakenly considers all depositors to be primarily altruistic, desiring reinvestment over profit or safety. At the same time, financial institutions are required to play a role which they simply are functionally unable to play and which also acts to the detriment of many communities. To the extent that the new CRA enforcement regime is interpreted to move us closer to "community," it is a wrong step, in the wrong direction.

\section{Equality}

The flawed dialectic of antilocalism and community that has driven the CRA to date has not only served to hinder significantly any meaningful maturation of the Act but also to mask the sense of equality that surrounded its enactment. Regard for equality can be

${ }^{506}$ See infra part IV.C (discussing the role of community development corporations and community development financial institutions in promoting altruistic investment in local communities).

${ }^{307}$ A softer communitarian argument in favor of the CRA might provide that, if all things otherwise are exactly equal between investments in community $X$ and community $Y$, the institution's own community should have a superior claim for investment. This softer approach would avoid the problem that the more aggressive communitarian position invokes in advocating community investment largely irrespective of yield or risk. In addition, soft communitarianism renders the institution's safety and soundness a less relevant concern. Thus, under this view a community consciousness to lending is manifested at little cost to the financial institution. In reality, though, it is hard to imagine conditions under which investment opportunities could attain such identity as to warrant this decision between $X$ and $Y$. 
seen, albeit only subtly, in the references to the practice of redlining in the legislative history of the CRA. ${ }^{308}$ Recent data that reveal significantly disparate lending patterns based upon race ${ }^{309}$ (regardless of how rational the practice that those patterns reflect may be) have begun to clarify the connection between equality and the law of financial institutions.

Is credit a significant enough resource that we should care in any meaningful sense about inequalities involving the provision of credit? As the principal suppliers of credit to consumers and smaller businesses, local depository institutions play an important social, as well as economic, role. Affordable access to those financial services has dramatic ramifications for the quality of lives. The example of the home mortgage finance industry illustrates the intersection of the economic and social dimensions of banking. Private home ownership in our society largely is attained through incurrence of debt. ${ }^{310}$ An individual may desire the opportunity to conduct her life in a private home because she values the freedoms associated with private home ownership in our society. ${ }^{311}$ Assume that persons $X$ and $Y$ prefer to reside in privately owned homes. If $X$ is granted the opportunity ( $X$ obtains mortgage financing) to acquire the home and $Y$ is not ( $Y$ does not obtain mortgage financing), $X$ has been given the desired benefits of home ownership while $Y$ has been denied.

While the role of banks and other traditionally local lending institutions in facilitating individual home ownership provides the most salient example of this social dimension of banking, access to other financial products traditionally provided by those institutions has a profound effect on the ability of individuals and firms to conduct their personal or business lives, as the case may be. For example, low-income consumers' access to payment services, through a checking account or otherwise, recently has become a matter of concern. ${ }^{312}$ To the extent that we exclude individuals

${ }^{303}$ See supra notes 92-105 and accompanying text (discussing the role of antiredlining theory, and divestment in general, in the development of the CRA).

${ }^{309}$ See supra note 80 and accompanying text.

${ }^{310}$ Generally, the high cost of real estate makes acquisition financing essential to its purchase. Even if the buyer of a home has sufficient liquid capital to purchase the home outright, the tax benefits of home mortgage loans, as well as the lost opportunity costs of investing the funds elsewhere, make debt acquisition highly attractive.

311 See generally Jeremy Waldron, Homelessness and the Issue of Freedom, 39 UCLA L. REV. 295 (1991) (examining the relationship between homelessness, freedom, and the rules of private and public property).

${ }^{312}$ See generally Edward L. Rubin, The Lifeline Banking Controversy: Putting 
from the payment system either through lack of access to a provider of payment services or access only at unaffordable cost or unacceptable risk, ${ }^{313}$ it becomes an issue of social equity. Similarly, the cost at which small businesses are able to obtain access to credit products directly affects those businesses' abilities to compete and to expand.

The point is not that credit and other financial products are as essential for survival as food and shelter. We have been transformed culturally, though, to accept a general ethic of debt. Accordingly, the ability of borrowers, whether individual consumers or firms, to obtain credit and other financial services and products does have a moral dimension. Access to capital allows borrowers to exploit their assets and facilitates transformation of individual desires into concrete reality-a house, an education, a business, a livelihood. Denial of any one of these ultimate objects, itself, on other than warranted grounds, is certainly cause for a clamor. Therefore, denial of the conventional means to acquire the same object-credit-should raise equally vociferous objections. ${ }^{314}$

Deregulation to Work for the Low-Income Consumer, 67 IND. L.J. 213 (1992) (arguing that lifeline banking proposals can be strengthened and made more accessible to lowincome consumers by deregulating the financial services industry).

\$13 The real problem is not one of exclusion from the payment system, but rather one of cost and safety. When traditional depository institutions withdraw from areas, other enterprises jump in to serve the demand for payment services. However, some evidence suggests that these substitutes are both more expensive and riskier:

A basic bank account costs less than cashing two paychecks a month and buying five money orders to pay bills. Check cashing businesses also do not provide a safe place to keep money, opportunities to earn interest, or access to credit. Further, money order vendors that do business with check cashing establishments are not insured or protected as banks are. Last year [1991], two L.A. money order companies went bankrupt and as a result the money orders that low-income people had purchased with cash to pay rent and utility bills simply bounced.

1992 Senate Hearings, supra note 1, at 115 (testimony of Gilda Haas, Communities for Accountable Reinvestment).

Access to payment services appears to track wealth and race. Fewer lowerincome and minority families maintain checking accounts than higher-income and white families. Preliminary data indicate that in 1992 an average of $87.5 \%$ of families had some sort of transaction account, in contrast to only $63.7 \%$ of families with incomes lower than $\$ 10,000$ per year. See Kennickell \& Starr-McCluer, supra note 280 , at 869 tbl. 5. Similarly, although $93.1 \%$ of white families maintained a transaction account, only $67.5 \%$ of nonwhite and Hispanic families did. See id. The data from 1992 indicate that the percentage of nonwhite, low-income families that have a transaction account has increased slightly from 1989. See id. at 868-69 tbl. 5.

${ }^{314}$ Cf. McCaffery, supra note 288, at 649 ("Where individuals are blocked by market failures from pursuing their life plans, efficiency talk loses much of its 
If equality matters in the provision of credit (and it does and should), legislatively reconciling the aims of equality with the institutional function of financial institutions is a difficult task. One need not venture far into political philosophy and constitutional theory to discover that the meaning of "equality" and intervention on the basis of equality is widely debated. ${ }^{315}$ Moved into the more concrete arena of financial institution regulation, the more precise issue might be posed as one of differential treatment of individuals by institutions whose very existence is based upon the ability to differentiate-or discriminate-between good borrowers and bad borrowers. Legislative intervention in the name of equality that too heavily intercedes with this differentiating role of institutions in the granting of credit threatens the essential economic nature of those institutions. It is precisely this economic function that must be exercised to distribute capital and financial services to all who need them. Equality and the differentiating role of financial institutions therefore are inherently always in tension. Excessive intervention into otherwise private credit decisions in the name of equality may ultimately weaken the form of institution that provides credit and, with it, the ability of borrowers to obtain credit. Failure to intervene in the face of disparate treatment, though, risks contravening our social commitment to the principle of equality.

This uneasy alliance between preserving the institutional providers of credit and ensuring equality provides an underlying guide for assessing proposals for regulating bank lending decisions. It particularly illuminates the improvidence of a broad, redistributive model for intervening into the affairs of banks and other financial institutions. Those institutions are designed to exploit the inequalities between potential borrowers, and their economic existence is predicated upon making decisions based upon assessing the relative risk of any borrower. Intervention that aggressively pursues redistributive goals irrespective of any concomitant efficiency losses is perilous. Accomplishing a wholesale redistribution of resources through financial institution regulation ultimately can come only through transforming financial institutions from

normative appeal.").

${ }^{315}$ See, e.g., ROBERT NOZICK, ANARCHY, STATE, AND UTOPIA (1974); JOHN RAWLS, A THEORY OF JUSTICE (1971); AMARTYA SEN, INEQUALITY REEXAMINED (1992); see also Richard A. EPSTEIN, Forbidden Grounds: THE CASE AGainst EMPLOYMENT DISCRIMINATION LAWS (1992) (discussing equality in the context of antidiscrimination laws). 
assessors of risk to conduits for redistribution. Yet, it is the ability of these institutions to assess risk that makes them socially and economically valuable. Even if a wholesale redistribution of resources in the name of equality were viewed as warranted as a general social matter, designating the financial institutions that provide credit to bear the costs of such a result conflicts directly with the very reason why we want these institutions to exist, resulting in great social cost to all.

Although ensuring equality in credit through legislative intervention into a bank's decision should not mean in any strong sense that $X$ and $Y$, above, have an equal right to receive credit from any particular institution, some might argue at the other extreme against intervention entirely. Under this view, the market would provide the best solution to the documented problems of rational or irrational credit discrimination. ${ }^{316}$ Whether redistribution should be through other means would be an issue wholly separate from the anti-intervention stance on financial institutions law. Yet a full commitment to the moral importance of credit and the ability of persons and firms to compete freely in the market for credit make it hard to stand for such an extreme market-based position, ${ }^{317}$ particularly if a modest intervention that satisfactorily balances the institutional function of credit-providers with the social goal of equal treatment can be found.

That more modest position between the extremes of aggressive redistribution and anti-intervention does exist. The dimension of social equality intersects with the economic risk assessment function of financial institutions at two general points. First, the economic function of financial intermediation creates the need for equality of access to the services provided. Once a niche in the provision of financial services has been developed, inequalities that merit intervention may emerge if access to financial intermediaries is barred or made more costly. Barring potential borrowers' access to a commercial bank's expertise in valuing assets, for example, renders those borrowers unable to liquidate those assets in an

${ }^{316}$ See McCaffery, supra note 288, at 635 (describing the anti-interventionist position on employment discrimination laws as the view that "markets are apt to work their way to a better answer, even in the presence of market failures, than government intervention can provide"); Swire, supra note 81 (describing economists' views on the market).

${ }^{317}$ Cf. McCaffery, supra note 288, at 654 ("No normatively powerful concept of efficiency should compel society to accept the distortions wrought by decades, even centuries, of discrimination."). 
economically advantageous manner. Access only at higher cost or risk raises the costs incurred in capitalizing on the value of those assets. Ensuring equality of access at this very basic conceptual level does not conflict with the economic function of the institution in the strong manner that the broad redistributive argument, above, does. ${ }^{318}$

The second point at which equality and the differentiating function of financial institutions can coexist is with respect to equality of opportunity. In this area, though, the economic function of financial intermediaries threatens to conflict with the need for equality of opportunity. Even when equality of access exists, the economic function of financial intermediaries dictates broad discretion for institutions in pricing financial services and in setting the conditions under which those services are to be provided. As discussed above, commercial banks have developed an expertise in assessing the credit risk of potential borrowers due to their skill in valuing assets or other means of assessing the default risk associated with a particular loan. ${ }^{319}$ Legal intervention into this area of expertise particularly threatens the differentiating and risk assessment role of institutions. Yet, failure to intervene when the evaluative techniques are inconsistently applied to particular borrowers or classes of borrowers permits equally troubling differential treatment of borrowers.

Ensuring equality of opportunity therefore risks a conflict with an essential function-discrimination-of lending institutions. As an example of the uneasy coexistence of equality of opportunity and the function of financial institutions in providing credit, reconsider the instance of $X$ and $Y$ applying for a home acquisition mortgage at the same financial institution, with $X$ 's application being approved and $Y$ 's being denied. As an initial matter, a generic inequality of opportunity exists $-X$ has the opportunity to purchase a home and $Y$ does not, absent independent means of purchasing the property or a successful loan application elsewhere. The more problematic question is what equality of opportunity should require with regard to intervention in this differential treatment.

${ }^{318}$ The costs born by institutions in ensuring equal access, however, are indeed relevant. See infra part III.A.1-2. (discussing the search costs involved in disseminating information within the institution's community and identifying potentially good investments therein).

${ }^{319}$ See supra text accompanying notes $259-68$ (discussing the traditional conception of banks as intermediaries in the provision of credit, through their role as assessors of credit risk). 
Disparity between these two individuals in mortgage treatment may arise for a myriad of reasons. First, $X$ may simply have easy geographic access to a source for mortgage finance and $Y$ either does not or only does at a high cost. ${ }^{320} X$ 's purchase, given $X$ 's financial position, credit history, and collateral may constitute a better credit risk than $Y$ 's. If $X$ and $Y$ are in an unequal financial position or have offered different collateral, the economic nature of lending dictates that an institution have broad discretion in evaluating the loan application. If $X$ has sufficient income to service the debt and $Y$ does not, ${ }^{321}$ intervention into the bank's decision to approve $X$ 's loan application and to deny $Y$ 's-in effect overruling the independent credit assessment of the institution-intrudes into the institution's ability to assess credit risk. A similar intrusion occurs if the bank's decision was based upon a determination that $X$ 's collateral created a less risky investment for its depositors. Excessive intervention into the bank's discretion in determining which borrowers constitute good investments and which constitute bad investments would overrule the institution's expertise in assessing investments and in diversifying its portfolio to maximize the returns to its investors within an acceptable level of risk. Regulatory limitations in pursuit of equality of opportunity that either preclude institutions from making investments that they would otherwise make, or compel institutions to make investments that they otherwise would not make, hazard diminished returns to investors and, consequently, undermine the competitive position of financial institutions. In this regard, equality of access may be undermined when equality of opportunity is pursued too aggressively.

In some cases inequalities may result from differential treatment of $X$ and $Y$ not based on legitimate factors of credit risk. The ECOA's imposition of the antidiscrimination norm ${ }^{322}$ into credit

${ }^{320}$ For example, $X$ may live in a community that has a number of easily accessible bank branches that engage in mortgage loan origination, whereas $Y$ may have to travel to another area to apply for a loan and incur the cost of investigating the unfamiliar mortgage lender.

${ }^{321}$ Financial institutions use a statistical practice of credit scoring in assessing whether or not to grant a loan. See generally CREDIT SCORING AND CREDIT CONTROL (L.L. Thomas et al. eds., 1992) [hereinafter CREDIT SCORING]. While income sufficient to service the debt is predictive of good credit, other predictive variables include employment status and category, past delinquencies, and years at present address. See J.N. Crook et al., A Comparison of Discriminators Under Alternative Definitions of Credit Default, in CREDIT SCORING, supra, at 203, 218 tbl. 1.

${ }^{322}$ See supra note 76 (discussing the ECOA's provisions against discrimination in lending). 
decisions is the most obvious reflection of our commitment to the principle of equality of opportunity as it applies to credit decisions. The imposition of the antidiscrimination norm through the CRA, however, has generated much objection. ${ }^{323}$ While not denying that discrimination in lending is an issue of tremendous social implications, these critics argue either that Congress did not intend the CRA to be an antidiscrimination statute, ${ }^{324}$ or that what is needed is stronger enforcement of the ECOA to ensure equality of opportunity (rather than incorporation of equality of opportunity within the CRA). ${ }^{325}$

The attention in the CRA debates and hearings to the problem of redlining-which can be related to irrational, discriminatory practices-makes it plain that Congress was aware of the interrelationship between the CRA, credit needs, and discrimination. ${ }^{326}$ The absence of an express antidiscrimination intent for the CRA therefore is not as problematic as these critics would assert and is consistent with the legislative history of the Act. ${ }^{327}$

${ }^{323}$ See, e.g., Macey \& Miller, supra note 27, at 298-99 (finding no indication in the legislative history of the CRA that Congress intended to mandate a general prohibition on discrimination in lending); id. at 337-40 (criticizing enforcement of the antidiscrimination norm); White, supra note 28, at 290 (arguing that the antidiscrimination norm is not justifiably part of the CRA, but rather is part of the ECOA).

${ }^{324}$ See Macey \& Miller, supra note 27 , at 299 \& n.20 (arguing that the CRA was intended to shape lending patterns to benefit communities, rather than to remedy racial, ethnic, or gender discrimination).

${ }^{325}$ See White, supra note 28, at 290 (arguing that discrimination in lending would be better handled by vigorous enforcement of the ECOA rather than by less direct regulatory methods offered by the CRA).

${ }^{326}$ See supra text accompanying notes $92-105$ (discussing evidence that the CRA was initially aimed at both redlining and disinvestment).

${ }^{327}$ Macey and Miller state, "[a]s the title of the statute indicates, the focus of the legislation was on the problem of depository institutions shipping funds outside the areas in which the funds were obtained." Macey \& Miller, supra note 27, at 299. The authors conclude from this language (and from other legislative history that is equally unpersuasive) that there is no persuasive indication in the legislative history that Congress intended to combat discrimination. See id.

This author does not find the absence of an antidiscrimination norm in the title of the CRA troubling from a perspective of legislative intent. Selection of a rhetorically appealing name that has little to do with the substance of the legislation is a time-honored legislative tradition. See, e.g., Rubin, supra note 247, at 247 (naming Truth-in-Lending "a public relations masterstroke"); $i d$. at 283-84 (deriding invocation of "Truth" as a goal of Truth-in-Lending Act). In addition, the statement in the Act that institutions have an obligation to meet community credit needs has sufficient textual flexibility to admit virtually any underlying justification for that obligation. It is questionable, given the rejection of the PSSA, that any strong disinvestment rationale survived enactment. See supra text accompanying notes 102-16 (discussing 
The second objection to incorporating an antidiscrimination intent into the CRA is that the ECOA alone should be sufficient to redress problems of credit discrimination. The ECOA, however, has proven to be an extremely ineffective means of ameliorating discrimination in credit decisions. ${ }^{328}$ Even assuming that more vigorous enforcement of the ECOA has begun, its prohibitory mechanism in policing discrimination comes up short as a complete solution to the problems of access and opportunity. Given the subtlety with which most discrimination in lending now occurs, "examiners can be expected to uncover only the most flagrant abuses. ${ }^{\text {329 }}$ Hence, reliance upon the ECOA's prohibitions as the cure to the problem of equality of opportunity in lending is misplaced. Moreover, the ECOA fails to address the problem of equality of access in any significant respect. Even if opportunity were to be ensured through the ECOA-and the statute's efficacy in providing such insurance is dubious-access remains unaddressed by the ECOA. Something more is needed to ensure equality of opportunity and equality of access, and that should be the CRA.

A commitment to equality and the subsidiary principles of access and opportunity provide the best justification for the CRA's intervention into a financial institution's decision to grant credit. These principles are reflected in the ECOA and, unlike community or localism, provide the most defensible construction of the largely ambiguous legislative history of the CRA. Accordingly, the fashionable debate over localism versus community, which has served only to stifle the CRA to date, should be rejected and the CRA reconstructed as a proper (at least initially) and justified legislative attempt to secure equality of access and opportunity. The question then arises of how the CRA should be implemented and enforced to meet the demands of equality of access and opportunity.

the proposal for PSSA and its ultimate rejection). Although the original Act did not initially mention race and gender, subsequent amendments to the Act expressly mention race and gender as factors meriting CRA consideration. See supra text accompanying notes $42-46$ (discussing the 1991 and 1992 amendments).

${ }^{328}$ See supra note 78 and accompanying text (discussing criticisms and studies of the effectiveness of the ECOA).

${ }^{329}$ MUNNELL ET AL., supra note 81 , at 4 . 


\section{ASSESSING THE CRA}

As discussed in the previous section, the CRA is best viewed as an antidiscrimination statute evidencing an intent to ensure equality of access and equality of opportunity in the granting of credit. Yet, those bare principles provide little guidance for properly constructing a CRA that accommodates that end. This Part will first address the scope of the principle of equality of access and the means by which the old and new enforcement schemes accommodate, or fail to accommodate, that principle. A discussion of how the CRA should further equality of opportunity follows. Finally, the enforcement role of consumer groups under the CRA will be addressed.

\section{A. Access}

Any meaningful construction of the principle of equality of access should begin with ensuring individuals geographic access to financial institutions. Yet, "access" also has a more subtle connotation based not solely upon geographic access, but also upon access to information about the financial institution and the services and products that it provides. Geographic access and informational access will be discussed in turn.

\section{Geographic Access}

Geographic access to financial institutions should simply be a result of demand. If profitable investments could be made in any particular area, then geographic access ipso facto is served..$^{330}$ Conversely, when that area does not present profitable investment opportunities, creating access is superfluous, not to mention costly. Under this view, regulation that requires institutions to provide access countermands the natural operation of the market and, therefore, is unwarranted. Intervention to remedy the economic marginalization of geographic areas also would be rejected: the area as a whole either provides no profitable investment opportunities (compared to others available), or the costs of identifying potentially good investments within the area are so high as to render any

${ }^{330}$ See, e.g., Macey \& Miller, supra note 27, at 308-09 (questioning why local institutions are not exploiting local investment opportunities "if there are good profit opportunities available locally and readily identifiable at low cost"); Swire, supra note 81 (discussing economic views on incentives for exploiting profit opportunities). 
investment there undesirable. Accordingly, the CRA-either by mandating loans in otherwise less profitable ventures or by requiring institutions to incur search costs for investments that they otherwise would not make-unjustifiably interferes with the market in creating access.

Yet, once again, this argument assumes a market for credit far out of touch with historical reality. That CRA loans (at least until now) have proven to be as creditworthy and profitable as non-CRA loans ${ }^{331}$ undermines the claims that demand adequately would be met absent intervention and the claim that the CRA (at least as originally enforced) required an institution to make less-profitable investments than it otherwise would have made. The successes of the CRA provide evidence that at least some institutions were in fact failing to address demand in their own neighborhoods. Ensuring geographic access to financial service providers therefore raises the issue of to what extent, and how, the CRA should be structured to encourage institutions to serve areas in which access is limited.

Under the initial regulatory enforcement regime, the CRA in fact required institutions to incur search costs that they otherwise would not have expended, absent intervention. ${ }^{332}$ Yet, that regime did not require institutions to make investments that they otherwise would not have made in the exercise of business judgment. These enforcement efforts did not compromise-and in fact they respected-the institutional function of financial institutions while facilitating access at largely nominal cost. ${ }^{333}$

Instead of focusing on how to reduce the costs of facilitating access to credit, the new enforcement scheme shifts from measuring access by efforts to measuring access by results in actual lending. ${ }^{334}$ The Lending Test, which measures certain loans actually made and which is given the greatest weight in an institution's overall CRA rating, ${ }^{335}$ as well as the Service Test ${ }^{336}$ appear to be attempts to measure how well an institution creates geographic access. The

s31 See supra note 51 (discussing evidence of the performance of CRA loans).

332 See Gruben et al., supra note 26, at 36 (recognizing search costs imposed on lending institutions by the CRA).

${ }^{333}$ See supra note 177 (citing evidence that the old CRA enforcement regime required relatively minimal costs of compliance).

${ }^{334}$ See supra part I.B.2.a (explaining how recently proposed revisions to the CRA regulations seek to evaluate financial institutions based on actual results in meeting community credit needs rather than on effort expended).

${ }^{335}$ See supra text accompanying notes 185-94, 206-07 (discussing the Lending Test and its role in an institution's overall CRA rating).

${ }^{336}$ See supra text accompanying notes $199-205$ (discussing the Service Test). 
results of access being provided admittedly are a more reliable indicator of access than are data on efforts. Money out the door surely means that there is access to credit. Yet, a results test is still an ill-tailored indicator of the existence of actual access. Consider the example of a low- and moderate-income geography that is presently served by a small institution and a branch of a larger institution. If demand is being met in the area, under the Lending Test, the larger institution has the incentive to co-opt a share of loans from the smaller institution. ${ }^{337}$ Yet, access in fact was not a problem in that particular geography. Results therefore can be a meaningless, and overbroad, predictor of unmet demand.

If demand is not being met in the geography, it is hard to see how measuring access through efforts is less satisfactory than using results. The efforts-based standard led to actual results that were consistent with safe and sound lending principles. ${ }^{338}$ At the same time, unmet demand can adequately be accommodated within any efforts-based evaluation process. In addition to being an ill-tailored monitor of demand, results may turn out to be more costly to monitor, should the new regime lead to higher reporting and enforcement costs. Moreover, emphasis on results gives institutions an incentive either to abandon the criteria of safety and soundness for the sake of a loan made, or to gerrymander assessment areas to ensure adequate results.

True, regulators have indicated that problems of demand will be factored into the results-based test. ${ }^{339}$ Presumably, therefore, an institution will not be required to "buy" results from other institutions or to make unsafe loans for the sake of community investment. Yet, with respect to geographic access, what might be deemed a shifting of presumptions from efforts to results is a dangerous move. The focus on efforts provided a reliable indicator of access at what might be shown to be less cost than results, while avoiding the overbreadth and expenses of the results-based test.

937 This incentive to "buy" CRA loans from other institutions has the curious, and presumably unintended, effect of forcing smaller institutions into a competitively disadvantageous position vis-à-vis larger institutions that wish to obtain a greater number of loans for CRA evaluation purposes. See Claudia Cummins, Bankers Attack CRA Plan as Unfaiv and Unworkable, AM. BANKer, Feb. 3, 1994, at 1, 3 (noting the predatory effect of the December 1993 proposed Lending Test).

${ }^{338}$ See supra note 51 (discussing recent data showing that CRA loans under the efforts-based regime were frequently as safe or safer than conventional loans).

${ }^{339}$ See Final Regulations, supra note 181 (to be codified at 12 C.F.R. $\$ 228.21(b)$ ) (stating the context in which the Federal Reserve Board should apply the proposed tests and standards). 
One compelling argument raised against the CRA is that it compels institutions to refrain from entry into communities that have limited access to financial institutions. ${ }^{340}$ According to this argument, the CRA therefore contravenes its purpose to increase access. Much of this point is overstated. First, the institution's record of opening and closing branches was, and still is, proposed to be part of the CRA evaluation process. ${ }^{341}$ Accordingly, any flight from, or reluctance to enter, underserved communities will have negative effects on the institution's CRA rating and any expansion plans that the institution may have in the future.

In addition to regulating bank entry into and exit from underserved areas, the CRA, properly interpreted, acts subtly to encourage branching in those areas. Branching in an area is a highly effective means of acquiring information about potential investments in that area. ${ }^{342}$ Branching, therefore, might in some instances be a way for the institution to reduce the CRA information tax. Assume that an institution's service area includes neighborhood $Y$. Under the old enforcement regime, the costs of searching for information about creditworthy borrowers in neighborhood $Y$ in effect was imposed upon the institution. Under the new regime, the goal of making loans without compromising safety and soundness provides an incentive to acquire information about potential borrowers in the area. If the costs of establishing a branch in the neighborhood are less than the costs of independently searching for information about potential borrowers in that neighborhood, the institution would have an incentive to establish the branch, and so viewed, the CRA actually encourages bank branches in underserved areas.

Similarly, the Act discourages bank exit because exit is advisable only when the costs of maintaining the branch to perform the neighborhood's search function exceed the costs of conducting the search absent a branch. Even if an institution were in fact to close a branch, if the institution's service area still includes the area in which the branch was located, the effort required by the CRA in acquiring information about the neighborhood still exists. Accord-

${ }^{340}$ See Macey \& Miller, supra note 27 , at 314-15, 340-41 (arguing that the CRA impedes entry into underserved communities).

${ }^{341}$ See supra note 135 (discussing the assessment factors used to determine an institution's CRA rating); supra note 203 (discussing the importance of an institution's accessibility, based upon its record of opening and closing branches).

${ }^{342}$ See, e.g., Gruben et al., supra note 26 , at 29 (discussing the informationgathering function of branches). 
ingly, even in the absence of a branch, potential borrowers in the area are assured of some access to bank services through the search efforts of the institution. ${ }^{343}$

\section{Information Access}

Under the old regime, institutions were evaluated as to their efforts to engage in dissemination of information concerning their products. ${ }^{344}$ Through these requirements, potential borrowers were informed as to products available from that institution. There may be a bank branch on every corner, but absent information concerning products available to potential customers in the area, the CRA's goals of equality of access are unmet. This is particularly so for individuals who historically have been denied access to credit. ${ }^{345}$

The recent changes to CRA enforcement constitute a shift away from ensuring informational access. Instead of focusing on how to reduce the costs of information dissemination under the CRA, the new regulations significantly abandon the information requirements of the old regime. Some informational criteria may be considered as factors under the Service Test. ${ }^{346}$ Even if the Service Test is interpreted to encompass informational services, however, the nominal weight that the Service Test carries in the overall rating ${ }^{347}$

${ }^{343}$ The entry/exit concern has its greatest validity when an institution is considering entry into an area that was previously not part of its CRA assessment area. If the new regine is interpreted to require lending, entry into the area would result in mandatory lending in that area, rendering the entry less profitable. Exit, which would result in narrowing of the institution's CRA assessment area, is less problematic because the exit would be considered in the CRA evaluation process.

${ }^{344}$ See supra notes 135 (listing the assessment factors used to determine an institution's CRA rating), 138-42 and accompanying text (discussing the CRA rating categories "ascertainment of community credit needs" and "marketing and types of credit offered and extended").

${ }^{345}$ See supra note 80 and accompanying text (noting that, despite the ECOA, evidence exists to show continued lending discrimination). A 1993 survey concerning the ability of African-American business owners to raise capital found that "being snubbed . . . is pretty much the norm." Eugene Carlson, Turned Down, WALL ST. J., Feb. 19, 1993, at RI. Lack of information on sources of capital was cited as one reason for the difficulties in raising capital. See id. at $\mathrm{R} 5$.

${ }^{346}$ See, e.g., Final Regulations, supra note 181 (to be codified at 12 C.F.R. $\S 228.12(j)$ ) (defining community development services). The December 1993 proposal more explicitly accommodated information when it allowed an upward adjustment in an institution's Service Test rating for credit support and counseling services. See December 1993 Proposed Regulations, supra note 11, at 67,490 (to be codified at 12 C.F.R. $\$ 228.9(c)(2))$.

${ }^{347}$ See supra text accompanying notes 206-07 (stating how an institution's overall 
unjustifiably deemphasizes information. The shift to results under the Lending Test also presumes that actual loans indicate adequate provision of information to potential borrowers. Yet, as with geographic access, results are an ill-tailored indicator of whether information is in fact being provided. A loan may or may not indicate successful information dissemination to borrowers.

In sum, with respect to geographic access and informational access, the new turn to a results-based CRA may prove to be excessive and unfortunate. The old efforts-based regime attempted to create access while minimizing cost to the financial institution. Results might be a reliable indicator of access to financial institutions, but they may, as enforced, turn out to be overbroad and come only at increased compliance and enforcement costs. ${ }^{348}$ The emphasis on results might also compromise safety and soundness, and might create an illusion of access where none really exists. At its best, measuring CRA performance through results may only accomplish the same end as an efforts-based regime, ultimately at higher costs.

\section{B. Opportunity}

As stated above, ensuring equality of opportunity justifies the incorporation of the antidiscrimination norm into the CRA. ${ }^{349}$ Some proposed reforms handle the antidiscrimination norm much more effectively and directly than the prior regime did (in contrast to their respective handlings of the equality of access norm proposed by this Article). The old CRA assessment factors that incorporated the antidiscrimination norm into the examination process did provide some check on discriminatory practices beyond that of the ECOA. The CRA thereby allowed a "second look" at an institution's practices that resulted in denial of equal opportunity. The problem with the old regime's approach to the antidiscrimination norm was one of relative weight. Under the old assessment factors, evidence of prohibited discrimination was weighed equally with the other factors. ${ }^{350}$ Under this approach,

CRA rating is determined).

${ }^{348}$ See supra text accompanying notes 240-44 (arguing that the new enforcement regime has these problems).

${ }_{\text {s49 }}$ See supra text accompanying notes 319-29 (arguing that one of the foundations of the CRA should be equality of opportunity).

${ }^{950}$ See supra notes 135 (stating the assessment factors used to determine an institution's CRA rating), 143 (discussing the antidiscrimination factor, in particular). 
an institution that had engaged in illegal discrimination conceivably could receive a "satisfactory" grade.

Yet, it seems clear that an institution that discriminates in the manner that the ECOA prohibits has contravened the principle of equality of opportunity, and therefore has transgressed the CRA. Perhaps in recognition of the antidiscriminatory underpinnings of the CRA, the revised enforcement regime properly attempts to move away from the original enforcement approach. Under the new regime, evidence of discrimination or other illegal practices will factor into an institution's overall GRA rating. ${ }^{351}$ The weighting of the norm thus appears to have been strengthened somewhat to enforce the antidiscrimination factor more effectively.

While this enhancement of the CRA's antidiscrimination norm is a justifiable move toward ensuring equality of opportunity, the full scope of the antidiscrimination norm and its relationship to the CRA enforcement process are more problematic issues left unresolved by regulators. Certainly a legal finding of discrimination should not be the only consideration related to credit discrimination that factors into the CRA evaluation process. Evidence of discrimination, other than a legal finding of discrimination, accordingly should bear significantly on the evaluation process. On the other hand, an institution that has been found to have engaged in illegal discrimination should merit a less than satisfactory rating, as regulators first proposed in December 1993. ${ }^{352}$ Although the

${ }^{351}$ See supra text accompanying notes $214,230,239$ (discussing antidiscrimination provisions applicable to all institutions, small institutions, and institutions' strategic plans, respectively).

${ }^{352}$ Under the December 1993 proposal, a finding of discrimination would have per se resulted in a less than satisfactory grade. See December 1993 Proposed Regulations, supra note 11 , at 67,490 (to be codified at 12 C.F.R. $\$ 228.10(\mathrm{~b})$ ). The proper burden of proof necessary to show discrimination that would have resulted in this downgrading became an issue of controversy. The December 1993 proposals suggested that the rating be downgraded only where an institution had "[e]ngaged in a pattern or practice of illegal discrinination that it has not corrected fully" or where it had "[c]ommitted an isolated act of illegal discrimination of which it has knowledge and that it has not corrected fully or is not in the process of correcting fully." Id. While this test surely encompassed disparate treatment on grounds prohibited by the ECOA, consumer activists demanded that the test include situations of disparate impact. See Association OF COMMUNITY REORGANIZATIONS FOR REFORM NOW (ACORN), ANALYSIS OF THE NEW COMMUNITY REINVESTMENT ACT (CRA) REGULATIONS 25 (Jan. 1994) (unpublished briefing paper, on file with author). The provision in the October proposal that "evidence" of discrimination would be an independent consideration that would adversely affect the institution's overall CRA rating was the resulting compromise. See 1994 Proposed Regulations, supra note 181, at 51,274 (to be codified at 12 C.F.R. $\S 228.28(\mathrm{c}))$. 
antidiscrimination norm properly seems to have been given greater emphasis in the new enforcement scheme, the reservation of substantial regulatory flexibility in determining the effect of evidence of discrimination on an institution's rating and on applications subject to the CRA is disconcerting. This is especially true given regulators' often inconsistent attitudes toward the ECOA in reviewing recent applications of institutions charged with fair lending violations. ${ }^{353}$

The relationship between equality of opportunity and the CRA has generated divergent views on the extent to which the opportunity principle should be implemented through the CRA. For example, some have suggested that the CRA does, or should be interpreted to, mandate affirmative, targeted lending programs for previously underserved borrowers. ${ }^{354}$ Even though the legislative history of the CRA is often ambiguous, one thing that is clear is Congress's intent not to implement a credit allocation system through the CRA. ${ }^{355}$ It is hard to see how requiring private lending institutions affirmatively to engage in targeted lending programs does not contravene this intent.

More fundamentally, it is difficult to reconcile targeted lending programs as a general CRA policy with equality of access and equality of opportunity. Consider a program under which an institution agrees to lend a specified total sum to low-income

${ }^{853}$ Compare Shawmut Nat'l Corp., 80 Fed. Res. Bull. 47 (1994) (denying an application, by a narrow majority, principally on the basis that the applicant was under investigation for ECOA violations) with Barnett Banks, Inc., 80 Fed. Res. Bull. 1012 (1994) and Barnett Bank of Palm Beach County, et al., 80 Fed. Res. Bull. 1033 (1994) (approving applications even though applicants were under investigation for ECOA violations). In each of the Bainetl orders, the Board cited the Justice Department's failure to provide information concerning the investigation. See 80 Fed. Res. Bull. at 1013, 1037.

${ }^{354}$ See generally Taibi, Community Economic Empowerment, supra note 30 (reviewing various economic views on the CRA). The December 1993 proposals moved toward the affirmative action concept of lending, in that the proposed Lending Test, Investment Test, and Service Test targeted for consideration the institution's market share of loans in, investments that benefited, and services to, low- and moderateincome geographies. See December 1993 Proposed Regulations, supra note 11, at 67,487-90 (to be codified at 12 C.F.R. $\$ \$ 228.7-.9$ ); see also supra note 14 (discussing the proposed market share component of the Lending Test).

${ }^{355}$ See supra text accompanying notes 106-11 (discussing the initial concerns, and congressional denial, that the CRA would lead to credit allocation). The claim that "credit allocation" contravenes the history of the CRA should not be interpreted as a rejection of credit allocation as a general policy matter. Rather, a credit allocation purpose for the CRA was specifically rejected in the debates surrounding enactment of the CRA. 
borrowers within a particular area for the purchase of housing. Even if all targeted borrowers are victims of prior lack of access to the institution and/or prior discriminatory practices by the institution, the program does little to address or remedy any existing lack of access and opportunity. ${ }^{356}$ While the targeted borrowers in effect receive redress for the practices, mandated private affirmative lending programs only serve to mask any underlying problems with access and opportunity.

This is not to say that past institutional practices and a history of social and economic marginalization that have contributed to inequalities in access to credit do not merit active government intervention, that the ECOA should not be vigorously enforced to remedy credit discrimination, or that targeted lending programs constitute questionable policy. Development of affirmative lending programs is necessary, and creative underwriting to reach underserved borrowers should be encouraged. But it is indefensible to assert that, through the CRA, private institutions should bear the risk for such programs. The turn to results therefore threatens to emerge as a bureaucrat-administered lending program that selfservingly places any losses that ultimately ensue on private institutions. Accompanying those losses is the blame for the ineffectiveness of the CRA in solving all of the problems of urban decline, community disintegration, and violence. ${ }^{357}$ These problems, however, are, at a basic level, the responsibility of government rather than the bank on the corner. While an incentive for institutions to participate meaningfully in government-sponsored lending programs and in development of lending programs in the community is crucial, ${ }^{358}$ the CRA should not be a broad-stroke mandate that certain private institutions bear the whole cost for remedying a dismal social situation that is the role, and responsibility, of government.

${ }^{556}$ Cf. McCaffery, supra note 288 , at 651 (arguing that redistribution "compensate[s] the victims of market failure without curing the market failure" and may actually "aggravate market failure").

${ }^{357}$ See supra note 25 (noting examples of expressed intent that the CRA be used to improve communities by, for example, preventing altercations like the Los Angeles riots).

${ }^{358}$ The provisions of the new regime that give consideration to innovative and flexible creative underwriting and investment strategies properly further this goal. See supra notes 191, 197 and accompanying text (discussing the requirement that institutions use innovative or flexible lending practices). 


\section{The Role of Community Groups}

A myriad of views have arisen concerning the proper role of community groups under the CRA. The current perspective assumes that community groups should enforce the Act. For example, the recent amendments to the CRA which have enhanced public disclosure of an institution's CRA performance ${ }^{359}$ operate on the principle that disclosure provides an additional enforcement mechanism for the Act. ${ }^{360}$ Community activists themselves view their role as that of enforcers rather than facilitators. ${ }^{361}$

Uncritical acceptance of consumer groups as enforcers of the CRA is problematic for several reasons. The consumer group enforcement mechanism allows groups and individuals who have little, if any, political accountability to enforce a law that substantially taxes highly regulated financial institutions. This lack of accountability provides a breeding ground for corruption and selfinterested behavior on the part of the enforcer. ${ }^{362}$

Another problem with viewing community organizations solely in an enforcement role is that it myopically detracts attention from their legitimate and necessary informational role. Community organizations do play a crucial role in effective implementation of the CRA. Community groups are essential not to influence

${ }^{359}$ See supra text accompanying note 39 (noting that public disclosure of an institution's CRA report has been required since 1989).

${ }^{360}$ See H.R. CONF. REP. No. 222, 101 st Cong., Ist Sess. 460 (1989) (stating that the intent of the disclosure provisions "was to promote enforcement of CRA by allowing the public to know what regulatory agencies are telling depository institutions and what the community reinvestment records of particular depository institutions are"), reprinted in 1989 U.S.C.C.A.N. 499.

${ }^{361}$ See, e.g., Marsico, supra note 62, at 171-72 (stating that community groups have taken the lead in enforcement of the CRA).

${ }^{362}$ See Macey \& Miller, supra note 27, at 335-37 (discussing the self-interested behavior of certain activists). When a lending institution is challenged by an activist group, it will often yield to pressure and fund the project that is being promoted by that group. The result is an uneven approach to community development. Additionally, some political and community leaders may attempt to establish their own enterprise and then use their leverage under the CRA to force the depositing institution to treat them favorably. See id.

This is not to say that consumer pressure and disclosure cannot in certain instances be an effective means of ensuring compliance with the CRA and a valuable source of information. Rather, in the case of the CRA, focusing solely on the enforcement role of consumer activists threatens to supplant entirely enforcement of the law by a politically accountable governmental entity. If there is a problem with enforcement of the CRA, the answer is not merely to create a posse of consumer watchdogs but also to examine problems in the underlying law and the existing enforcement mechanism. 
otherwise recalcitrant financial institutions toward the good, as the enforcement model of consumer activism suggests, but rather because they serve a crucial informational function. First, community groups can reduce the cost of CRA compliance which would otherwise be borne by the institutions. Any particular institution covered by the CRA is effectively taxed in an amount equal to the cost of their CRA outreach efforts. Properly construed, this tax consists of the extra search costs incurred in attempting to identify creditworthy potential borrowers in the institution's community. Community groups often have superior knowledge or access to information about these borrowers and can perform part of the search function at no cost to the institutions, and at a lower cost than the institutions would themselves incur. ${ }^{363}$ Second, given the community group's superior knowledge of the community and its borrowers, as well as the financial institution and its products, the potential for actual lender and borrower interaction is increased, resulting in a corresponding increased potential for actual CRA loans to be made. Finally, community groups can perform a valuable educational function in the community, which increases the potential for actual results. For example, community groups might offer programs in debt education. In this sense, community groups and activists should principally function as an informational intermediary between banks, their community, and borrowers.

This informational perspective on the role of community groups illuminates the shortcomings of excessive focus on the enforcement paradigm of community activism. In their growing role of enforcers and watchdogs of the CRA, community groups avoid costs that normally would be borne by them. By shifting their information function largely back to the financial institution, the institution is left with higher search costs than otherwise would be incurred if community groups performed part of the CRA search function. While this point would need to be empirically verified, when the institution's higher search costs are added to the costs associated with the community group enforcement mechanism and the cost of the exorbitant commitments that community groups extract in the application process, ${ }^{364}$ the narrow use of community groups in the

${ }^{365}$ See, e.g., Gruben et al., supra note 26 , at 39 (discussing how some banks allow nonprofit community groups to perform the initial applicant screening for CRArelated loans and arguing that such an approach shifts search and monitoring costs to community groups). By hypothesis, community groups might have lower search costs because they are more familiar with the neighborhood. See id. at 40 .

${ }^{36-4}$ See supra text accompanying notes 168-75 (discussing expansive commitments 
CRA process might prove ultimately to have escalated dramatically the costs of implementing the Act.

Calls for reform do at times encourage the proper role of community groups. In December of 1993 regulators proposed to give CRA credit under the Lending Test to institutions that provided a second-look program for denied applications, with more credit for programs in which community groups participate, ${ }^{365}$ appropriately reflecting the value of the informational function of such groups. In addition, credit would have been given for adjustments for partnerships involved with community groups under the proposed Investment Test ${ }^{366}$ and Service Test. ${ }^{367}$ Finally, the December proposal to establish standards for the effect of a CRA rating in the application process ${ }^{368}$ effectively undercut the leverage that consumer groups previously enjoyed at the application stage. $^{369}$ In a complete reversal, the October 1994 proposals and the final rules eliminated these provisions and, concomitantly, implicitly returned to the consumer enforcement model. ${ }^{370}$ Until agencies summon the strength to withstand the pressure of community organizations to remain as enforcers (and only enforcers) of the Act, which they are apparently unwilling or unable to do at this time, the information function that such groups should perform will fail to reach its true effectiveness.

In sum, the new enforcement regulations dance around, but do not directly address, the problems of access and opportunity. While the antidiscrimination norm has been invigorated, the treatment of access comes up short. Results presumably are intended to reflect access. Reliance upon results is overbroad, and perhaps as, if not more, costly than the old regime. Moreover, results are subject to the erroneous interpretation as a mandate for forced lending, most

extracted from applicant institutions by community groups).

${ }^{365}$ See December 1993 Proposed Regulations, supra note 11, at 67,488 (to be codified at 12 C.F.R. $\$ 228.7(d)(1))$.

${ }^{366}$ See id. at 67,489 (to be codified at 12 C.F.R. $\$ 228.8(i)(1)$ ).

${ }^{367}$ See id. at 67,490 (to be codified at $\$ 228.9(c)(2)$ ).

${ }^{363}$ See supra note 215 (quoting the December proposal for weighting CRA ratings in the application process).

${ }^{369}$ See supra note 362 (discussing how activist community groups might improperly use their leverage under the CRA to force lending institutions to fund their pet projects).

${ }_{370}$ See 1994 Proposed Regulations, supra note 181, at 51,274 (to be codified at 12 C.F.R § 228.29) (indicating that a CRA rating will be only one of several factors taken into account in considering applications); Final Regulations, supra note 181 (to be codified at 12 C.F.R. $§ 228.29$ ). 
particularly by the consumer groups that have co-opted for themselves the role of monitors of institutional compliance with the Act.

\section{PROPOSALS FOR THE FUTURE}

The universal consensus is that we share the vision of community investment; the CRA should be one modest step toward that goal by creating access and opportunity. Properly construed, the Act is that limited, but dignifiedly so. If we are devoted to the idea of maintaining thriving communities, rather than of forcing all urban ills under the grand umbrella of the CRA, we should accept the limits on what the CRA can accomplish and then move on from there. This move will open several avenues of reform to both regulation of existing institutions and to other means of ensuring community investment. Rather than being empty rhetoric regarding enforcement of a statute that was intended to be-and is-a substantial nudge in the right direction, reforms of these types offer a greater potential toward ultimately ameliorating the problems previously lumped under the banner of the CRA.

\section{A. Interpreting The New Enforcement Regulations}

As discussed in the previous section, the new CRA enforcement regime is a positive step forward and a potentially dangerous step back from the underlying purpose of the Act. Initially, regulators have employed an efforts-based enforcement regime that rated an institution based upon its outreach efforts in its locality. ${ }^{371}$ Despite the criticisms of this regime, ${ }^{372}$ its underlying conceptual approach was fundamentally sound. As an initial matter, the effortsbased enforcement regime was most consistent with the legislative history of the CRA, particularly with the express congressional intent not to have the CRA devolve into a credit allocation statute. ${ }^{373}$ We should then be wary of the battle cry of "results" over "efforts" that drives the debate over the CRA. Certainly it is an essential concern that laws should lead to results, and that laws fulfill their purposes. Yet, with respect to the CRA, the express

${ }^{371}$ See supra text accompanying notes $134-45$ (discussing the standards used to measure compliance with the CRA).

${ }^{372}$ See supra notes 3-5 (discussing the general dissatisfaction with enforcement of the CRA).

${ }^{373}$ See supra notes 106-11 and accompanying text (discussing the concern that the CRA would lead to credit allocation, and congressional assurances to the contrary). 
rejection of credit allocation renders wholesale regulatory implementation of a results-based enforcement regime a dubious move.

Other than with regard to the heightened antidiscrimination norm, the move toward results might become an unfortunate step toward a government-run lending program that gradually might supersede the market for credit. Should this become the case, the nightmare foretold by Senator Morgan in the CRA floor debates ${ }^{374}$ will unfold. Accordingly, under the new results-based performance standards, institutions should be allotted a substantial amount of leeway in providing information concerning demand in their assessment areas and concerning safety and soundness issues to provide the context in which their results are to be assessed. ${ }^{375}$

Congress, of course, could amend the CRA to require results over efforts, and, in effect, overrule its opposition to credit allocation expressed in 1977. Such a move would be undesirable, and is fortunately unlikely. An aggressive results-based CRA simply will fail to accomplish what should be its long-term goals: increased access and opportunity in lending. A results-based CRA might offer a short-term remedy for isolated problems of equality of access and equality of opportunity. Forcing results, for example by requiring institutions to commit a specified sum toward inner-city lending, would give the recipients of loans access to capital and even greater opportunity of consideration than other similarly situated borrowers. From the short-term perspective, access and opportunity are at least superficially served. However, because the goals of the CRA are to create an environment of real equality of access and real equality of opportunity for those borrowers, settling for short-term results does not facilitate those goals effectively.

Some might question the wisdom of continuing to measure CRA compliance largely through efforts, since the enforcement standards in effect since enactment of the CRA in 1977 led to only modest results. The fact that efforts did not lead to ideal results, however, may be the consequence of factors wholly independent of institutional and regulatory shirking of CRA responsibilities. The CRA was never intended to be a cure for every modern woe. The lack of consensus over what the CRA was intended to accomplish, and

${ }^{374}$ See supra text accompanying note 108 (expressing the fear that financial institutions may be forced to make unsound loans in a particular location in order to meet a quota of loans in that locality).

${ }^{375}$ See supra text accompanying notes 241-43 (discussing subjective elements in CRA results-based standards). 
especially the misguided debate of localism and community, have impeded advances in the area of community lending. Acceptance of the nature of the CRA as a limited step toward equality, rather than a cure for every social ill, makes way for progress.

\section{B. Safe Harbors and Exemptions}

The issue of exempting institutions from the CRA or of providing "safe harbors" to particular institutions in the application process has been a significant feature in the debate over the new enforcement regulations. ${ }^{376}$ As we move toward measuring compliance by results, the pressure for exemptions and safe harbors is certain to intensify.

\section{Size- and Performance-Based Safe Harbors and Exemptions}

Institution size is one major theme in the debate over exemptions and safe harbors. For example, under the new regulations, smaller institutions, unless they otherwise elect, are evaluated under substantially less stringent compliance standards than larger institutions. ${ }^{377}$ In addition, a number of proposals to exempt smaller institutions from the CRA entirely have been introduced into Congress, although unsuccessfully to date. ${ }^{378}$ The principal

${ }^{376}$ See supra text accompanying notes 218-19 (discussing regulators' initial opposition to exemptions, but noting the proposal of certain apparent exemptions). A "safe harbor" arises when institutions that have complied with certain specified criteria receive favorable treatment, such as immunity from protests, at the application stage. "Exemptions," on the other hand, would exclude an institution from provisions otherwise applicable to it. For a general discussion of safe harbors in the context of the CRA, see Swire, supra note 62.

${ }^{377}$ See supra text accompanying notes 220-30 (discussing compliance tests for small institutions).

${ }^{378}$ See, e.g., H.R. 1362, 104th Cong., 1st Sess. \$ 122 (1995) (proposing an exemption for institutions with assets of less than $\$ 100$ million in communities of less than 30,000), available in LEXIS, Legis library, Bills file; H.R. 317, 104th Cong., 1st Sess. $\$ 810$ (1995) (proposing an exemption for institutions with assets of less than $\$ 100$ million in communities of less than 25,000), available in LEXIS, Legis library, Bills file; 138 Cong. Rec. H11,354 (1992) (daily ed. Oct. 5, 1992) (reporting the House proposal to exempt banks with less than $\$ 150$ million in assets and in communities of less than 30,000); 138 Cong. Rec. $S 9815$ (daily ed. July 2, 1992) (reporting the Senate bill to partially exempt from the CRA examination process institutions with no ECOA violations for the past five years, an outstanding or satisfactory CRA rating, assets of less than $\$ 100$ million, and located in communities of less than 20,000); 138 Cong. Rec. S7354 (daily ed. June 2, 1992) (reporting Senate bill to exempt from CRA examination process institutions with assets of less than $\$ 100$ million in communities of less than 20,000); 138 Cong. Rec. $\$ 4655$ (daily ed. Apr. 1, 1992) (reporting Senate bill to exempt from CRA examination process 
argument raised in favor of such size-based exemptions is based on the relative costs that smaller institutions bear in complying with the CRA. ${ }^{379}$ Community groups have argued in response to these claims for exemptions that smaller institutions receive many of the lower CRA ratings and that discrimination in rural areas served by smaller institutions is not uncommon. ${ }^{380}$

In some respects, some special treatment for smaller institutions is justified. Given the potential greater complexity of the new regulations and the new data reporting requirements, the cost factor has become an increasingly valid concern. The small institution performance standards are an economic necessity. In addition, the standards to which smaller institutions are nonetheless held ${ }^{381}$ adequately check any egregious behavior that might concern community groups. Objections to the more lenient evaluation procedures for smaller institutions are, therefore, hard to sustain.

The size of an institution, however, whether gauged by the size of the community served or the assets of the institution, should not

institutions with assets of less than $\$ 75$ million and half of their deposits in loans in communities of less than 15,000).

Provisions to exempt institutions from the CRA entirely must come through legislative amendment to the Act. Given the current text of the CRA, which applies to all regulated institutions, and its purpose to encourage all covered institutions to meet the credit needs of their communities, the existing legislation does not give regulators the authority to exempt classes of institutions from their mandated CRA activities.

${ }^{379}$ See, e.g., Foreman \& Brunson, supra note 3, at 40 (stating that small banks incur greater CRA compliance costs); Barbara A. Rehm, Activists Warn Banks that Campaign to Ease CRA Rules Might Backfire, AM. BANKER, June 29, 1992, at 1, 6 (noting that small banks claim they are "overburdened with paperwork"). Some evidence suggests that the complaints of smaller institutions might be exaggerated. For example, after receiving a "needs to improve" CRA rating, a small $\$ 56$ million-asset California institution embarked upon a "massive effort" to improve its rating. See Dean M. Nielsen, Top Rating a Team Effort for Bank of Commerce, AM. BANKER, July 7, 1993, at 8. Bank of Commerce implemented a written CRA program, engaged in extensive training of all employees including even janitors, and stepped up its outreach efforts in its community. See id. The program cost about $\$ 50,000$ to overhaul, but according to the president and chief executive of Commerce, "It's been a profitable program for the bank." Id. (quoting John Briner, president and Chief Executive of Bank of Commerce). The institution received an "outstanding" rating after implementing the program. See id.

${ }^{380}$ See Rehm, supra note 379, at 6 (discussing a community activist's belief that discrimination in rural areas "is a serious problem" and a general concern among activists that "current regulatory rules are not being adhered to or enforced"); see also supra note 147 (comparing ratings for smaller and larger institutions and finding that the former are lower).

see supra text accompanying notes 220-30 (discussing the proposed exemptions for small institutions). 
be a relevant consideration in exempting such institutions from the CRA entirely, as some proposals have suggested. Smaller institutions by their very nature are frequently best situated to provide access and opportunity. ${ }^{382}$ Accordingly, because a complete small institution exemption would directly contravene the underlying purposes of the CRA, small institutions should be subject to at least some CRA requirements.

The other general theme in proposals to amend the CRA is providing exemptions or safe harbors based upon an institution's past CRA performance. ${ }^{383}$ Regulators specifically rejected a total exemption when revising the enforcement regulations, citing both administrative and policy grounds. ${ }^{384}$

The agencies' perceptions that performance-based exemptions from the entire CRA constitute questionable policy are correct and support the rejection of legislative amendments to exempt "good" institutions from the CRA. Performance-based exemptions rely upon an underlying notion that institutions that have performed well in the past will continue to perform as well, even in the absence of any regulation. Little evidence, however, exists to support this assertion. Moreover, under the new enforcement standards, the possibility exists that institutions may "buy" a superior rating through purchase of results or by making substantial qualified investments under the Investment Test. Allowing an entire exemption from the Act would therefore allow an institution to buy its way entirely out of the Act, with the concomitant possibility of its service area not having access to credit in the future.

Performance-based exemptions from examination and performance-based advantages when an institution's CRA record becomes germane to the application process stand on a different footing from entire exemptions from the Act. Assume that an institution received an outstanding rating on its last two CRA exams. Leniency in the evaluation process does not seriously undermine access and opportunity as would entire exemptions from the Act. The institution is still subject to the Act, and any future noncompliance presumably would be detected in later exams. Similarly, preferences

${ }^{382}$ Smaller institutions may appear less imposing to consumer borrowers. In addition, the lack of bureaucracy and centralized control of credit decisions may tend to allow credit to be granted other than on standardized credit risk criteria.

${ }^{383}$ See, e.g., supra note 378 (citing an exemption proposal placing emphasis on past CRA performance).

384 See supra text accompanying notes 218-19 (noting regulators' initial opposition to exemptions from the CRA). 
based upon performance provide an incentive for institutions to step up their community outreach efforts. Whether the institution cynically "bought" its rating or is truly committed in some deeper sense to community-based lending should be irrelevant: the incentive to shirk is not significantly increased by preferential treatment, and the incentive to perform most likely would be increased. Consider, then, regulators' December 1993 proposal to give "outstanding" institutions a safe harbor in the application process. ${ }^{385}$ Given that the institution would still have been subject to the CRA irrespective of approval of the application, it is hard to see how such a safe harbor would be objectionable.

\section{Alternative Financial Institutions}

Because the GRA only covers a limited number of specific types of institutions, ${ }^{386}$ financial entities not subject to the CRA in effect have received an exemption from the Act. Regulated institutions therefore must bear the costs of the CRA while unregulated institutions escape the GRA tax. Institutions not currently regulated by the CRA have recently embarked upon a well-publicized effort to avoid becoming subject to the CRA. ${ }^{387}$ At the same time, because the limited scope of the CRA renders regulated institutions in a disadvantageous position vis-à-vis unregulated institutions, ${ }^{388}$ bankers have called for an increase in the scope of the CRA to encompass the entire financial services industry. ${ }^{389}$ If the CRA is here to stay, under this view everyone should bear the cost.

A commitment to access and opportunity compels a more functional analysis of the reasons for these types of exemptions. ${ }^{390}$

\$85 See supra note 215 (detailing the December 1993 proposal to weigh an institution's CRA rating in the application process).

${ }^{386}$ See supra note 34 (defining "regulated financial institutions," the institutions that are covered by the Act).

${ }^{387}$ See supra note 24 and accompanying text (noting lobbying efforts by institutions not currently subject to the CRA).

${ }^{388}$ See Macey \& Miller, supra note 27, at 312-13 (arguing that the CRA imposes a tax on banks and savings institutions, thereby weakening them in relation to other financial institutions).

${ }^{389}$ See BankAmerica's Arguments for Putting Nonbanks Under CRA, supra note 24, at 12 (noting BankAmerica chairman's view that the CRA should be extended to cover the entire financial services industry, partly because nonbanking services already benefit from banking regulations).

${ }^{390}$ Most frequently, claims for or against these types of exemptions are couched in terms of disinvestment, geographic base, government charter, or government insurance. See, e.g., Gullo, supra note 24 , at 4 (presenting the finance companies' argument 
If the form of institution is such that, as a matter of equality, access and opportunity should be ensured, then the regulation of those institutions under the CRA should be seriously considered. Take, for example, proposals to include credit unions within the CRA. The basic organizational form of credit unions highlights the improvidence of requiring them to comply with the CRA. In essence, credit unions are the ultimate "community reinvesters." Deposits are reinvested with members rather than with nondepositors. ${ }^{391}$ Therefore, with respect to credit unions, there is no justifiable reason supporting a duty to ensure access and opportunity to the geographic community at large. The institutional form of the credit union allows depositors to form their own community; imposing extracommunity obligations would only conflict with that function.

In contrast, strong arguments favor the inclusion of finance and mortgage companies within the CRA. Finance companies are substantially engaged in the extension of credit to the general public, such that the need to ensure access and opportunity through legislation like the CRA becomes more compelling in this case. The current exemption for mortgage companies presents an even more persuasive case for expanding the coverage of the CRA to encompass those entities. In addition to being a significant source of consumer credit, mortgage companies are heavily involved in the residential real estate finance market, thus supplying strong reasons for bringing those entities within the CRA. Recently, the Department of Housing and Urban Development (HUD) reiterated its commitment to the goal of "a decent home and a suitable living environment' for every American. "392 Ensuring access to acquisition finance for individual private home ownership, therefore, becomes not only a matter of credit policy, but also intersects with federal housing policy.

for not being regulated under the CRA: unlike banks, finance companies "do not accept deposits, borrow funds from the Federal Reserve, or have charters to serve communities"); Snigdha Prakash, Lenders up in Arms over OTS Proposal, AM. BANKER, July 26, 1994, at 10 (reporting mortgage companies' claim that the CRA was designed only for deposit institutions). These claims attempt to resurrect the ill-conceived localism-community debate.

${ }^{391}$ If the aim of the CRA is, as some have claimed, to mandate reinvestment, credit unions by their inherent nature have fulfilled that goal already. The goal under a reinvestment rationale for the CRA would be to transform all institutions into credit unions.

${ }_{992}$ PRIORITY: HOME! The Federal Plan to BREAK THE CyCle OF HOMELESSNESS 3 (1994). 
The mortgage company exemption is even more troubling in light of evidence which suggests that some of those institutions frequently avoid African-American neighborhoods. ${ }^{393}$ Although a recent agreement between the Mortgage Bankers Association of America (MBA) and HUD indicates some commitment on the part of mortgage bankers to take their responsibilities toward low- and moderate-income areas seriously, ${ }^{394}$ the HUD agreement should not be viewed as a substitute for regulation of mortgage bankers under the CRA. That one of the principal players in the housing finance industry could so easily shirk the CRA through what the MBA sanctimoniously calls "bold and innovative" efforts ${ }^{395}$ is astonishing. The mortgage bank exemption from the CRA is indefensible, and the CRA should be amended expeditiously to include within its scope mortgage banks, as well as finance companies.

\section{C. $C D C s$ and $C D F I s$}

Community development corporations (CDCs) and community development financial institutions (CDFIs) should play a crucial role in facilitating greater investment in local communities. A CDC or CDFI, roughly defined, is an institution that is devoted principally to community-development activities or to community-based lending and other financial services. ${ }^{396} \mathrm{CDCs}$ and CDFIs enhance equality of access and opportunity in a number of ways. First, from the standpoint of providing geographic and informational access, CDCs and CDFIs provide a mechanism through which search costs for

${ }^{993}$ See Ralph T. King, Jr., Some Mortgage Firms Neglect Black Areas More than Banks Do, Wall ST. J., Aug. 9, 1994, at A1, A6.

${ }^{994}$ See Mortgage Bankers Ass'n of Am., Mortgage Banking Industry Announces Fair Lending Agreement with Clinton Administration (Sept. 14, 1994) (news release, on file with author). Under the HUD/MBA agreement, the MBA agreed to encourage its members to step up their outreach efforts in minority and low-income areas as well as to develop self-testing programs to police discrimination. See id. at 1. The agreement sets forth a model "best practices" agreement designed to increase home ownership opportunities, check credit discrimination, and increase minority representation in the mortgage banking industry. See id. at 2. The MBA has agreed to support HUD in reaching voluntary agreements with individual MBA members. See $i d$. at 1.

${ }^{395} \mathrm{Id}$. at 1 .

${ }^{996}$ See The Community Development Banking and Financial Institutions Act of 1993: Hearing on H.R. 2666 Before the House Comm. on Banking, Finance and Urban Affairs, 103d Cong., 1st Sess. 9-11 (1993) (hearings on CDFI- and CDC-related legislation) [hereinafter $C D C$ House Hearings]. 
qualified borrowers in any particular area may be reduced. Assume, for example, that five separate financial institutions serve a particular community. Each of those institutions would be required to incur the costs of identifying potential borrowers in the area and of processing information related to those borrowers. If, however, the institutions were to pool their resources to establish a GDC or CDFI dedicated solely to information gathering and processing in the area, economic data suggest that each institution's costs would be reduced, as would each institution's risk exposure. ${ }^{397}$ Second, through continued contact with community borrowers, a GDC or CDFI reduces the possibility of invalid biases against borrowers affecting lending decisions. Given the greater ability of CDCs and CDFIs to gather information about borrowers, discrimination related to inability to gather information or imperfections in information about credit risk becomes less likely. Finally, CDCs and CDFIs present an investment opportunity for the altruistic investor, with minimal search costs. ${ }^{398}$

Accordingly, CDCs and CDFIs invaluably advance access to and opportunity in the market for financial services. Yet, in spite of their obvious value, regulation of CDCs and CDFIs has been less than satisfactory, if not misguided. Under the CRA, an institution's participation and investment in community development (CD) programs and $\mathrm{CDCs}^{399}$ are factors that only marginally bear on an

${ }^{397}$ See Gruben et al., supra note 26, at 39 ("Since these same individual institutions perform many other types of loan functions in-house, it is clear . . . that the establishment of such consortia serves the purposes of lowering per-institution costs of information and of spreading risk in a lending process where such costs and risks are relatively high.").

${ }^{398}$ See supra text accompanying note 296 (discussing the unlikelihood that many depositors would be altruistic in the sense that they would wish to deposit their funds in a socially-conscious financial intermediary).

${ }^{399}$ The new CRA regulations still require that all investments must be otherwise lawful investments for the institution, see Final Regulations, supra note 181 (to be codified at 12 C.F.R. $\$ 228.12(\mathrm{~s})$ ), which therefore warrants reexamination of the limits that other laws place on institutional investment in CDCs and CDFIs. The Office of the Comptroller of the Currency (OCC) developed a more expansive attitude toward insured institutions' investments in CDCs when it finalized a proposal to encourage national bank investment in CDCs and community development projects. See Community Development Corporation and Project Investments, 12 C.F.R. $\$ 24$ (1994). The OCC rule allows a national bank to make CDC and CD project investments of up to $5 \%$ of the bank's unimpaired capital and surplus at the time of investment, and with approval of the OCC, up to 10\%. See § 24.4(b). Smaller national banks (holding less than $\$ 250$ million in assets) may make specified CDC and CD project investments of up to $5 \%$ of capital without prior OCC approval, thus simplifying the process involved in the decision to make such investments. See 
institution's CRA rating. ${ }^{400}$ Thus, the CRA does not actively encourage insured institutions to invest in CDCs and CDFIs. ${ }^{401}$ Given their potential for creating an environment of access and opportunity, as well as for reducing the costs of complying with the CRA, encouraging the development of CDCs and CDFIs through the CRA warrants a much more aggressive policy than has previously been applied or proposed.

Apart from CRA enforcement, the seeming lack of a legislative and regulatory initiative toward encouraging traditional financial institutions' participation in CDCs and CDFIs is evidenced by the sharp debate that ensued following the Clinton administration's announcement of its community development bank initiative. ${ }^{402}$

$\$ 24.11(\mathrm{~b})(1)(\mathrm{iii})$. For larger institutions, investments of up to $2 \%$ of capital or $\$ 10$ million can be made without approval. See $\$ 24.11$ (b)(1)(ii).

${ }^{100}$ See supra notes 135 (listing the assessment factors that dictate an institution's CRA rating), 185 (discussing the factors involved in rating under the Lending Test), 195 (discussing the "qualified investments" relevant to assessment under the Investment Test), 201 (naming the relevant factors under the Service Test) and accompanying text.

${ }^{401}$ The Investment Test largely incorporates the new regime's treatment of investment in CDCs and CDFIs. See supra notes 195-98 and accompanying text (discussing the factors relevant to the Investment Test). All investments must first be lawful, highlighting the importance of expanding institutional powers to invest in CDCs, such as the new OCC rules attempt to do. Yet, for retail institutions, investments in CDCs are unjustifiably underweighted in the CRA evaluative process, given their value. The Lending Test gives only nominal recognition for CDC-related activities. See supra notes $185-94$ and accompanying text (describing the Lending Test). Yet, it constitutes a retail institution's primary rating. Actual investments under the Investment Test have the potential to raise the base rating of the Lending Test only marginally. Actual direct lending is thus encouraged over lending through CDCs or capital investments in CDCs, although investments in and lending through CDCs are, in many cases, equally as valuable as, if not more valuable than, direct lending, not to mention less costly in many circumstances.

Community organizations object to allowing institutions to meet their CRA obligations through investment rather than through direct lending. See Gary M. Swidler, Making the Community Reinvestment Act Work, 69 N.Y.U. L. Rev. 387, 412-13 \& n.194 (1994) (explaining objections that investment allows banks to avoid direct lending to local communities and that community organizations often cannot satisfy the full range of local community credit needs). Yet, these objections ignore the long-term benefits that such investments promise. Institutions certainly should not be able to shirk the CRA with nominal contributions to entities not actively engaged in local lending or development. Regulations, however, easily could be tailored to avoid such a result.

${ }^{102}$ See, e.g., CDC House Hearings, supra note 396, at $27-28$ (exchange between Representative Vento and Bob Nash, Under Secretary for Rural Development), 36-38 (exchange between Representatives Rush and Bob Nash). The initial bill advanced by the Clinton Administration was introduced as the Community Development Banking and Financial Institutions Act of 1993, H.R. 2666, 103d Cong., 1st Sess. (1993), reprinted in id., at 77-101. 
As recently enacted, the Community Development Banking and Financial Institutions Act of $1994^{403}$ provides CDFIs with fundmatching financial assistance to support creation of CDCs and to finance community development projects. ${ }^{404}$ The Act properly recognizes the barriers that existing traditional financial institutions face in attempting to serve the credit needs of underserved communities. Creation and support of specialized institutions to help serve those needs is therefore certainly a step in the right direction. As originally proposed, however, traditional financial institutions were inexplicably ineligible to receive funds under the program. ${ }^{405}$ Ultimately, the final bill did include these institutions. ${ }^{406}$ This inclusion was proper, given that, if community investment is the desired goal, few reasons exist to exclude institutions who wish to involve themselves toward that end from government support in that effort.

\section{Minority-Owned Institutions}

Finally, from the perspective of equality of access and equality of opportunity, encouraging the development of minority-owned financial institutions is fundamentally important. Yet, this goal has been largely ignored in the debate over the CRA. ${ }^{407}$ The current dialogue over the CRA presumes that, once properly regulated, the

${ }^{403}$ Pub. L. No. 103-325, §§ 101-158, 108 Stat. 2161 [hereinafter CDBFIA].

${ }^{404}$ See CDBFIA $\$ \S 108(\mathrm{~b})(1),(\mathrm{e})(1)$ (specifying authorized uses of financial assistance and conditions of receipt of fund-matching aid).

${ }^{405}$ Funding under the original bill was only available for CDFIs. Traditional insured financial institutions-those that did not have as their "primary mission" community development-did not qualify for CDFI status. See H.R. 2666, supra note 402, § 3(b), reprinted in CDC House Hearings, supra note 396, at 78-79, § 3(b). A holding company could qualify for CDFI status only if it and each of its subsidiaries met the criteria for a CDFI. See id.

Some raised concerns that inclusion of traditional lending institutions in any CDC or CDFI proposal would allow those institutions to evade their duties under the CRA. See CDC House Hearings, supra note 396, at 39 (statement of Sen. Watt). Yet, as long as no "double counting" occurs with an institution's CDBFIA activities and its CRA activities, it is hard to see why this concern should persist.

${ }^{406}$ See CDBFIA, § 103(6) (defining "community partner" as a "person . . . that provides loans, equity investments, or development services"); $\$ 114$ (describing financial incentives for depository institution participation); $\$ 121(\mathrm{a})(4)$ (reserving one-third of funding for depository institution incentives under $\$ 114$ ).

${ }^{407} \mathrm{~A}$ glimmer of recognition of the importance of investment in minority- and female-owned institutions can be seen in the 1991 and 1992 amendments to the CRA, which directed regulators to consider such investments in the evaluation process. See supra text accompanying notes $42-46$ (explaining the importance placed on contributions to predominantly minority- or female-owned institutions). 
existing majority-owned system of financial institutions can cure the problems lumped under the banner of the CRA. This vision bears some troublesome implications.

Many minority-owned institutions presumably do not suffer from the biases to which majority-owned institutions may be prone. Minority-owned institutions often have cheaper or more reliable access to information about borrowers in minority communities. Similarly, minority borrowers may, if only through perception, find greater potential for fair consideration in minority-owned institutions. ${ }^{408}$ Finally, discouraging minority-owned financial institutions and substituting majority-based institutions in their place provides a subtle, but impenetrable, barrier to the development of minority control of capital.

At present, there is a paucity of minority-owned institutions in the country. ${ }^{409}$ Minority-owned institutions face the task of attracting adequate capital from traditional sources, while maintaining their competitive position with majority-owned competitors. ${ }^{410}$ Unfortunately, the recent emphasis on enforcement of the CRA has discouraged the creation and sustenance of minority-owned institutions. Increased emphasis on majority-owned institutions' lending has created greater competition among existing minority institutions. ${ }^{41}$ A heavier CRA stick has impelled majority-owned banks to intrude aggressively into what is often the local market niche of many minority-owned banks and to co-opt the customer base of minority-owned institutions by offering more competitive

${ }^{108}$ See David R. Sands, Money, Power Dwell Together, WASH. TIMEs, Sept. 17, 1990, at Al ("It's always better if you have somebody across that desk who understands your basic problems, and you just don't get that when you're talking to a white loan officer ...." (quoting Edward Jones, a black real estate agent)).

${ }^{109}$ As of the end of 1992, there were 36 black-owned banks in the country, 6 female-owned banks, 26 Hispanic-owned banks, 32 Asian-owned banks, 4 NativeAmerican-owned banks, and two multiracial-owned banks. See Office Correspondence, Board of Governors of the Fed. Reserve Sys., Regarding Minority-Owned Banks (Mar. 29, 1993) (on file with author).

${ }^{110}$ See, e.g., Veronica Byrd, Black Bankers Seek Broader Market, N.Y. TimEs, Sept. 6, 1993, at 33 (discussing black-owned banks' efforts to "reach[] out for mainstream status'" (quoting Samuel L. Foggie, President of the National Banker's Association)); Franklin Smith, Black Bankers Undaunted by the Freedom Fiasco, AM. BANKER, July 11, 1991, at 8 (discussing reaction to failure of Freedom National Bank of New York, a bank controlled by a racial minority, and explaining that raising sufficient capital is the biggest obstacle facing minority-owned banks).

11 See, e.g., Nanine Alexander, Tough CRA Rules Hurting Minority Banks, U.S. BANKER, Sept. 1991, at 70 (stating that the CRA has "spurred larger mainstream banks to challenge the traditional markets of smaller minority-owned institutions"). 
products than minority-owned institutions are able to offer. ${ }^{412}$ At the same time, many minority banks receive poorer CRA ratings because of their narrow market niche. ${ }^{413}$

The new emphasis on direct lending by majority institutions is certain to exacerbate these problems. The Lending Test, which constitutes the principal grade for larger retail institutions, ${ }^{414}$ threatens to encourage further destruction of minority-owned institutions, rather than investment in and development of those institutions. Minority-owned institutions must compete directly with larger institutions seeking loans for consideration under the Lending Test. For example, larger institutions may have an incentive to actively seek loans that might otherwise have been made by minority-owned institutions. The CRA could better be employed to provide incentives for cooperative alliances between existing majority institutions and smaller minority institutions, or direct investment in minority institutions, for example, by giving greater weight to such activities under the Investment Test. Although such an approach deemphasizes actual lending, it would be far better than encouraging deadly competition, as the CRA's emphasis on actual lending may do. As it stands, what should be one key to the problem of credit discrimination-minority ownership of financial institutions-is being at least ignored, if not openly discarded.

\section{CONCLUSION}

Since its enactment in 1977, the CRA has generated intense and often bitter controversy. While all participants in the debate continually claim allegiance to the goals of the Act, disagreement over the extent to which the Act should intervene into the affairs of regulated institutions has stalled the effort to revitalize and strengthen our communities. The themes of community and localism have fueled the controversy. This Article has argued that arguments about localism and community are unproductive for assessing the proper scope of legal intervention to further the cause

${ }^{412}$ See id. at 70-71.

${ }^{413}$ See Robert B. Cox, Minority Banks Seen Lagging in CRA Arena, AM. BANKER, Aug. 20, 1993, at 1 (claiming that although they make more loans to minorities, minority banks "singl[e] out the richest segment of their communities to a greater degree than all other banks," resulting in lower CRA ratings); Terrence O'Hara, Calif.'s Asian Banks Feel the Sting of CRA, AM. BANKER, Dec. 21, 1993, at 6 (discussing poor ratings resulting from minority-owned banks' failure to serve all minorities, as opposed to a particular minority group).

${ }^{+14}$ See supra text accompanying notes $185-94$ (describing the Lending Test). 
of community reinvestment. Particularly given the ever-growing intensity of the social problems that the CRA was intended to help ameliorate, the misplaced dialogue of community and localism should be put aside.

This Article has argued that individual equality, rather than community or localism, provides the best justification for the CRA. Specifically, the CRA is a warranted legislative intervention that should ensure equality of access and opportunity in lending. Yet, the most recent attempt to invigorate the CRA threatens to move the CRA further along the wrong road. An efforts-based enforcement regime was effective in ensuring equality of access and opportunity. The political pressure on regulators to move the CRA toward measuring results rather than efforts not only indicates that we stand dangerously close to total governmental control of the market for credit, but also may construct a CRA that often slights, rather than embraces, equality.

Everyone agrees that there are problems with the CRA that need to be addressed. The solution to these problems will be found only through further dialogue concerning the potential that a commitment to equality has for addressing credit discrimination and lack of access to financial institutions. Equality not only provides a framework for enforcing the CRA, but also provides a template for developing other forms of government initiatives that will advance equality of access and opportunity. This Article has argued that, under equality, consideration should be given to limited safe harbors from the CRA evaluation process, to expanding the scope of the CRA to encompass institutions such as finance companies and mortgage companies, and to developing incentives for the growth of CDCs, CDFIs, and minority-owned financial institutions. Only then will we finally find ourselves on the road toward the vision that everyone shares and wants to attain. That we continue to grasp at creating a CRA that works without reference to equality indicates that we are far from that point. 
